\title{
Philippines: Financial Sector Assessment Program-IOSCO Objectives and Principles of Securities Regulation Assessment
}

This Financial Sector Assessment Program--IOSCO Objectives and Principles of Securities Regulation Assessment was prepared by a staff team of the International Monetary Fund and the World Bank as part of the Financial Sector Assessment Program for the Philippines. It is based on consultations with the authorities and other information available at the time it was completed on July 2002. The views expressed in this document are those of the staff team and do not necessarily reflect the views of the government of the Philippines or the Executive Boards of the IMF and the World Bank.

The policy of publication of staff reports and other documents by the IMF allows for the deletion of market-sensitive information.

To assist the IMF in evaluating the publication policy, reader comments are invited and may be sent by e-mail to publicationpolicy@imf.org.

Copies of this report are available to the public from

International Monetary Fund • Publication Services

700 19th Street, N.W. • Washington, D.C. 20431

Telephone: (202) 6237430 • Telefax: (202) 6237201

E-mail: publications@imf.org • Internet: http://www.imf.org

Price: $\$ 15.00$ a copy

\section{International Monetary Fund Washington, D.C.}


FinANCIAL SECTOR ASSESSMENT PROGRAM

PHILIPPINES

\section{IOSCO OBJECTIVES AND PRINCIPLES OF SECURITIES REGULATION}

JULY 2002 *

THE WORLD BANK

INTERNATIONAL MONETARY FUND

FinANCIAL SECTOR VicE PRESIDENCY

MONETARY AND FINANCIAL SYSTEMS DEPARTMENT

* The assessments were based on information gathered during missions that took place on October 8-23 and November 19-December 6, 2001. 


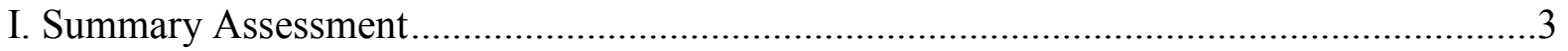

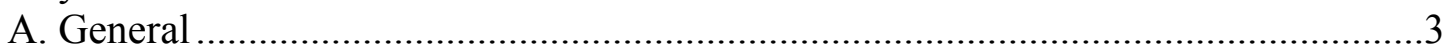

B. Institutional and Macroprudential Setting, Market Structure-Overview ................3

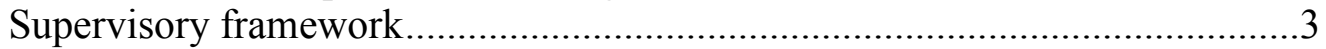

Market structure ................................................................................ 3

C. General Preconditions for Effective Securities Regulation....................................4

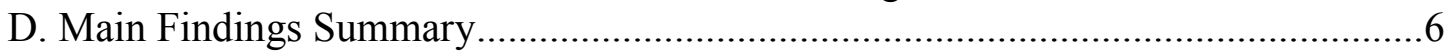

E. Authorities' Response and Recommended Next Steps.......................................

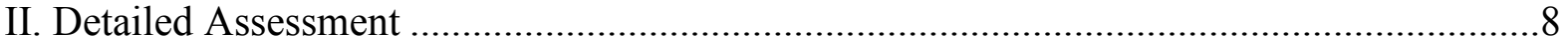

A. Information and Methodology Used for Assessment ........................................

B. Institutional and Macroprudential Setting, Market Structure-Overview ................9

Supervisory framework.................................................................

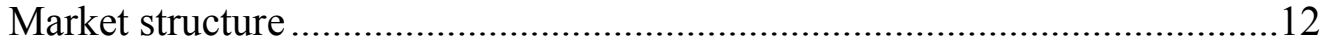

C. General Preconditions for Effective Securities Regulation................................. 13

D. Principal-by-Principle Assessment ............................................................ 15

III. Recommended Plan of Action and Supervisory Response to the Assessment.................50

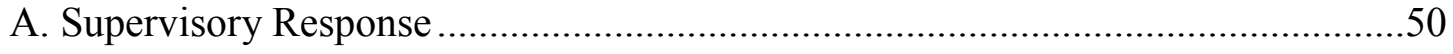

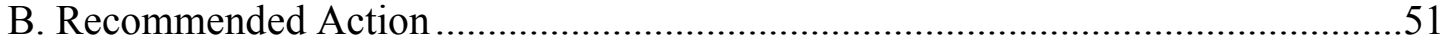

Text Tables

1. Summary of Main Findings of Assessment of Implementation of the IOSCO Objectives and Principles of Securities Regulation ....................................................................6

2. Detailed Assessment of Implementation of the IOSCO Objectives and Principles of Securities Regulation ................................................................................... 16

3. Compliance with the IOSCO Objectives and Principles of Securities Regulation.............47

4. Recommended Actions to Improve Compliance with the IOSCO Objectives and Principles of Securities Regulation 


\section{Summary ASSESSMent}

\section{A. General}

1. A joint World Bank/International Monetary Fund mission visited the Republic of the Philippines during the period October 8-23 and November 19-December 6, 2001 as part of the Financial Sector Assessment Program (FSAP). The aim was to assess the effectiveness of securities regulation, soundness of market intermediaries, and development prospects for the capital markets, including observance of the IOSCO Objectives and Principles of Securities Regulation. This IOSCO assessment was conducted by Noritaka Akamatsu, Lead Financial Economist of the World Bank.

\section{B. Institutional and Macroprudential Setting, Market Structure—Overview}

\section{Supervisory framework}

2. The SEC is the primary regulatory authority over the capital markets and their participants. The BSP also supervises NBFIs to the extent that they have ownership links with banks, and are permitted to have quasi-banking function and trust operations and offer foreign exchange products and services. The Securities Regulation Code (SRC) is the main legal basis for the regulation of the markets. The SRC narrowed and redefined the scope of responsibilities of the SEC to enable the regulator to focus on regulation of the securities market and its enforcement in particular. However, further rationalization of the scope seems necessary and is expected. The SRC also provided for demutualization of the Philippine Stock Exchange (PSE) which addressed, among other things, the PSE's conflicts of interest as an self-regulatory organization (SRO).

3. In addition to the SRC, the Corporation Code provides basic rules for establishment and governance of companies. There are also laws dedicated to governing each type of nonbank financial institutions (NBFIs) and universal banks participating in the market. Those include the Presidential Decree 129 on Investment Houses, the Financing Company Act of 1998 and the Investment Company Act of 1960. For each law, the SEC provides Implementing Rules and Regulations (IRR) to substantiate the laws with detailed provisions. Among the laws, the Investment Company Act is due to be amended, which is expected to bring investment advisers under the supervision by the SEC. The General Banking Law of 2000 and the BSP Manual of Regulations for NBFIs further provide rules for quasi-banking and trust functions of NBFIs and rules for universal banks and commercial banks to be engaged in the securities business and to own NBFIs subsidiaries. The BSP supervises NBFIs on the basis of this law and the regulations.

\section{Market structure}

4. The equity market is built around the Philippine Stock Exchange (PSE). It is supported by the Philippine Central Depository (PCD) and the Securities Clearing Corporation of the Philippines (SCCP) for clearance and settlement of trades. Key market 
intermediaries include: 44 Investment Houses 44, 174 Financing Companies, 176 BrokerDealer firms, 19 Mutual Funds and 15 Investment Management Companies. Of those, seven Investment Houses and seven Financing Companies can have a quasi-banking function which is defined by the General Banking Law as an ability to raise financing from more than 19 creditors. The Investment Houses are permitted to conduct underwriting of new issues of securities, thus required of a greater capital base (P300 million for Investment House as compared to P100 million for Broker Dealers). As of the end of September 2001, the total assets of the mutual funds amount to slightly less than P10 billion. Most of the NBFIs are owned or affiliated to commercial banks.

5. The PSE lists 231 companies and one series of Small Denomination Government bonds. The market capitalization at the end of August 2001 was P2,429 billion (US\$47 billion), representing nearly 80 percent of the GDP, a high figure for a country with per capita income of about US\$1,000. On the other hand, the annualized market turnover drastically declined to P173 billion (7.1 percent turnover) in 2001 from the peak of P781 billion (40 percent turnover) in 1999. Given the substantial level of capitalization, this represents low liquidity. An important attribute to the low liquidity is the small free float portion of corporate shares (about 15 percent) due to the holding of controlling shares by founding families of the companies.

6. The debt market is dominated by the government securities which are traded in the over-the-counter (OTC) market except for the one series of Small Denomination Bonds. The total capitalization of the government securities including those issued by government-owned and-controlled companies (GOCCs) and local government units (LGUs) stood at P1,128 billion, about 30 percent of GDP, as of July 2001. Of the amount, the national government debt amounted to P1,118 billion. 40 percent of the national government debt was in the form of treasury bills which generate most of the liquidity of the government securities (i.e., 40 percent turnover for all government securities and 90 percent for T-bills). Commercial papers (CPs) are the second most important instruments. While its capitalization (P35 billion as of October 15,2001 ) is very small as compared to the government securities, they are significantly more liquid (annual turnover ratio of 500 percent). Trading of government securities is dominated by commercial banks while investment houses seem to trade CPs actively.

\section{General Preconditions for Effective Securities Regulation}

7. Legislative bills currently being read in the congress is expected to address a need to rationalize taxation of financial instruments and services from various angles. In particular, elimination of Documentary Stamp Tax on the secondary market trading and securities lending and borrowing transactions is expected to have a significant positive impact on the market liquidity. The rationalization is also expected to provide more equal treatment and fairer market access for both domestic and foreign investors and market participants to stimulate competition. 
8. The SEC and the PSE are in the process of implementing the reforms mandated by the SRC. The SEC has restructured its organization and renewing its staffing with a focus on strengthening the enforcement capacity of the SEC. These new organizational changes and capacity building need to be reasonably completed before the SEC starts functioning at its full capacity under the SRC. The PSE also corporatized itself, reformed its board and is now due to go public to restructure its ownership structure. 


\section{Main Findings Summary}

\section{Table 1. Summary of Main Findings of Assessment of Implementation of the IOSCO Objectives and Principles of Securities Regulation}

\begin{tabular}{|c|c|}
\hline Subject & Main Findings \\
\hline Principles relating to the regulator, (CPs $1-5)$ & $\begin{array}{l}\text { Implemented. The SRC made the SEC a more enforcement- } \\
\text { oriented, operationally independent regulator with clear } \\
\text { objective and procedures. It has been better empowered to } \\
\text { enforce the law and given adequate budgetary resources } \\
\text { relative to the narrowed responsibilities. Computerization of } \\
\text { the data administration has recently achieved significant } \\
\text { progress. It needs to continue to work on enhancing } \\
\text { enforcement skills of the staff. Its accountability also can be } \\
\text { simplified and clarified. }\end{array}$ \\
\hline Principles of self-regulation (CPs 6-7) & $\begin{array}{l}\text { Partially [nearly] implemented. Against the SRC, the PSE } \\
\text { has been corporatized and its Board of Governors has been } \\
\text { reformed to become more independent of its member broker } \\
\text { dealers. The PSE now needs to go public to diversify away } \\
\text { from the excessive broker dealer dominance in ownership. It } \\
\text { needs to enhance its market surveillance system and Net } \\
\text { Capital reporting system. The PSE, together with the SEC, is } \\
\text { considering spinning out of its Compliance and Surveillance } \\
\text { Group to make it a dedicated self-regulator. }\end{array}$ \\
\hline $\begin{array}{l}\text { Principles for the enforcement of securities } \\
\text { regulation (CPs 8-10) }\end{array}$ & $\begin{array}{l}\text { Partially [nearly] implemented. The SRC provided } \\
\text { comprehensive inspection, investigation, surveillance and } \\
\text { enforcement powers for the SEC. The SEC needs to continue } \\
\text { to enhance the staff skill in using the comprehensive powers. } \\
\text { Its electronic information management capacity needs to be } \\
\text { further enhanced to avail more human resources for } \\
\text { enforcement activities while readily availing accurate, } \\
\text { updated information for inspection, investigation and } \\
\text { surveillance. }\end{array}$ \\
\hline $\begin{array}{l}\text { Principles for cooperation in regulation (CPs } \\
11-13)\end{array}$ & $\begin{array}{l}\text { Implemented. The SEC has authority to share public and } \\
\text { non-public information with both domestic and foreign } \\
\text { counterparts. The rules of confidentiality of information is } \\
\text { sound. It only needs to agree on MOUs with willing } \\
\text { counterparts. The Anti-Money Laundering Act (AMLA) also } \\
\text { facilitates to overcome obstacles created by the Bank Secrecy } \\
\text { Law. }\end{array}$ \\
\hline Principles for issuers (CPs 14-16) & $\begin{array}{l}\text { Implemented. The disclosure regime is up to a high } \\
\text { standards. The SEC still plays significant role to ensure that } \\
\text { minority shareholders' interest is protected. However, the } \\
\text { strong founder family ownerships generally make it a } \\
\text { difficult environment to defend interest of minority } \\
\text { shareholders. The SEC is committed to completing the } \\
\text { adoption of the International Accounting Standards by } 2005 \text {. }\end{array}$ \\
\hline $\begin{array}{l}\text { Principles for collective investment schemes } \\
\text { (CPs 17-20) }\end{array}$ & $\begin{array}{l}\text { Partially implemented. The existing Investment Company } \\
\text { Act, while providing core elements needed for CIS } \\
\text { regulation, is outdated and requires clarification and } \\
\text { rationalization for its various parts. In addition, it does not } \\
\text { accept foreigners as members of the boards of directors, }\end{array}$ \\
\hline
\end{tabular}




\begin{tabular}{|l|l|}
\hline \multirow{2}{*}{$\begin{array}{l}\text { Principles for market intermediaries (CPs 21- } \\
\text { 24) }\end{array}$} & $\begin{array}{l}\text { discouraging foreign investment. It also leaves investment } \\
\text { advisors unregulated. The passage of the Revised Investment } \\
\text { Company Act is awaited. }\end{array}$ \\
$\begin{array}{l}\text { Implemented. The eligibility criteria and procedures of } \\
\text { registration are clear and sound. Capital and other prudential } \\
\text { requirements are clearly established. Model Internal } \\
\text { Supervision, Control and Compliance Procedures as well as } \\
\text { SRC Rules are sound. The procedures to deal with failure of } \\
\text { market intermediaries are clearly established. The system to } \\
\text { monitor Net Capital may be computerized to achieve daily } \\
\text { monitoring. }\end{array}$ \\
\hline Principles for the secondary market (CPs 25- & $\begin{array}{l}\text { Partially implemented. The PSE is a highly autonomous } \\
\text { market operator. With the demutualization, it has become a } \\
\text { for-profit corporation which is self-regulating. At the same } \\
\text { time, the Fixed Income Exchange and/or the Commodity } \\
\text { Futures Exchange will likely be introduced soon. } \\
\text { Competition emerging among these markets may raise doubt } \\
\text { about credibility of their self-regulatory functions. The SEC } \\
\text { is encouraged to provide key benchmarks through the SRC } \\
\text { Rules and/or SEC Orders to show what it envisages as a } \\
\text { ground design of the Philippine capital markets in which } \\
\text { various exchanges can compete as a for-profit businesses. }\end{array}$ \\
\hline
\end{tabular}

\section{E. Authorities' Response and Recommended Next Steps}

9. Principles relating to the regulators (CPs1-5). The SEC shall intensify the in-house training of its staff to enhance their skills on market surveillance, investigation and enforcement. The full computerization of our data is also going on. The Manual of Operations and Procedures for its staff is being reviewed and revised for simplicity and clarity.

10. Principles of self-regulation (CPs 6-7). The listing of the PSE is the second phase of demutualization. The Board is only waiting for the right time to go public. In the meantime, to implement the provisions of the SRC on the 20 percent ownership cap of broker dealers, the SEC has directed the PSE to offer its shares to institutional investors and has likewise suggested the ADB and the IFC to consider taking a stake in the Exchange.

Discussions on ensuring the independence of the Compliance and Surveillance Group of the PSE (CSG-PSE) is being undertaken by the Market Regulation Department of the SEC.

Although the PSE-CSG has already been incorporated as separate entity from that the of the PSE, the PSE President has requested for the delay of the operationalization of the CSG-PSE as an independent SRO as the PSE tries to study ways of achieving full independence of the CSG while remaining part of the PSE organizational structure.

11. Principles for the enforcement of securities regulations (CPs 8-10). On April 16, 2002, the SEC has operationalized its on-line filing for the registration of companies. Thereafter, reportorial requirements shall be filed electronically. Even the net-capital requirements from broker dealers shall be electronically fined and analyzed by our MRD. 
12. Principles for cooperation in regulation (CPs 11-13). The SEC recently acquired a favorable endorsement from the Department of Foreign Affairs (DFA) to enter into MOU with its counterparts. It is currently finalizing an MOU with Indonesia's BAPEPAM. Similar agreements with other regulators are being considered.

13. Principles for issuers (CPs 14-16). The SEC has recently approved the Code of Corporate Governance which shall be "mandatory" for all corporations whose securities are registered or listed, corporations which are grantees of permits/licenses and secondary franchise from the SEC and public companies.

14. Principles for collective investment schemes (CPs 17-20). The SEC hopes that the Revised Investment Company Act will soon be passed into law by this year. While the SEC is ready to appear any time before Congressional hearings, it has no control of what the priority Bills and schedule of our lawmakers are.

15. Principles for market intermediaries (CPS 21-24). The system to monitor Net Capital of brokers dealers is now being prepared by our MIS in cooperation with our MRD. The SEC hopes before the end of the second quarter, a system for testing shall be ready.

16. Principles for the secondary market (CPs 25-30). With the establishment and operationalization of the Fixed Income Exchange (FIE) and the revival of the Futures Exchange, the FSAP mission raised concerns that competition emerging among markets may raise doubts about credibility of their self-regulatory functions. The mission has thus suggested that the SEC provide key benchmarks through Rules and/or Orders to define what its concept of Philippine capital markets is in an environment where various exchanges compete as for-profit businesses. The SEC shall take note of this suggestion and will see to it that the mission's concerns will be properly addressed.

\section{Detailed ASSESSMent}

\section{A. Information and Methodology Used for Assessment}

17. The analysis contained in this assessment is based on information collected through extensive hearings with the SEC, the BSP, the Bureau of Treasury (BOT), numerous market participants and institutions including the Philippine Stock Exchange (PSE), the Philippine Central Depository (PCD), the Securities Clearing Corporation of the Philippines (SCCP), industry associations including the Investment House Association of the Philippines (IHAP), Investment Company Association of the Philippines (ICAP) and the Securities Brokers and Dealers Association of the Philippines (SBDAP), the Bankers' Association of the Philippines (BAP), LGU Guarantee Corporation, the Philippine Rating Services and a number of other individual private financial institutions. In particular, the hearings with the SEC involved Chairperson, commissioners, directors, division chiefs and line officers who all impressively accommodated the demand for information, for which the assessor is grateful. 
18. The assessment was based on thorough reviews of relevant laws including amendments and corresponding rules and regulations of the SEC, the BSP and the SRO (currently only the PSE) against each of the 30 IOSCO Principles for Securities Regulation. To the extent possible, it also examined supervisory capacity and practices actually developed and adopted by the SEC, the BSP, the PSE and, in some cases, even their member firms to verify actual application of the laws and regulations and their enforcement. The assessment adopted the self-assessment methodologies developed by the IOSCO and made extensive use of the High Level Survey Questionnaire and the set of five Self-Assessment Methodologies developed by IOSCO. The SEC kindly provided thorough responses to all the detailed questions in the Methodologies as well as the Questionnaire and discussed with the assessor in length wherever clarification was needed.

19. As it is clear in the above, the SEC was the primary counterpart in conducting this assessment although the BSP and the PSE also participated. All the responses to the IOSCO Questionnaire and Methodologies were prepared by the SEC. To avoid duplication with the Basle Core Principles assessment which focuses on the framework of bank supervision and the BSP's supervisory capacity, this assessment focuses primarily on the regulatory capacity of the SEC and the PSE as far as the market authorities are concerned.

\section{B. Institutional and Macroprudential Setting, Market Structure—Overview}

\section{Supervisory framework}

20. The Philippines' regulatory and supervisory framework is, while comprehensive in coverage, complex. It is due to the fact that the financial industry and services are increasingly conglomerated and universalized with functional regulation while the regulatory authorities remain to be fragmented. The SEC is the primary regulatory authority over the capital markets and their participants. Nonbank financial institutions (NBFIs) are regulated and supervised by the SEC. However, the BSP also supervises many NBFIs because of: i) their close ownership links with banks, ii) quasi-banking function and trust operations permitted for some of them ${ }^{1}$ based on licenses by the BSP and iii) offer of financial products and services involving foreign exchange transactions. On the other hand, Universal Banks are also permitted, based on registration with the SEC, to undertake underwriting as well as brokerage and dealing of securities. Broadly, the SEC's regulation and supervision tend to emphasize investor protection and fair market conduct while those of the BSP tend to emphasize financial soundness of the intermediaries. Finally, the Philippine Stock Exchange

\footnotetext{
${ }^{1}$ Investment houses and financing companies may have quasi-banking functions subject to BSP licensing and supervision under the General Banking Law of 2000. License for trust functions can also be granted for NBFIs under the Law.
} 
(PSE) is working as a front line regulator of the market as an authorized self-regulatory organization $(\mathrm{SRO})^{2}$.

21. While the SEC has a long history since 1936, its powers and responsibilities have been redefined by the Securities Regulation Code (SRC) issued in July 2000. Executive Order No. 192 of January 7, 2000 transferred the SEC out of the Office of the President and brought it under the "administrative supervision" of the Department of Finance (DOF). ${ }^{3}$ Prior to the SRC, the SEC had a quasi-judiciary function to rule on intra-corporate disputes and corporate rehabilitation. The SRC (Section 5.2) transferred this function out of the SEC to court. With this narrowed scope of responsibilities, the SEC can now focus more on regulation and supervision of the securities market and its participants with a greater emphasis on enforcement. However, the scope of the SEC's responsibility still remains to be too broad firstly because the responsibility to register all corporations (publicly or privately held), partnerships and associations still remains with the SEC and secondly because the SEC is responsible for regulating and supervising a wide range of NBFIs including not only broker-dealers, investment houses and mutual funds but also financing companies, Pre-Need Plans, lending investors and others.

22. Currently, investment advisors are not regulated and supervised by the SEC except for the requirement of registration with the SEC as corporation. However, the Revised Investment Company Act of 2001 now being read in the Congress is expected to bring them under the authority of the SEC. On the other hand, Pre-Need Plans are, by the nature of the business, similar to an insurance company, and therefore, their regulatory and supervisory responsibility is expected to be transferred out of the SEC to the Insurance Commission of the DOF. The lending investors are also not securities market participants. While they are in large number (said to be 4,000 to 7,000), most of them are small single proprietorships and not registered as corporation nor as partnership with the SEC. Instead, they are registered with the Department of Trade and Industry (DTI). If some of them upgrade themselves to become financing companies, those will formally come under the supervision by the SEC.

23. The legal framework for the securities market and its participants is also complex because there is a separate law for each type of those NBFIs, and consists of the Securities Regulation Code July 2000 (SRC), the Corporation Code of May 1980, the Presidential Decree 129 on Investment Houses (PD 129), the Financing Company Act of 1998 and the Investment Company Act of 1960. For each of the laws, the SEC issued Implementing Rules

\footnotetext{
${ }^{2}$ While other industry bodies or market institutions such as the Investment Company Association of the Philippines (ICAP) and the Securities Clearing Corporation of the Philippines (SCCP) set code of conducts for the members, they are not (yet) formally recognized as SROs.

${ }^{3}$ i.e., the SEC is accountable to the DOF for its financial efficiency and operational effectiveness but free from the DOF's interference with day-to-day activities, as defined in the Administrative Code of 1987 (Section 38 , Chapter 7, Title III, Book IV).
} 
and Regulations (IRR) to substantiate the law with more specific details of standards, forms and procedures. ${ }^{4}$

24. The General Banking Law of 2000 and the BSP Manual of Regulations for NBFIs further provide, among other things, rules for quasi-banking and trust functions of NBFIs. They also provide rules for Universal Banks and Commercial Banks to be engaged in the securities business and to own NBFI subsidiaries including Investment Houses and Broker Dealers and empower the BSP to supervise them. To clarify roles of each regulator in regulating and supervising different types of financial institutions and business operations, the Memorandum of Agreement (MOA) was signed between the SEC and the BSP in June 2001. The MOA clarified each regulator's role not only between the regulators but also for the regulated. It proved to be helpful in avoiding confusions, overlaps and overlooked loopholes in the regulatory and supervisory process of the financial conglomerates and universal banks. Another important legislation passed by the Congress in October 2001 is Anti-Money Laundering Act. The SEC is preparing its IRR for the Act in consultation with the Anti-Money Laundering Council in which the BSP also participates. ${ }^{5}$

25. There are several legislative bills currently in reading in the Congress which are expected to provide important additional legal infrastructure for the capital markets. Those include House Bills on the revised Investment Company Act of 2001 (House Bill No. 2814), Securitization (House Bill No. 2759), Special Purpose Asset Vehicle (House Bill No. 3236 intended for off-loading non-performing assets of banks), Personal Equity and Retirement Account (PERA) (House Bill No. 1665) and Financial Sector Tax Reform Bill. In particular, the last has four components including: 1) introduction of Financial Institutions Tax (FIT) on banks and nonbanks, 2) introduction of Thin Capitalization Rule (TCR) or Maximum Debt Funding Percentage Rule, 3) rationalization of taxation of foreign currency deposit units (FCDUs) and 4) rationalization of the documentary stamp taxes (DST). Elimination of DST on secondary market trading and securities lending and borrowing transactions is expected to have a significant positive impact on liquidity of the securities market. For those lending investors which are not able to upgrade themselves to become financing companies, there is currently a Lending Company Act being considered as part of the Micro Finance Program, which, if promulgated, may transfer their supervisory responsibility out of the SEC to the DTI or local authorities.

\footnotetext{
${ }^{4}$ I.e., i) Implementing Rules and Regulations of the Securities Regulation Code; ii) SEC Circular No. 4, 2001 on Procedures in the Enforcement of the Corporation Code, iii) the SRC and other Existing Laws Implemented by the Commission; iv) Basic Rules and Regulations to Implement the Provisions of Presidential Decree No. 129; v) Rules and Regulations to Implement the Provisions of the Republic Act 8556 (i.e., the Financing Company Act); vi) New Rules on the Registration and Sale of Pre-Need Plans under Section 16 of the SRC.

5 The SEC's IRR for the Act is to be coordinated with its SRC Rule 30.2-6 on Supervision against SRC Article 30 on Transactions and Responsibility of Brokers and Dealers and the Model Internal Supervision and Control and Compliance Procedures to be adopted by broker-dealers, investment houses and universal banks.
} 


\section{Market structure}

26. Key market institutions include the Philippine Stock Exchange (PSE), the Philippine Central Depository (PCD) and the Securities Clearing Corporation of the Philippines (SCCP). Key market intermediaries include: Investment Houses (7:37), Financing Companies (7:167), Broker-Dealer firms (176), Mutual Funds (19) and Investment Management Companies (15). Of those, Investment Houses and Financing Companies can have a quasi-banking function which is defined by the General Banking Law as an ability to raise financing from more than 19 creditors. ${ }^{6}$ The numbers in the parentheses indicate numbers of licensed firms. For the Investment Houses and Financing Companies, the first numbers show those with a quasi-banking function and the second numbers, those without. A key difference between the Investment Houses and Broker Dealers is that the former is permitted to conduct underwriting of new issues of securities, thus required of a greater capital base (P300 million for Investment House as compared to P100 million for Broker Dealers). As of the end of September 2001, the total assets of the mutual funds amount to slightly less than P10 billion. It is also noteworthy that most of the NBFIs are owned or affiliated to commercial banks. In fact, some commercial banks have been licensed as Universal Banks under the Universal Banking Act. Theoretically, they are permitted to conduct securities business directly under their roof. However, most of them have so far chosen to do the business through subsidiary broker dealers and/or investment houses.

27. The PSE, which was created by a merger between the Manila Stock Exchange and the Makati Stock Exchange in 1994, lists 231 companies including one small and medium size company as of end August 2001. It also lists one series of Small Denomination Government Bonds. The total market capitalization as of end August 2001, not including the government bonds, stood at P2,429 billion (US\$47 billion) representing a slight decline since the end of 2000 but surpassing the pre-crisis peak of P2,122 billion in 1996. As of end 2000, the ratio of market capitalization to the GDP was 78.1 percent while its pre-crisis peak was 97.8 percent in 1996, indicating a quite significant size of the market for a country with per capita income of about US\$1,000. However, the annualized market turnover for 2001 has declined to P173 billion from the peak of P781 billion in 1999, reflecting a fragile recovery from the crisis. In terms of number of shares traded, the decline is more striking; i.e., annualized volume for 2001 has declined to 192 billion shares from the hay days of 2,274 billion shares in 1996. Because of this depressed market activities, the PCD and the SCCP (and to some extent the PSE), whose revenues depend significantly on the trading volume, are currently experiencing financial difficulties. The market turnover ratio for this year is only 7.1 percent while that for the year of recovery (i.e., 1999) was 40 percent. By any scale, the market is illiquid for a market with capitalization of about 80 percent of the country's GDP. An important attribute to this generally low liquidity despite the high capitalization is the small

\footnotetext{
${ }^{6}$ Instruments issued by a quasi bank which are sold to more than 19 creditors are considered "deposit substitutes" and are subject to the reserve requirement. Commercial papers (CPs) and even Treasury securities on repurchase agreements (repos) can be included among such instruments if sold to more than 19 investors/counterparties.
} 
free float portion of corporate shares (about 15 percent) due to the holding of controlling shares by founding families of the companies. ${ }^{7}$

28. The domestic debt market is dominated by the government securities which are traded in the over-the-counter (OTC) market with an exception of one series of Small Denomination Bonds listed on the PSE. As of end July 2001, the market capitalization, including that of debt issued by government owned and controlled companies (GOCCs) and local government units (LGUs), stood P1,128 billion, i.e., about 30 percent of the GDP. Of the amount, $\mathrm{P} 1,118$ billion is of the national government debt including government-guaranteed debt of GOCCs, LGUs, etc. It is likely to increase further due to the expected budget deficit of the government. The capitalization of commercial papers (CPs), the second most important debt instruments, stood at P35 billion as of October 15 this year and declined from P44 billion at end 2000. The decline was due to the depressed demand for credit by companies and businesses. However, the liquidity of the instruments is much higher as compared to that of the equity. The annual turnover ratio for the CPs is around 500 percent while the government securities is roughly 40 percent. The most of the turnover for the government securities is attributed to short-term T-bills which account for over 40 percent of the total capitalization of the domestic government securities and have an annual turnover ratio of about 90 percent. The trading of the government securities is dominated by commercial banks (said to be 7080 percent) while investment houses seem to trade CPs actively. Generally, the liquidity of the government securities is low compared to that of developed market which can surpass 10 times a year (i.e., over 1,000 percent annual turnover). In particular, long-term bonds including Treasury bonds are rarely traded.

\section{General Preconditions for Effective Securities Regulation}

29. Among the legislative bills currently in reading in the Congress, House Bill on the revised Investment Company Act of 2001 (House Bill No. 2814) is expected to allow foreign investors to have representation in the board of directors of mutual funds. On the other hand, the Financial Sector Tax Reform Bill, which is currently being read in the Congress, is expected to reduce or eliminate the privilege currently enjoyed by foreign banks through the introduction of Maximum Debt Funding Percentage Rule. These are intended to provide more equal treatment and fairer market access for both domestic and foreign investors and market participants.

30. The Financial Sector Tax Reform Bill has three additional components including: 1) introduction of Financial Institutions Tax (FIT) on banks and nonbanks, 2) rationalization of taxation of foreign currency deposit units (FCDUs) and 3) rationalization of the documentary stamp taxes (DST). In particular, elimination of DST on secondary market trading and securities lending and borrowing transactions is expected to have a significant positive impact on liquidity of the securities market. In addition, Securitization (House Bill No. 2759), Special Purpose Asset Vehicle (House Bill No. 3236 intended for off-loading

\footnotetext{
${ }^{7}$ This implicates existence of some corporate governance problems.
} 
non-performing assets of banks) and Personal Equity and Retirement Account (PERA) (House Bill No. 1665) also involve elements to rationalize taxation on creation of the new financial schemes, instruments and transactions. Passage of these bills are awaited to provide a more leveled playing field for market participants, eliminate impediments for transactions and trading and encourage liquidity in the market. $^{8}$

31. The SRC provided a basis for two important reforms to ensure effective securities regulation. One is the redefining of the SEC's regulatory responsibility and associated reorganization and capacity building efforts, and the other is the demutualization of the PSE. Firstly, the SRC transferred out from the SEC the quasi-judiciary function to rule on intracorporate disputes and corporate rehabilitation, which made the scope of the SEC's responsibility more manageable. Prior to the SRC, the SEC had this quasi-judiciary responsibility over not only publicly held companies abut all companies including privately held ones incorporated in the Philippines. The SEC was then heavily overburdened with this responsibility and could not devote adequate resources to supervision of the securities market and industry and enforcement of the securities regulation. ${ }^{9}$ In response to the narrowed responsibilities, the SEC fundamentally reorganized itself as of the end of 2000 as mandated by the SRC. However, it is still in the process of building its capacity to reorient itself to enforcement. For example, it has once almost halved the number of staff from 708 and is now trying to fill about 70 positions to bring up the number to the planned 428 . The staff also need to be trained to enhance their enforcement skills.

32. The SRC also provided three critical strengths to the SEC to facilitate the reorganization efforts. One is the enhanced salary standards to attract and retain highly qualified staff. Another is enhanced financial resources for the SEC to provide the salary and improve its management information systems (MIS). The other is the indemnification of the commissioners and staff from law suits in the bona fide discharge of their functions and powers. ${ }^{10}$ The enhanced salary standards seem to be already attracting good attention among qualified college graduates and financial and legal professionals. While the indemnification of the commissioners and staff will provide more confidence and security in enforcing the laws and regulations, the ongoing hiring effort is taking time due to the need to take best advantage of the interest of many qualified. These new organizational changes and capacity

\footnotetext{
${ }^{8}$ In addition to the bills and recently amended laws, the Memorandum of Agreement between the SEC and the BSP has clarified supervisory responsibilities of the SEC and the BSP in regulating and supervising universal banks and NBFIs which are members of financial conglomerates including banks and/or have quasi-banking functions and/or trust functions. The MOA not only filled loopholes and rationalized the responsibility sharing but also made those clearer to the regulated and thus effectuated the securities regulation.

${ }^{9}$ Introduction of an electronic filing system for registration of companies and public issues of securities is also currently studied to reduce the still heavy workload in the SEC related to companies so that it can further focus on other regulatory, supervisory and enforcement activities than processing of the documents.

${ }^{10}$ These measures to strengthen the SEC which are often politically difficult to adopt were made possible due largely to the strong public concerns about the investigation of the controversial price manipulation case of the Best World Resources (BW) Corporation.
} 
building need to be reasonably completed before the SEC starts functioning at its full capacity under the SRC.

33. The other important reform is the demutualization of the PSE. The PSE has been criticized for being a cozy club of member brokers at the expense of their client investors. Hence, in the wake of the BW scandal, the PSE's SRO license was once suspended by the SEC in March 2000. By the passage of SRC, the demutualization was made a requirement and a majority of directors of its board had to be non-brokers. The PSE implemented the demutualization and associated reform of its board in August last year and, by doing so successfully persuaded the SEC to restore its SRO status. However, the ownership of the PSE still remains 100 percent with the participating brokers, which leaves some doubt about the credibility of the PSE to act in the interest of investors rather than the brokers.

34. The concentration of the PSE's ownership in the participating brokers appears to be also affecting the business interest of the Securities Clearing Corporation of the Philippines (SCCP), which is a majority controlled subsidiary of the PSE. To ensure safe settlement, the SCCP needs to provide proper disciplines for the participating brokers to comply with the rules to control exposures and settlement. This includes imposition of appropriate penalties and/or sanctions when any participating broker defaults. The current concentration of the ownership appears to be making it difficult for the SCCP to act against the business interest of the participating brokers. Hence, diversification of the PSE's ownership by going public needs to be carried out as soon as possible as required by the SRC.

35. Finally, effective securities regulation requires investors well educated of their rights and ways to protect those. The investor base in the Philippines is still thin and understanding of the general public about the securities investment is very limited. Broadening the investor base is a challenging task because of the damage to the public image of the securities investment caused by the BW scandal. In addition, the thin free float portion of the listed equity makes it difficult to attract individual investors. The SEC and the PSE need to conduct an educational campaign to enhance investors understanding of securities investment, their rights in doing so, ways to protect those and means available for them to do so. At the same time, they also need to work on enhancing the corporate governance of listed companies which are currently predominantly owned and controlled by the founding families.

\section{Principal-by-Principle Assessment}

36. Section 2 of the SRC provides the State Policy as the objectives which the SRC is enacted to achieve. In comparison with the three objectives provided by the IOSCO, the State Policy objectives expressly include investor protection. One of the IOSCO objective of ensuring the market being fair, efficient and transparent is implicitly provided in the expression to eliminate or minimize fraudulent or manipulative devices and practices which create distortions in the free market. However, the third objective of IOSCO, the reduction of systemic risk, is not expressly recognized in the State Policy. Instead, the State Policy emphasizes promotion of development of the market and its role to achieve social equity. The explicit recognition of self-regulation in the State Policy is also noteworthy. Generally, 
these emphases and characteristics of the law are consistent with the actual regulatory standards and practices of the SEC.

\section{Table 2. Detailed Assessment of Implementation of the IOSCO Objectives and Principles of Securities Regulation}

\begin{tabular}{|c|c|}
\hline Principle 1. & The responsibilities of the regulator should be clear and objectively stated. \\
\hline Description & 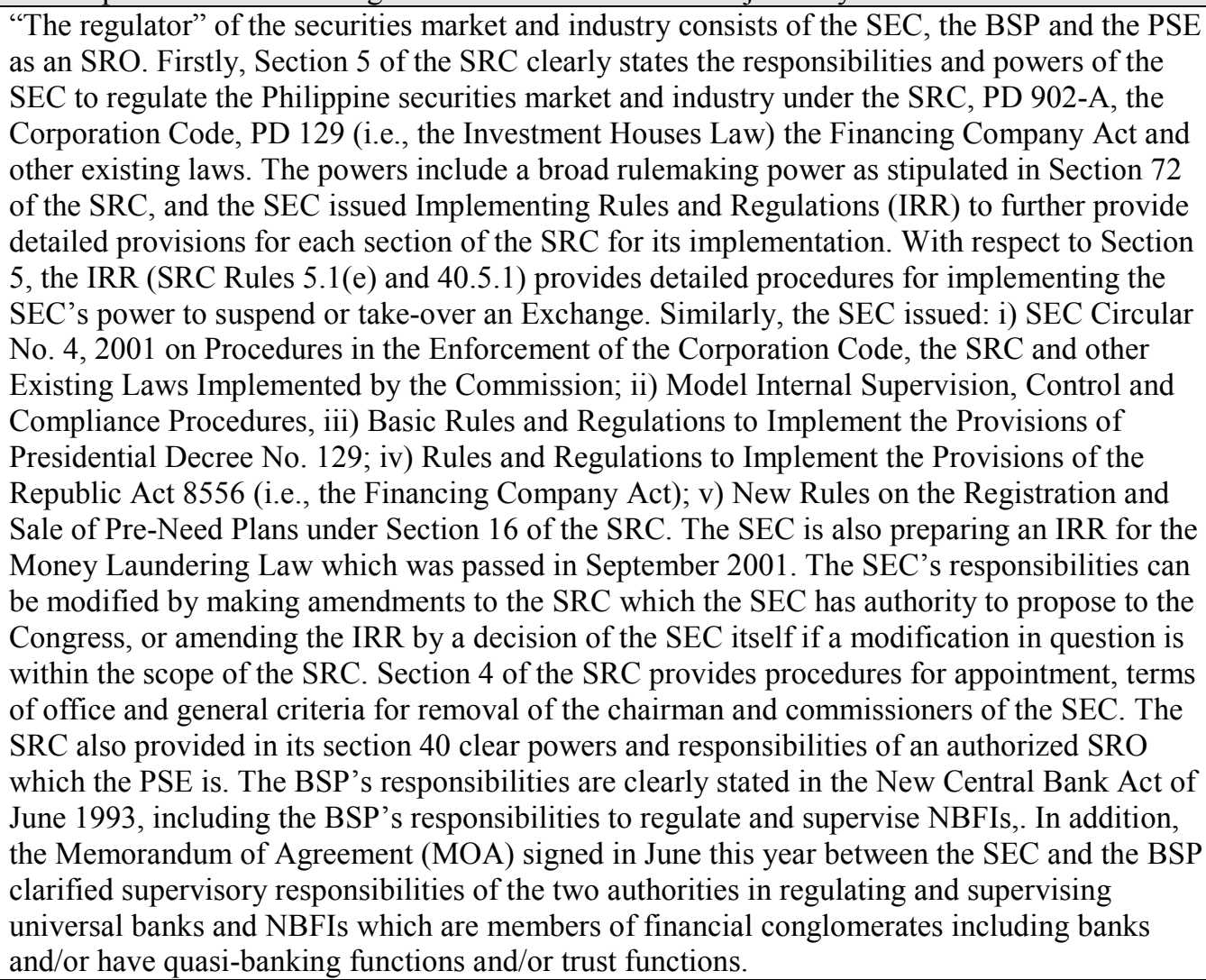 \\
\hline Assessment & Implemented \\
\hline Comments & $\begin{array}{l}\text { The Philippines' financial sector is complex and clarity of its regulations and responsible } \\
\text { authorities to the regulated is crucial in ensuring effectiveness of the regulation. The MOA } \\
\text { together with the SRC and the New Central Bank Act not only filled loopholes and rationalized } \\
\text { the responsibility sharing arrangements but also made those clearer to the regulated and thus } \\
\text { effectuated the securities regulation. The SEC's regulatory responsibility over Pre-Need Plans, } \\
\text { while clear under section } 16 \text { of the SRC and the supplementing IRR, may be transferred to the } \\
\text { Insurance Supervisory Commission, which is currently discussed in the Congress. The transfer } \\
\text { is considered because the nature of the business of Pre-Need Plans is more akin to insurance } \\
\text { companies, thus requiring a supervisory approach similar to that for insurance companies. The } \\
\text { transfer, if and when occurs, should further rationalize the responsibilities of the SEC. }\end{array}$ \\
\hline Principle 2. & $\begin{array}{l}\text { The regulator should be operationally independent and accountable in the exercise of its } \\
\text { functions and powers. }\end{array}$ \\
\hline Description & $\begin{array}{l}\text { Section } 4 \text { of the SRC charges the SEC as the Administrative Agency to put the SRC into } \\
\text { practice. By the Executive Order } 192 \text { issued in January 2000, the SEC was transferred from the } \\
\text { Office of the President to the Department of Finance (DOF) where the DOF assumes } \\
\text { "administrative supervision" of the SEC. Section } 38 \text { of the Administrative Code generally }\end{array}$ \\
\hline
\end{tabular}




\begin{tabular}{|c|c|}
\hline & $\begin{array}{l}\text { defines "administrative supervision" as a type of administrative relationship between a } \\
\text { department of the government and a regulatory agency(ies). Together, they stipulates that the } \\
\text { DOF generally oversee the operations of the SEC and insure that the SEC is managed } \\
\text { effectively, efficiently and economically but "without interference with day-to-day activities". } \\
\text { This principle of non-interference with day-to-day activities of the SEC has been actually } \\
\text { practiced by the DOF, which provides for operational independence of the SEC. Section } 6 \text { of } \\
\text { the SRC provides indemnification for the commissioners and staff of the SEC in the bona fide } \\
\text { discharge of their functions and powers, which supports operational independence of the SEC. } \\
\text { In particular, Section } 6.2 \text { provides for handling of confidential information, which is } \\
\text { supplemented by SRC Rule } 6.2 \text { on Rules of Conduct for Commissioners, Officers and } \\
\text { Employees. Section } 66 \text { also provides rules for disclosure of commercially sensitive information, } \\
\text { which are supplemented by SRC Rule } 66 \text {. Under the administrative supervision of the DOF, the } \\
\text { SEC is accountable to the DOF and may be required to submit reports and subject to } \\
\text { management audit, performance evaluation and inspection to determine compliance with } \\
\text { policies, standards, and guidelines of the DOF. In reality, however, the Commission of Audit } \\
\text { financially audits the SEC as it does for all government bodies and agencies on behalf of the } \\
\text { Congress. The Department of Budget and Management also holds the SEC financially } \\
\text { accountable, based on the audit by the Commission of Audit. The Congress, by its power to } \\
\text { summon the government bodies and agencies to hearing, call on the SEC also for hearing as a } \\
\text { need arises (e.g., a controversy, etc.) but at least once a year for a regular hearing. On the other } \\
\text { hand, the DOF is not exercising some of the key functions of the "administrative supervision" } \\
\text { as defined under the Administrative Code. Section } 70 \text { of the SRC provides that the judiciary } \\
\text { (the Court of Appeals) has a power to review the SEC's decisions based on a petition in } \\
\text { accordance with the Rules of Court. The SEC also issues annual report to the public although it } \\
\text { does not include a financial statement of the SEC. }\end{array}$ \\
\hline Assessment & Implemented \\
\hline Comments & 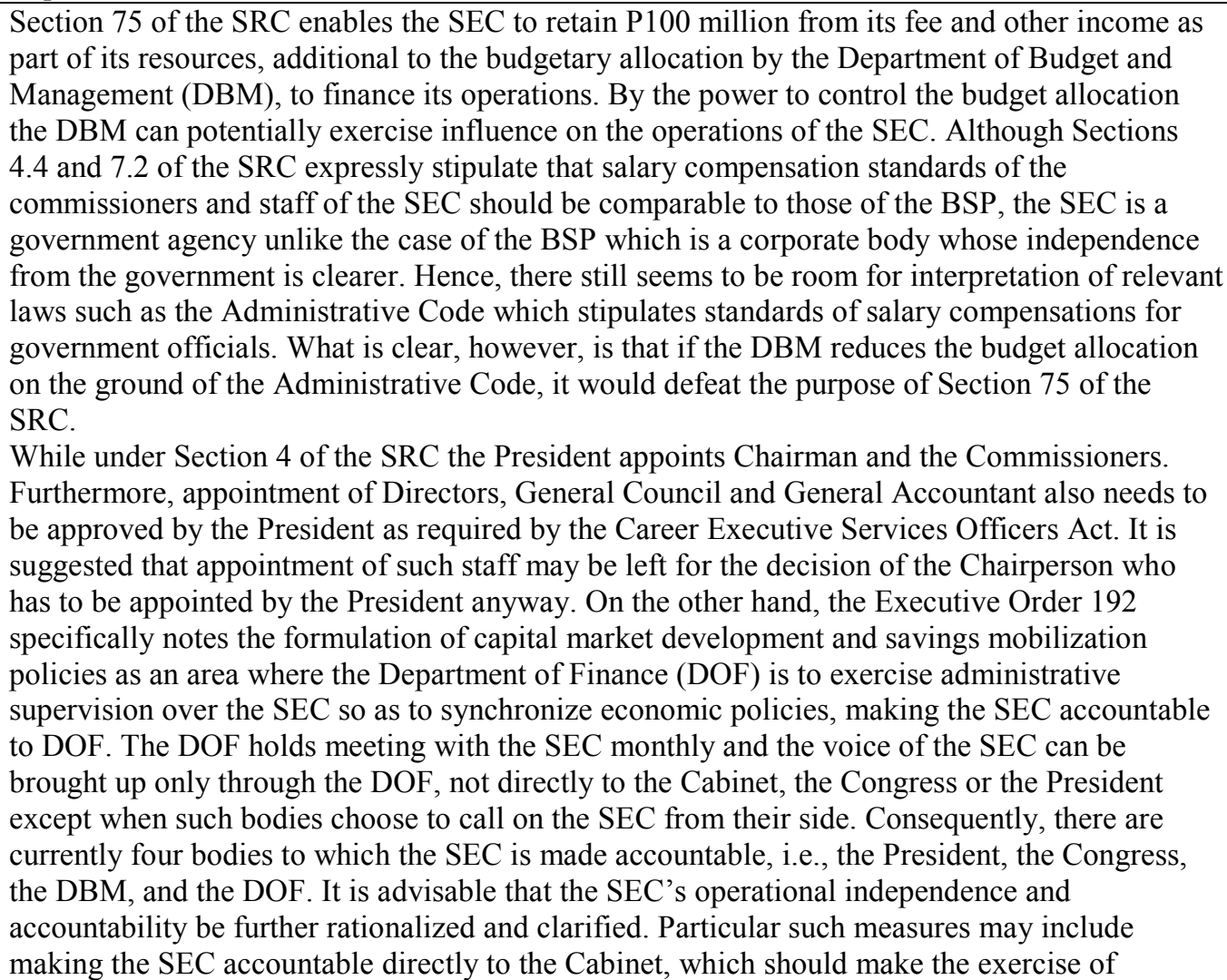 \\
\hline
\end{tabular}




\begin{tabular}{|c|c|}
\hline & fluence, if exists, more transparent and, therefore, can be avoided. \\
\hline Principle 3. & $\begin{array}{l}\text { The regulator should have adequate powers, proper resources and the capacity to perform its } \\
\text { functions and exercise its powers. }\end{array}$ \\
\hline Description & $\begin{array}{l}\text { Section } 5 \text { of the SRC provides adequate powers to the SEC, including authorization of market } \\
\text { participants (Section 5.1.c and m), direct surveillance of the market and market participants } \\
\text { (Section 5.1.e), ability to obtain information about the market, market participants, financial } \\
\text { products, customers and parties involved in securities transactions (Section 5.1.d, g and 1). The } \\
\text { SEC also has authority to communicate with other regulatory bodies (section 5.1.h). It has a } \\
\text { power to conduct investigation including criminal cases (Section 5.1.1) although the case needs } \\
\text { to be referred to the law enforcement authority and prosecuted by it. It has a power to impose } \\
\text { sanctions (Section 5.1.f) and intervene the market (Section 5.1.i). Section } 6 \text { indemnifies the } \\
\text { commissioners and staff in the good faith discharge of their functions and powers. Sections } 36 \text {, } \\
40 \text { an } 47 \text { also provide powers of the SEC specifically with respect to: a) exchanges and other } \\
\text { trading markets, b) SROs, and c) securities ownership. The SRC is also designed to provide } \\
\text { adequate resources for the SEC; i.e., Section } 75 \text { of the SRC provides that the SEC is authorized, } \\
\text { "in addition to its annual budget," to retain and utilize P100 million from its income (i.e., } \\
\text { registration fees, penalties imposed, etc.). As discussed in the comment for Principle } 2 \text { above, } \\
\text { however, implementation of this financing system remains to be tested over time. The SRC } \\
\text { reorganized the SEC to focus more on enforcement activities in the securities market and } \\
\text { industry rather than administration of corporate disputes and rehabilitation. This reorganization } \\
\text { calls for a shift in the required expertise mix which cannot be achieved over night. The SEC is } \\
\text { currently in the process to rebuild a new capacity and appropriate staff competency to meet the } \\
\text { need of the new organization. }\end{array}$ \\
\hline Assessment & Implemented \\
\hline Con & $\begin{array}{l}\text { A basis for the calculation of budget allocation for the SEC has been clarified and justified on } \\
\text { the basis of the new salaries of the commissioners and staff, which are made comparable to } \\
\text { those of the BSP (sections } 4 \text { and } 7 \text { ), and other fixed cost and depreciation of the assets. The } \\
\text { P100 million additional income retained can be used to build human and system capacity which } \\
\text { is critical to enhancing the competency of the SEC in the spirit of the SRC. } \\
\text { SEC-iRegister, an on-line electronic filing system for registration of companies, has recently } \\
\text { been introduced to reduce the burden of paper processing in the SEC. Thereafter, the on-line } \\
\text { electronic filing will be extended to other reports and disclosures to be filed to the SEC, thus } \\
\text { enabling the SEC to devote more resources to supervision and enforcement. The system may be } \\
\text { made self-sustainable by charging fees for use of the system by publicly held companies or PSE } \\
\text { listed companies which are required of stricter disclosure. The companies should actually be } \\
\text { saving otherwise required time, cost and efforts of documentary filing. } \\
\text { So far, staff training has been obtained in a rather ad hoc manner when some external } \\
\text { opportunities arise and when some bilateral aid was made available. Staff training in the } \\
\text { domestic market was obtained on an on-the-job basis from the market participants (particularly } \\
\text { for enforcement staff). Such efforts are useful and should be continued. At the same time, the } \\
\text { SEC has now bee secured of own resources to establish a more systematic in-house staff } \\
\text { training program. The premises of the SEC needs to be enhanced to meet basic safety } \\
\text { requirements such as a need of proper fire escapes, sprinklers, etc. and offer adequate security } \\
\text { for the computer systems. }\end{array}$ \\
\hline & 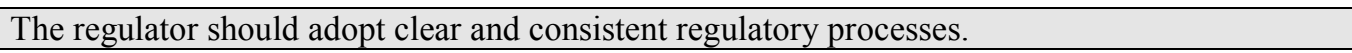 \\
\hline Description & $\begin{array}{l}\text { Empowered by Sections } 5(\mathrm{~g}) \text { and } 72 \text { of the SRC, the SEC issued IRR (i.e., SRC Rules) in } \\
\text { January } 2001 \text { which provided detailed standards, forms and procedures for the regulated to } \\
\text { adopt, file and follow to comply the SRC. General criteria for registration and authorization are } \\
\text { included the SRC and its IRR. The IRR also provide in its Annexes various forms to be filled } \\
\text { and filed with the SEC for registration and authorization purposes. Various sections of the SRC } \\
\text { and the SRC Rules and the other NBFI laws and corresponding rules issued by the SEC provide } \\
\text { circumstances under which applications for registration or authorization may be rejected or }\end{array}$ \\
\hline
\end{tabular}




\begin{tabular}{|c|c|}
\hline & 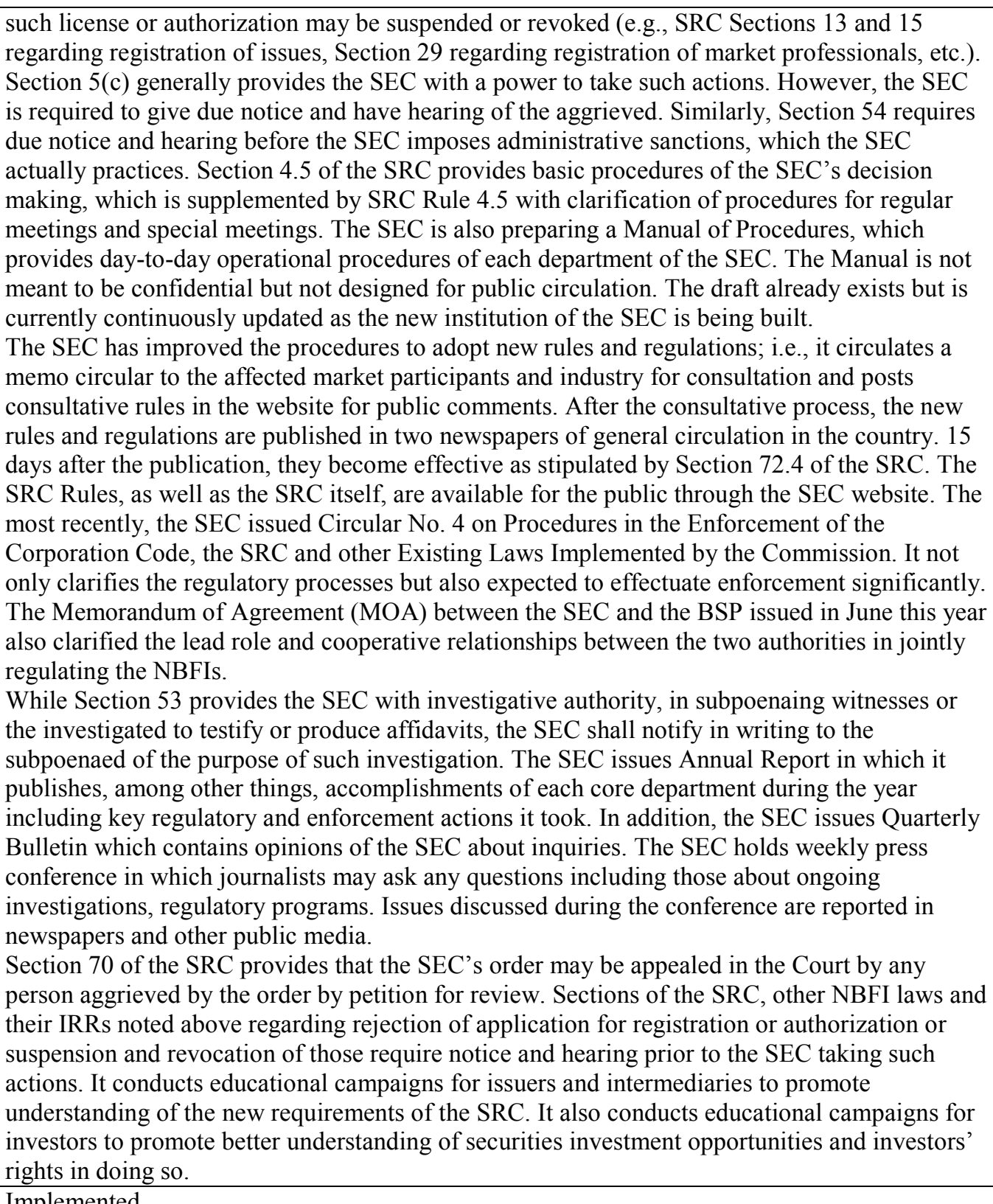 \\
\hline Assessment & 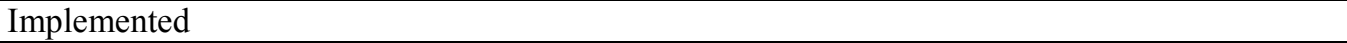 \\
\hline Comments & $\begin{array}{l}\text { The new procedures have been being established after the issuance of the SRC. Market } \\
\text { participants need to familiarize themselves with the SEC's regulatory processes for which the } \\
\text { SEC needs to continue to provide some education. The SEC is encouraged to disclose the } \\
\text { Manual of Procedures when completed if the information contained in it will be administrative } \\
\text { rather than strategic in nature. The procedures for industry and public consultation for the } \\
\text { purpose of adopting new rules and regulations may be more formally defined as part of the } \\
\text { Manual. Procedures for investigation and enforcement could contain confidential strategic } \\
\text { information depending on the way those are designed. The SEC is praised to disclose Circular } \\
\text { No. } 4 \text { on Procedures in the Enforcement since the nature of the information contained in it is } \\
\text { administrative, and its disclosure only enhances clarity of the operations of the SEC. } \\
\text { A process by which the regulations and supervisor procedures of Pre-Need Plans (against } \\
\text { section } 16 \text { of the SRC) were formulated by the SEC allegedly lacked some clarity. However, } \\
\text { appropriateness of the SEC's having regulatory authority over the Pre-Need Plans itself has }\end{array}$ \\
\hline
\end{tabular}




\begin{tabular}{|c|c|}
\hline & $\begin{array}{l}\text { been an issue of policy discussion in the government, and the regulatory authority is likely to be } \\
\text { transferred shortly to the Insurance Supervisory Commission. Not to be backward looking, this } \\
\text { specific case of regulatory processes with respect to the Pre-Need Plans is not factored in this } \\
\text { assessment. Lending Investors, which said to number } 6,000 \text {, are another group of financial } \\
\text { service entities for which the SEC is informally made responsible (with the promulgation of the } \\
\text { Central Bank Act, the responsibility to regulate NBFIs without quasi-banking functions, etc. } \\
\text { has been transferred to the SEC and lending investors were included among those transferred } \\
\text { under the SEC). However, there is no law to govern the business. In addition, they are small } \\
\text { single proprietorships which are not registered at the SEC. The SEC gave them an option to } \\
\text { transform themselves into Financing Companies through capitalization/merger and } \\
\text { corporatization. However, they are neither interested nor able to do so since it requires P10 } \\
\text { million capital in case of a Financing Company in Metro Manila. Currently, a Lending } \\
\text { Company Act bill is in reading in the Congress. When it passed, the responsibility to regulate } \\
\text { them may be transfer to the Department of Trade and Industry (DTI). }\end{array}$ \\
\hline Princ & $\begin{array}{l}\text { The staff of the regulator should observe the highest professional standards including } \\
\text { appropriate standards of confidentiality. }\end{array}$ \\
\hline Description & $\begin{array}{l}\text { SRC Rule } 6.2 \text { further provides the Rues of Conduct for Commissioners, Officers and } \\
\text { Employees. It provides detailed and comprehensive rules and procedures for avoidance of } \\
\text { conflict of interest including disclosure of financial interest. Staff in positions with discretionary } \\
\text { authority is particularly required to be free from "any" conflict of interest which is to help } \\
\text { ensure procedural fairness. Section } 66 \text { of the SRC provides basic rules for handling of } \\
\text { commercially sensitive information filed with the SEC. SRC Rule } 66.3 \text { further provides rules } \\
\text { for confidential treatment of such information filed with the SEC. Section } 66.5 \text { provides a basic } \\
\text { rule for disclosure of such information to a foreign enforcement authority for the purpose of } \\
\text { regulatory cooperation. } \\
\text { While Section } 6.1 \text { of the SRC indemnifies the commissioners and staff of the SEC in the bona } \\
\text { fide discharge of their functions and powers, Section } 6.2 \text { of the SRC holds them responsible for } \\
\text { negligence, abuse or acts of malfeasance or failure to exercise extraordinary diligence in the } \\
\text { performance of their duties. The judicial review of the SEC orders provided by Section } 70 \text { of } \\
\text { the SRC which enables any person aggrieved by an order of the SEC to appeal the order to the } \\
\text { Court should promote adherence of the commissioners and staff of the SEC to the Rules of } \\
\text { Conduct. There is no reported case of serious abuse or violation of this principle since the } \\
\text { enactment of the SRC. More generally, the commissioners and staff are subject to rules } \\
\text { stipulated in Chapter } 9 \text { General Principles Governing Public Officers of the Administrative } \\
\text { Code. The above rules of the SRC and the SRC Rules are made consistent with the provisions } \\
\text { of the Administrative Code but designed more specifically for the SEC commissioners and } \\
\text { staff. }\end{array}$ \\
\hline Assessment & Implemented \\
\hline Comments & $\begin{array}{l}\text { While the general rules of indemnification of the commissioners and staff or the SEC are clear, } \\
\text { some additional clarification might be useful specifically regarding their indemnification in } \\
\text { disclosing confidential or commercially sensitive information to other regulatory authorities for } \\
\text { the purpose of regulatory cooperation in case the disclosure leads to damages or losses to the } \\
\text { party which filed the information with the SEC and sues the SEC or its commissioner or staff } \\
\text { for the damage or losses. MOUs which the SEC is to agree upon with other regulators, domestic } \\
\text { or foreign, should also give appropriate reference to handling of such information by the } \\
\text { counterpart so as to control potential liabilities to the SEC. }\end{array}$ \\
\hline e 6. & $\begin{array}{l}\text { The regulatory regime should make appropriate use of Self-Regulatory Organizations (SROs) } \\
\text { that exercise some direct oversight responsibility for their respective areas of competence, and } \\
\text { to the extent appropriate to the size and complexity of the markets. }\end{array}$ \\
\hline Des & $\begin{array}{l}\text { Building a self-regulating market is part of the expressly stated objectives of the SRC. Section } \\
39 \text { of the SRC defines the role of SROs and types of organizations that can apply for an SRO } \\
\text { status. Currently, the PSE is the only formally recognized SRO under Section 39. In fact, the } \\
\text { registration requirements for an Exchange stipulated in section 33.1.a) of the SRC requires it to }\end{array}$ \\
\hline
\end{tabular}




\begin{tabular}{|c|c|}
\hline & 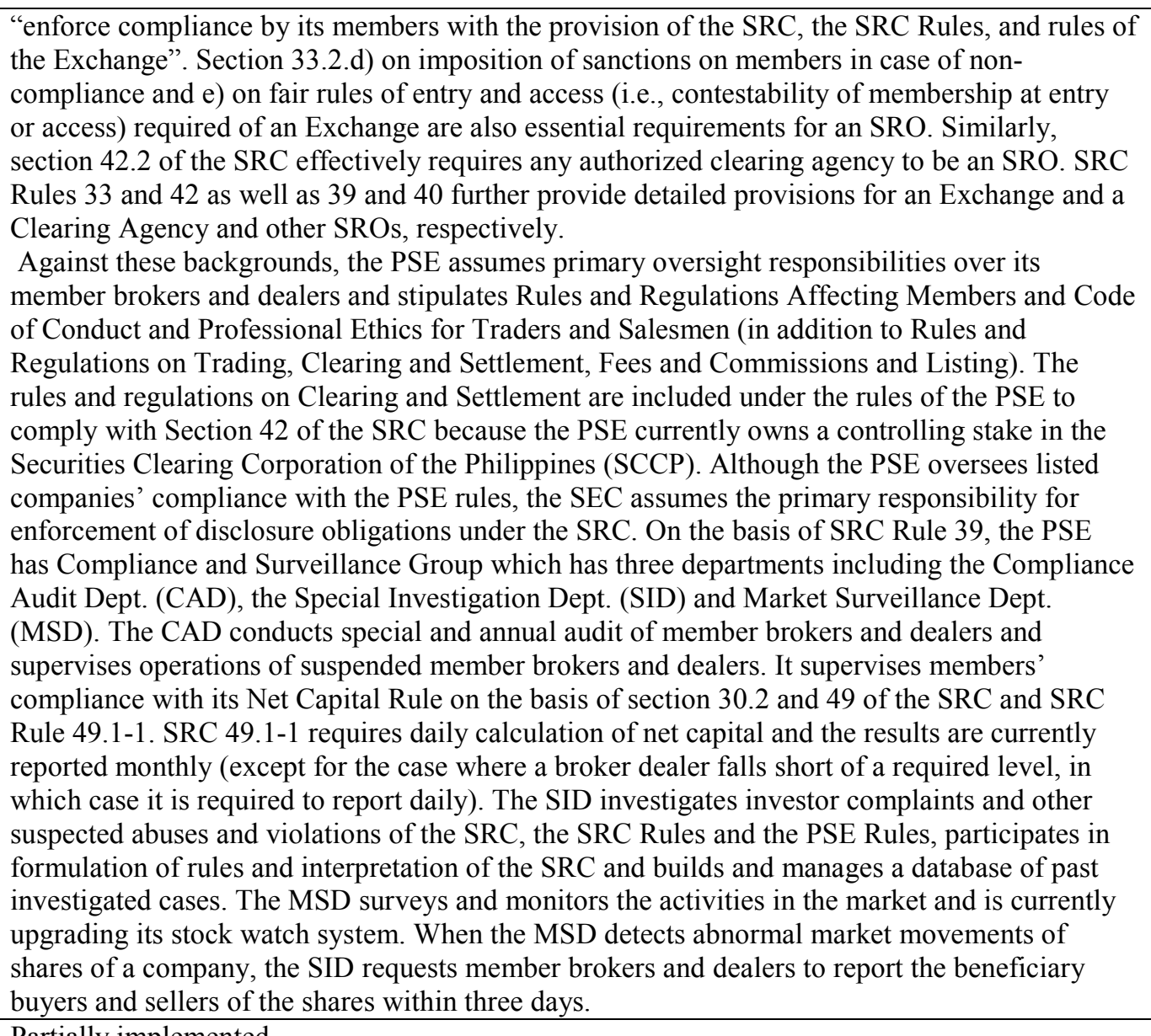 \\
\hline Assessment & Partially implemented \\
\hline Comments & $\begin{array}{l}\text { The PSE's SRO status was once suspended by the SEC in March } 2000 \text { due to alleged trading } \\
\text { irregularities arising from the BW scandal. There was then massive resignation of the staff of its } \\
\text { Compliance and Surveillance Group over protests on the investigation of the BW case. } \\
\text { Provisions of the SRC related to Exchanges and other SROs well reflect lessons learned from } \\
\text { this experience. Section } 33 \text { of the SRC included provisions requiring demutualization of the } \\
\text { PSE and associated restructuring of its governance mechanism from a variety of angles. The } \\
\text { new rules of governance required of the PSE is sound and, when fully implemented, should } \\
\text { significantly enhance the PSE's credibility as an SRO. In the current depressed market, the } \\
\text { broker dealers are fighting for survival, and it is certainly a difficult environment for the SRO to } \\
\text { impose penalties and sanctions on its member broker dealers. However, the SCCP is imposing } \\
\text { fines on broker dealers for failed trades. Those which are habitually erring in timely settlement } \\
\text { or found to be of high risk are referred by the SCCP to the PSE's Compliance and Surveillance } \\
\text { Group (CSG). The PSE in fact imposed a trading limit on the activity of the broker referred. } \\
\text { These actions by the PSE and the SCCP not only ensure safe settlement of the trades and } \\
\text { systemic stability of the market but also promote the enforcement culture. To ensure sound self- } \\
\text { regulatory motivation and proper incentives of the PSE and its members, implementation of } \\
\text { diversification of the PSE ownership is awaited. Separation of the CSG from the PSE to } \\
\text { become an independent SRO is also currently considered. The idea is similar to that of } \\
\text { separating NASD Regulation Inc. from the Nasdaq in the United States. Creation of a separate } \\
\text { SRO only for the PSE would be an expensive option for the small market. However, if it could } \\
\text { be combined with SRO functions required of the expected Fixed Income Exchange (FIE) and } \\
\text { the Commodity Futures Exchange (CFE)to create a super SRO for all exchanges, it may be } \\
\text { worthy of consideration. }\end{array}$ \\
\hline
\end{tabular}




\begin{tabular}{|c|c|}
\hline & $\begin{array}{l}\text { The CSG is working on enhancing its self-regulatory capability. The MSD tested and debug its } \\
\text { new automated market surveillance system. It corrected the arbitrary price band set for all } \\
\text { securities and now sets such for shares of each individual companies to detect abnormality in } \\
\text { share price movements. It was necessary because standard deviations in share price movements } \\
\text { significantly differed depending on the nature of underlying business. The new system has also } \\
\text { built in a tool to analyze the trading volumes, cross sales, trade concentration and accumulation } \\
\text { in conjunction with the price movements. The CAD hopes to increase the frequency of } \\
\text { reporting of net capital by the members. Some members, particularly large investment houses, } \\
\text { have electronic accounting and risk management capabilities and capable of reporting it daily if } \\
\text { required. However, many other smaller firms do not have such a capability. The CAD is } \\
\text { encouraged to explore jointly with the members ways to monitor net capital daily. Use of the } \\
\text { PCD's computation and account management capability by smaller brokers through } \\
\text { outsourcing may be useful to achieve it. The SID can also build and operate, jointly with the } \\
\text { members and the SEC, an interactive system to register profiles of individual licensed } \\
\text { professionals (similar to the Central Depository of Registry of the United States and } \\
\text { comparables systems of other countries). } \\
\text { Overall, the self-regulatory arrangements score well. The assessment should be changed to } \\
\text { "Implemented" as soon as the ownership diversification of the PSE is implemented. }\end{array}$ \\
\hline Principle 7. & $\begin{array}{l}\text { SROs should be subject to the oversight of the regulator and should observe standards of } \\
\text { fairness and confidentiality when exercising powers and delegated responsibilities. }\end{array}$ \\
\hline Description & $\begin{array}{l}\text { Section } 39 \text { provides the SEC with power to register, license and regulate an SRO and supervise, } \\
\text { examine, suspend or discontinue its operations. It provides requirements including certain } \\
\text { mechanisms of governance, fairly contestable membership, fair representation, fair treatment of } \\
\text { members, etc. that an applicant for an SRO status must satisfy and procedures of application. } \\
\text { SRC Rules } 39.1-1.11 \text { provides reporting requirements of an SRO to the SEC. SRC Rule 39.1- } \\
1.10 \text { provides rules based on which the SEC disciplines an SRO. The mechanisms of } \\
\text { governance required are a particular strength of the SRC and its Rules which are designed to } \\
\text { control conflict of interest, thus enhancing credibility of a registered SRO. Section } 40 \\
\text { empowers the SEC to supervise operations of registered SROs. Section } 40.3 \text { requires that rules } \\
\text { of an SRO or amendments to those be approved by the SEC. Section } 40.4 \text { empowers the SEC to } \\
\text { require an SRO to make specific changes to its rules. Section } 40.5 \text { empowers the SEC to } \\
\text { suspend or revoke an SRO status, expel a member of an SRO, or remove a director or an officer } \\
\text { of an SRO if it finds violation of SRC, its Rules or SRO rules. Section } 40.6 \text { provides that an } \\
\text { SRO is authorized to discipline or penalize its member (Section } 40.6 \text { ) and required to notify the } \\
\text { SEC of the action (Section } 40.7 \text { ). An aggrieved member may appeal to the SEC (Section } 40.7 \text { ). } \\
\text { Section } 40.6 \text { and } 7 \text { further provide fair and clear procedures of due notice and hearing of the } \\
\text { accused in the disciplinary procedures of an SRO and the SEC's role in overseeing the process. } \\
\text { Further, Section } 53 \text { of the SRC and SEC Circular No. } 4 \text {, 2001 provide that if the SEC } \\
\text { determines that the PSE is unable to adequately and effectively fulfill its enforcement duties, it } \\
\text { may order the PSE to provide it with all its investigative materials and take control of an } \\
\text { investigation. SRC Rule } 39.1-1.12 \text { provides that the SEC and SROs meet at least monthly to } \\
\text { discuss coordination of their regulatory and supervisory activities. The PSE's Rules and } \\
\text { Regulations, in particular its Chapter IV on Rules and Regulations Affecting Members, are } \\
\text { generally designed to be fair for all members. Section } 17 \text {, Article IX of Book V of the PSE } \\
\text { Rules provides for confidentiality of information. }\end{array}$ \\
\hline Assessment & Implemented \\
\hline Comments & $\begin{array}{l}\text { The SRC and its Rules are well elaborated with respect to the SEC's oversight of an SRO. The } \\
\text { PSE is currently reviewing its Rules and Regulations to have them consistent with the SRC and } \\
\text { SRC Rules. While the PSE as an SRO conducts routine and special audit on all its members, the } \\
\text { SEC not only reviews the audit reports submitted by the PSE but also conducts random } \\
\text { oversight audit on the brokers. The monthly meetings between the SEC and the PSE are } \\
\text { attended by SEC Chairman and/or commissioners and high level staff and all members of the } \\
\text { board of the PSE. The meeting discusses various issues in depth and make }\end{array}$ \\
\hline
\end{tabular}




\begin{tabular}{|c|c|}
\hline & 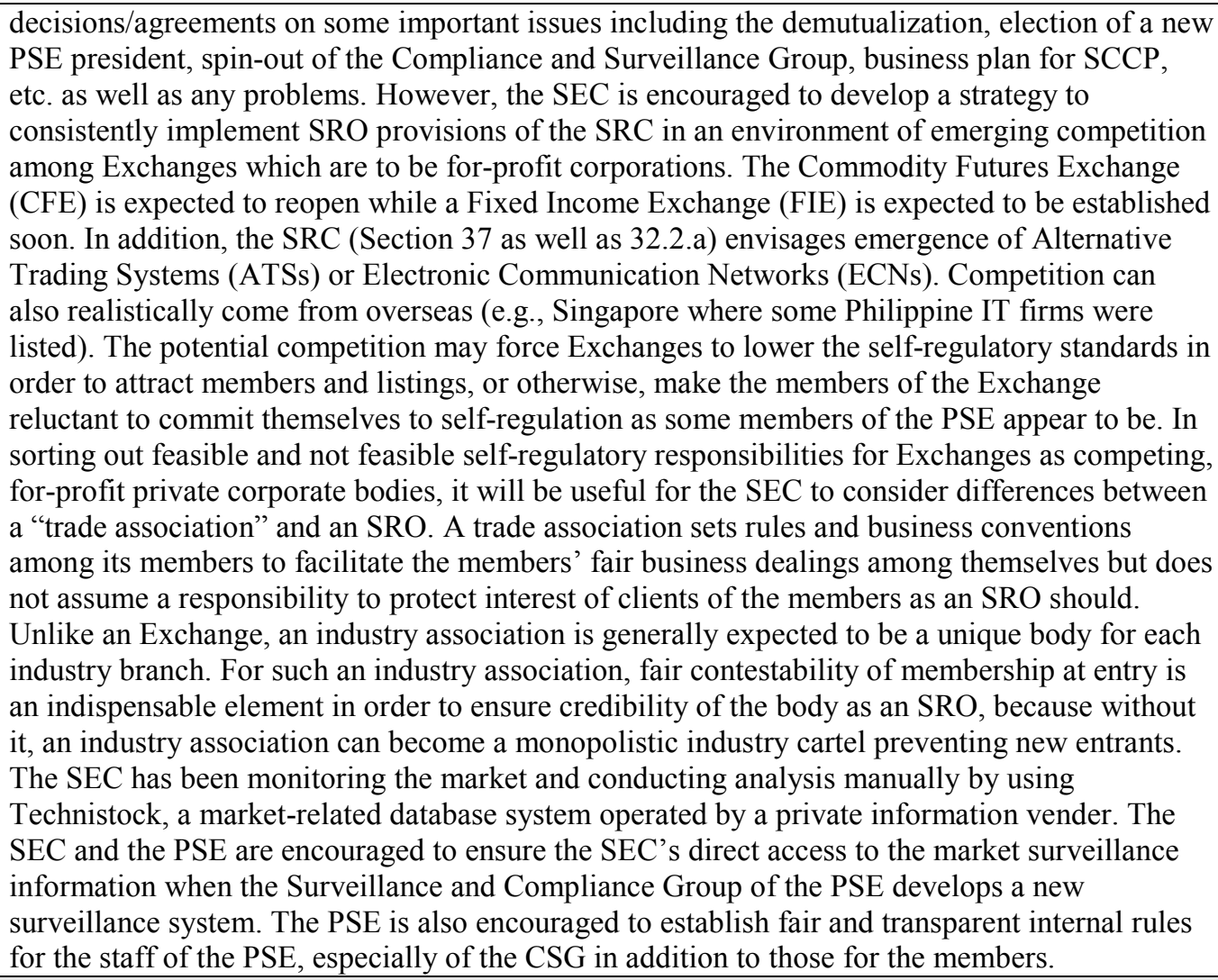 \\
\hline Principle 8. & The regulator should have comprehensive inspection, investigation and surveillance powers. \\
\hline Description & $\begin{array}{l}\text { Section } 5 \text { of the SRC generally provides the SEC with comprehensive powers including } \\
\text { inspection, investigation and surveillance of the market participants and markets. Section 5.(d) } \\
\text { generally provides the SEC with a power to regulate, investigate or supervise the activities of } \\
\text { persons to ensure compliance. Section 5.(e) empowers the SEC to supervise, monitor, suspend } \\
\text { or take over the activities of exchanges, clearing agencies and other SROs. Section } 53 \text { provides } \\
\text { that the SEC has discretionary authority to initiate and conduct investigation of any violation or } \\
\text { potential violation of the SRC, the IRR, SEC orders or SRO rules. Section } 52 \text { of the SRC and } \\
\text { corresponding SRC Rules require registered market participants to keep records of assets, } \\
\text { liabilities, transactions, contracts, etc. and avail those to inspection by the SEC. Section 5.(l) } \\
\text { empowers the SEC to issue subpoenas and summon witnesses to appear in any proceedings of } \\
\text { the SEC (including submission of affidavits) and in appropriate cases, order the examination, } \\
\text { search and seizure of all documents, papers, files and records, tax returns, and books of } \\
\text { accounts of "any entity or person" under investigation. Section } 53 \text { empowers the SEC to } \\
\text { conduct investigation at its discretion to protect investors. Other various sections of the SRC } \\
\text { and the SRC Rules provide respective details of the SEC powers. An exception to this rule is } \\
\text { books and records of banks which are protected under the Bank Secrecy Law. While there is the } \\
\text { Memorandum of Agreement (MOA) between the SEC and the BSP which enables the two } \\
\text { regulators to cooperate in inspection of NBFIs and their banks, the Bank Secrecy Law also } \\
\text { binds the BSP. The Anti-Money Laundering Law adopted in September this year now prohibits } \\
\text { anonymous accounts. Anti-Money Laundering Council, in which the SEC participates together } \\
\text { with the BSP and the Insurance Commission, has prepared IRR for the law. SRC Rule } 52.1-6 \\
\text { on Customer Account Information Rule permits numbered accounts without names of the } \\
\text { customers. However, the rule requires broker dealers to keep on file the names with a written } \\
\text { statement signed by the customer showing that the customer owns the account. The SEC can } \\
\text { verify "anytime" who the beneficiary owners are into the records of the brokers. The IRR may }\end{array}$ \\
\hline
\end{tabular}




\begin{tabular}{|c|c|}
\hline & $\begin{array}{l}\text { require some amendments to the SRC and its Rules. such as SRC Rule 30.2-6 on Supervision. } \\
\text { In fact, the Model Internal Supervision, Control and Compliance Procedures for broker dealers, } \\
\text { investment houses and banks engaged in broker dealer operations (issued in August 2001), } \\
\text { which substantiates the rule, already included procedures to detect and handle money } \\
\text { laundering in its Chapter III, Section H.4. }\end{array}$ \\
\hline Assessment & Implemented. \\
\hline Comments & $\begin{array}{l}\text { Overall, the SEC's powers to inspect and investigate are comprehensive and strong. The SEC's } \\
\text { on-going effort to upgrade its MIS capacity for electronic filing of records and surveillance of } \\
\text { the market should continue to enhance the effectiveness of the inspection and investigation. The } \\
\text { electronic filing system for companies (SEC-iRegister) has recently been launched. The PSE is } \\
\text { due to complete the to the upgrading of its surveillance and monitoring system. The SEC should } \\
\text { require the PSE to provide with a terminal to access the surveillance system. Currently, the SEC } \\
\text { has a trading terminal of MakTrade and manually analyze price and volume movements by } \\
\text { using Technistock, a market-related database system operated by a private information vendor. } \\
\text { Market intermediaries are working on enhancing their internal account management systems, } \\
\text { which should facilitate further enhancement of the SEC and the PSE's surveillance and } \\
\text { investigation activities. The Philippine Central Depository (PCD) is discussing with its } \\
\text { participants (including custodian banks) creation of sub-accounts, thus ensuring a name registry } \\
\text { within its system although it currently permits nominee accounts. The Philippine Association of } \\
\text { Stock Transfer Agents (PASTRA) is also working on its Automated Direct Registry (ADR) } \\
\text { system. These developments will further enhance the transparency of the market and } \\
\text { effectiveness of the inspection, investigation and surveillance by the SEC. }\end{array}$ \\
\hline Princ & The regulator should have comprehensive enforcement powers. \\
\hline Descr & $\begin{array}{l}\text { Section } 5 \text { of the SRC provides the SEC with comprehensive enforcement powers with respect } \\
\text { to all types of market participants and the market including those governed by the other NBFI } \\
\text { laws as well as the SRC itself. Section 5.(c) empowers the SEC to approve, reject, suspend, } \\
\text { revoke or require amendments to registration statements, and registration and licensing } \\
\text { applications. Section 5.(f) empowers it to impose sanctions for the violation of laws and the } \\
\text { rules, regulations and orders issued by it. Section 5.(g) provides the SEC with a power to issue, } \\
\text { approve, amend and repeal rules and regulations and supervise compliance with those. Section } \\
\text { 5.(i) provides the SEC with a power to issue cease-and-desist orders to prevent fraud or injury } \\
\text { to the investing public. Section } 64 \text { further provides the manner in which the SEC may issue } \\
\text { cease and desist orders In particular, the SEC can issue such an order "without a prior hearing", } \\
\text { if in its judgment after investigation or verification, the act or practice is or will be fraudulent or } \\
\text { cause grave or irreparable damages to the investing public. Section } 36 \text { provides powers of the } \\
\text { SEC specifically with respect to Exchanges and other trading markets including a power to } \\
\text { suspend trading. Section 5.(j) empowers the SEC to punish for contempt of the SEC. Under } \\
\text { Section 5.(k), the SEC can compel any registered company to call a general shareholders' } \\
\text { meeting under its supervision. Sections } 24 \text { to } 27 \text { defines and prohibits fraud, manipulation and } \\
\text { insider trading. Section } 54 \text { defines Administrative Sanctions, and Sections } 56 \text { to } 61 \text { define Civil } \\
\text { Liabilities in connection with: a) False Registration Statement, b) Prospectus, Communications } \\
\text { and Reports, c) Fraud in Securities Transactions, d) Manipulation of Securities Price, e) } \\
\text { Commodity Futures Contracts and Pre-need Plans, and f) Insider Trading. The Bank Secrecy } \\
\text { law requires a court order in order for the SEC to obtain bank records. However, the Anti- } \\
\text { Money Laundering Law now provides the SEC a power to freeze bank accounts which are } \\
\text { linked to securities transactions which are investigated. }\end{array}$ \\
\hline Assessment & Implemented \\
\hline Comments & $\begin{array}{l}\text { The Anti-Money Laundering Law provided an important addition to make the SEC's } \\
\text { enforcement power fully comprehensive. Further substantiation of the SEC's enforcement } \\
\text { powers is to be provided in IRR for the law which has been prepared by the SEC as well as the } \\
\text { BSP and the Insurance Commission for approval by the Congressional Oversight Committee. }\end{array}$ \\
\hline Principle 10. & $\begin{array}{l}\text { The regulatory system should ensure an effective and credible use of inspection, investigation, } \\
\text { surveillance and enforcement powers and implementation of an effective compliance program. }\end{array}$ \\
\hline
\end{tabular}




\begin{tabular}{|c|c|}
\hline Description & 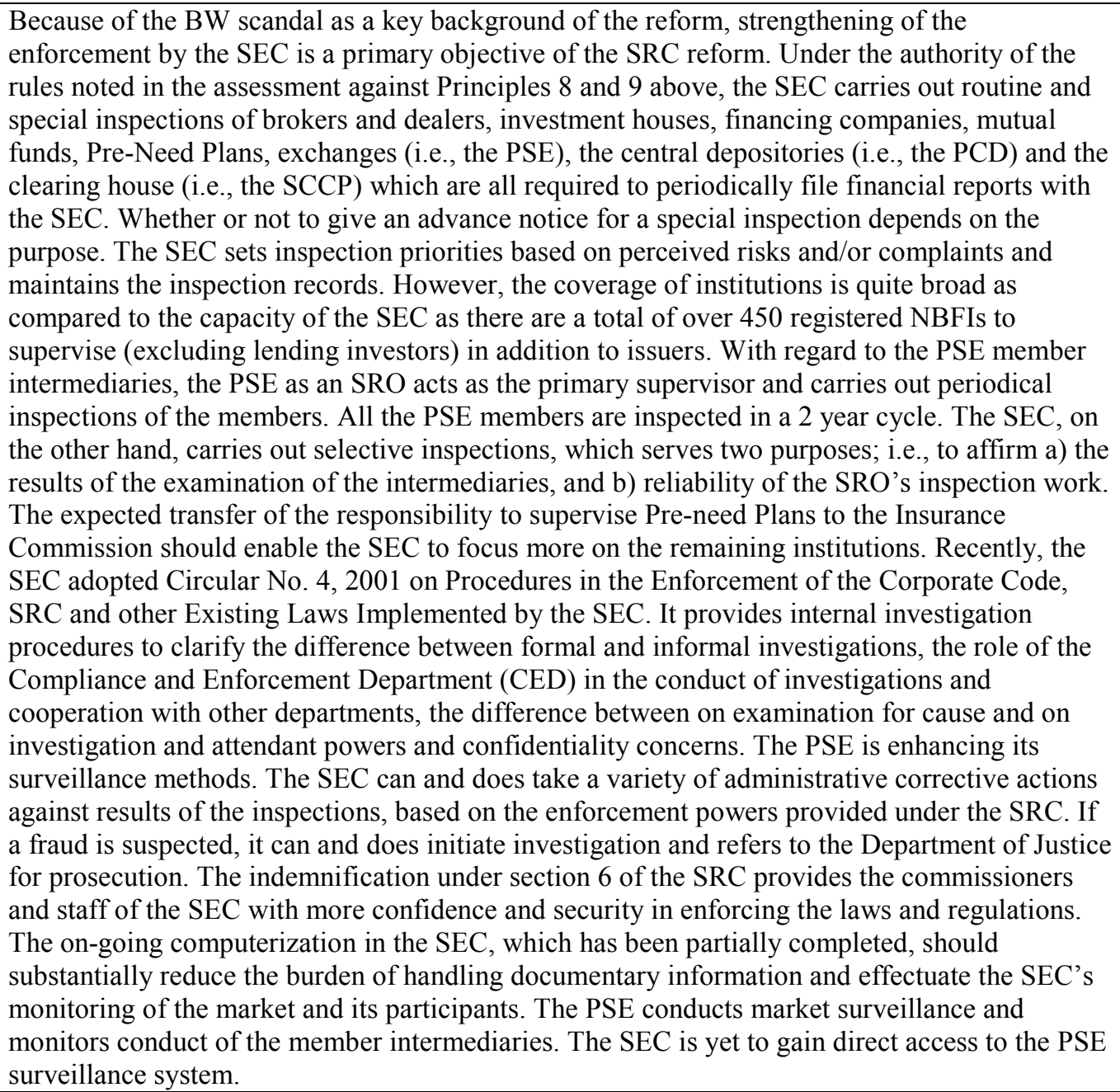 \\
\hline Assessment & Partially implemented \\
\hline Comments & $\begin{array}{l}\text { The progress with the on-line electronic filing of company registration is encouraging, and } \\
\text { further computerization for electronic filing of reports and disclosure documents is awaited. The } \\
\text { assurance of the extra budgetary allocation also will likely enable the SEC to create a } \\
\text { systematic in-house trading program to enhance skills of the staff in inspection, investigation } \\
\text { and enforcement. The inspection and investigation manuals and procedures developed with } \\
\text { assistance from international donor agencies will be useful in creating such an in-house training } \\
\text { program. While these developments and efforts indicate a good prospect for an "Implemented" } \\
\text { assessment in the foreseeable future, the SEC still experiences difficulties gathering sufficient } \\
\text { information with respect to violations where intent must be proven. The SEC finds particularly } \\
\text { difficult to prove intentional violations that involve conduct which may, on its face, appear to } \\
\text { comply with SEC/PSE rules, but clearly violates the spirit of the rules. This is a common } \\
\text { difficulty found in jurisdictions with a civil code legal tradition where forms of violations need } \\
\text { to be specified in the law. This provides loopholes for creative violator to work around. To } \\
\text { overcome it, a system of securities jurisprudence needs to be strengthened in the Philippines. } \\
\text { The SEC hopes to learn from other civil code jurisdictions and works with the PSE to draft } \\
\text { more comprehensive rules and issue more interpretative releases to clarify unethical conducts. } \\
\text { The SEC also needs to educate the public on market practices which constitute manipulation. } \\
\text { The SEC has successfully imposed fines in administrative procedures (e.g., } 21 \text { cease-and-desist } \\
\text { orders issued) and referred cases to the Department of Justice for criminal prosecution. } \\
\text { However, it is yet to successfully prosecute criminally a securities enforcement case although it }\end{array}$ \\
\hline
\end{tabular}




\begin{tabular}{|c|c|}
\hline & $\begin{array}{l}\text { has investigated many securities law violations (e.g., six suspected boiler room operations } \\
\text { involving officers of Mendez Prior, Dukes and Co. Inc., Evergreen, the Barclays Group, } \\
\text { Goldberg and Price Richardson Corp). The SEC forged a cooperation agreement with the } \\
\text { National Bureau of Investigation (NBI) in April this year to intensify the enforcement effort } \\
\text { against boiler room activities. The SEC also plans to work with two international donor } \\
\text { agencies to gain hands-on assistance in bringing successful enforcement actions and develop an } \\
\text { enforcement training program. }\end{array}$ \\
\hline Principle 11. & $\begin{array}{l}\text { The regulator should have authority to share both public and non-public information with } \\
\text { domestic and foreign counterparts. }\end{array}$ \\
\hline Description & $\begin{array}{l}\text { Section 5.(h) generally empowers the SEC to request or require assistance of enforcement } \\
\text { agencies of the government, civil or military as well as any private legal or natural person in the } \\
\text { implementation of its powers and functions. Section } 66 \text { defines commercially sensitive and non- } \\
\text { public information filed with the SEC, and its Section } 66.4 \text { prohibits disclosure of such } \\
\text { information. However, Section } 66.5 \text { empowers the SEC to provide assistance for any foreign } \\
\text { enforcement authority empowered to provide reciprocal assistance. The assistance includes the } \\
\text { disclosure of any information filed with or transmitted to the SEC if the requesting authority is } \\
\text { conducting a securities- or commodity-related investigation. The SEC can provide necessary } \\
\text { information regardless of whether an investigated matter constitutes a violation of the } \\
\text { Philippine law. The indemnity provided for the commissioners and staff under Section } 6.1 \text { of } \\
\text { the SRC applies only to the case of the good faith discharge of their official functions and } \\
\text { duties. Section } 6.2 \text { holds those who willfully violate the SRC or are guilty of negligence, abuse } \\
\text { or malfeasance in the performance of their duties liable for any loss or injury suffered by the } \\
\text { SEC or other institutions. The liability may be applied to cases of inappropriate disclosure of } \\
\text { confidential information including those involving conflict of interest. The SEC is a member of } \\
\text { the Inter-Agency Task Force including the BSP, the Bureau of Internal Revenue, and the } \\
\text { Department of Justice, which facilitates information sharing among the domestic agencies. } \\
\text { Congress recently passed the Anti-Money Laundering Act (AMLA) which enables the Anti- } \\
\text { Money Laundering Council (AMLC), in which the SEC participates together with the BSP and } \\
\text { the Insurance Commission, to freeze bank accounts related to suspicious securities transactions } \\
\text { or securities fraud. Suspicious securities transactions are required to be reported to the SEC } \\
\text { regardless of their size. Chairman of the SEC, who is a member of the AMLC, can then advise } \\
\text { the AMLC to freeze related bank accounts. }\end{array}$ \\
\hline & Implemented \\
\hline $\mathrm{Co1}$ & $\begin{array}{l}\text { The legal framework provides the SEC with clear and comprehensive authority to share } \\
\text { information with domestic and foreign regulators. The AMLA defines suspicious transactions } \\
\text { for the purpose of prohibiting money laundering. Its IRR issued by the AMLC requires reports } \\
\text { of suspicious transactions "regardless of the amount." The AMLA can provide protection for a } \\
\text { bank officer(s) against liabilities which could arise from the Bank Secrecy Law if he/she/they } \\
\text { disclose bank account information to the SEC. The SEC can share the information it gains with } \\
\text { a court order with other authorities without risking the commissioners and staff to be subject to } \\
\text { civil liabilities. Currently, the PCD's account structure identifies individual investor accounts } \\
\text { held by member broker dealers as nominees although identities of the investors are not } \\
\text { disclosed unless investigative needs arise. The PCD provides backoffice support for small } \\
\text { broker dealers which cannot afford to have own electronic account management systems. } \\
\text { Whether to require recording of identities of every investor in the PCD is currently under } \\
\text { consideration. }\end{array}$ \\
\hline 2. & $\begin{array}{l}\text { Regulators should establish information sharing mechanisms that set out when and how they } \\
\text { will share both public and non-public information with their domestic and foreign counterparts. }\end{array}$ \\
\hline Description & $\begin{array}{l}\text { The SEC signed with the BSP a Memorandum of Agreement to clarify each other's regulatory } \\
\text { responsibilities and lead role of each with respect to specific financial institutions, services and } \\
\text { circumstances such as ownership by banks in certain NBFIs. Through the MOA, loopholes and } \\
\text { overlaps have been filled and rationalized, and the regulated institutions now understand clearly } \\
\text { what they are expected to comply with by whom. The SEC is a member of an inter-agency task }\end{array}$ \\
\hline
\end{tabular}




\begin{tabular}{|c|c|}
\hline & $\begin{array}{l}\text { force including the BSP, Bureau of Internal Revenue and the Department of Justice which was } \\
\text { created to deal with the failures of five investment houses linked to banks. The task force } \\
\text { facilitates the SEC's information sharing with the other domestic agencies at the high level. The } \\
\text { Anti-Money Laundering Council (AMLC) consisting of Governor of the BSP and Chairmen of } \\
\text { the SEC and the Insurance Commission now provides a permanent place for the three financial } \\
\text { supervisory authorities to communicate and exchange information under the Anti-Money } \\
\text { Laundering Act (AMLA). The three authorities have jointly drafted the IRR for the AMLA. } \\
\text { Improvements needed are related primarily to the need to develop MOUs with foreign } \\
\text { regulators and other enforcement bodies. A model MOU had been drafted which is designed to } \\
\text { permit a wide range of assistance and cooperation subject to legal and regulatory restrictions of } \\
\text { each other's jurisdiction. It appears to permit assistance to be provided for purposes of, among } \\
\text { other things, detection of market manipulation and authorization of market participants and } \\
\text { professionals. The specific nature of assistance and/or cooperation is to be specified in a letter } \\
\text { of request. The SEC has recently received clearance from the Department of Foreign Affairs to } \\
\text { enter into an MOU with other regulatory agencies and is currently finalizing an MOU with the } \\
\text { BAPEPAM of Indonesia. }\end{array}$ \\
\hline Assessment & Partially implemented \\
\hline Comments & $\begin{array}{l}\text { Finalization of the MOU with BAPEPAM is awaited. The Taiwanese securities regulator } \\
\text { approached the SEC to agree on an MOU. It also seems important to agree on the same with the } \\
\text { Monetary Authority of Singapore since some Philippine companies have been listed and traded } \\
\text { in the stock exchange of Singapore. The SEC and the PSE also plan to clarify in writing (i.e., } \\
\text { MOU) how exactly the regulator and the SRO communicate (e.g., which individuals to } \\
\text { communicate for what) and cooperate in investigation. The assessment can be considered as } \\
\text { "Implemented" when the on-going efforts materialize. }\end{array}$ \\
\hline Prin & $\begin{array}{l}\text { The regulatory system should allow for assistance to be provided to foreign regulators who } \\
\text { need to make inquiries in the discharge of their functions and exercise of their powers. }\end{array}$ \\
\hline Desc & $\begin{array}{l}\text { Subsection } 66.5 \text { empowers the SEC to provide assistance for any foreign enforcement authority } \\
\text { authorized to provide reciprocal assistance. The assistance includes the disclosure of "any" } \\
\text { information filed with or transmitted to the SEC if the requesting authority is conducting a } \\
\text { securities- or commodity-related investigation to determine violation of securities or } \\
\text { commodity laws. This clearly includes non-public, commercially sensitive or confidential } \\
\text { information regarding a licensee, a listed company and beneficial shareholders. Assistance that } \\
\text { can be provided includes requesting cooperation of holders of information and summoning } \\
\text { witnesses to testify in any proceeding of the SEC and/or to produce affidavits, as provided by } \\
\text { Section 5.(h) and (l) of the SRC. The "any" information is understood to include that regarding } \\
\text { regulatory processes of the SEC. The types of information may also include banking and } \\
\text { brokerage records. The SEC provides such information regardless of whether an investigated } \\
\text { matter constitutes a violation of law of the Philippines. However, the SEC's access to banking } \\
\text { records is limited by the Bank Secrecy Law. The Bank Secrecy Law requires a court order in } \\
\text { order for the SEC to obtain information regarding bank accounts. }\end{array}$ \\
\hline Asse & Implemented \\
\hline Comn & city clauses. \\
\hline Principle 14. & $\begin{array}{l}\text { There should be full, accurate and timely disclosure of financial results and other information } \\
\text { that is material to investors' decisions. }\end{array}$ \\
\hline Description & $\begin{array}{l}\text { Disclosure requirements are another area which was purposely strengthened under the SRC and } \\
\text { have been The disclosure requirements in the SRC and the IRR are modeled after those in the } \\
\text { United States. Section } 8 \text { of the SRC requires registration of securities and disclosure of } \\
\text { information about the securities prior to sale to the public. Section } 9 \text { defines exempted securities } \\
\text { which include those issued or guaranteed by the government. However, bank shares are not } \\
\text { exempted. Section } 10 \text { provides that the registration requirement is exempted for issuance to the } \\
\text { existing shareholders without payments, conversion of existing securities, private placement to } \\
\text { fewer than } 20 \text { persons or to any number of professional institutional investors as defined by } \\
\text { Section 10.(1). SRC Rule } 8 \text { provides further details of the registration requirement. SRC Rule }\end{array}$ \\
\hline
\end{tabular}


8.1-1 provides rules for delivery of Prospectus for the public issuance of securities which are required to be registered. It includes filing of Preliminary Prospectus with the registration. SRC Rule 8.3-1 provides restrictions and requirements for advertisement, road shows, etc. prior to effectiveness of the registration.

Section 12 of the SRC and Annex C of SRC Rule 12 provides procedure for the registration and detailed disclosure requirements including: i) description of the business including information on company formation and by-laws, ii) description of the securities, iii) financial information, iv) management and certain securities holders including directors and other officers and their compensations, shareholdings and related transactions; v) registration statement and prospectus provisions, vi) exhibits to be included. Regarding the requirement of description of securities, the issuance of options requires disclosure of information specific to the instrument (e.g., the terms of the plan, names or beneficiaries or eligible participants). The issuance of preferred shares requires, among other things, description of the sinking fund and the shares' rights and preferences. Debt issuers are required to state its satisfaction of a requirement to have net worth exceeding P25 million and have been in business at least three years. They are also required to state whether unsecured bonds are to be issued. Investment companies and Oil and Mining companies are required of special information disclosure.

Section 17 provides requirements of periodic reports and current reports on material events by the issuers of securities which are required to be and have been registered except those which have less than 100 shareholders or assets less than P50 million. However, any issuers whose securities are listed on the Exchange must meet the reporting requirements. In fact, companies listed on an Exchange must file with the Exchange all reports filed with the SEC (Section 17.3 of the SRC). PSE may require, based on its listing rules and full disclosure policy, further information to be disclosed. Annual report to be filed with the SEC must contain a balance sheet, profit and loss statement and statement of cash flow and be audited by an independent certified public accountant. Such issuers much also file with the SEC interim fiscal (quarterly) reports and current reports on material events. The issuers are also required to distribute information or a proxy statement which contain information which will help the shareholders make voting decisions (SRC Rule 17.1(b)). The SRC Rules provide in its Annexes various SEC forms (e.g., SEC Form 17-A for Annual Report, SEC Form 17-Q for Quarterly Report, SEC Form 17-C for Current Report, etc., etc.) to be filled and filed with the SEC. Section 18 provides a requirement of reporting of holding or acquisition of 5 percent or more equity securities. As provided by Section 66 of the SRC and SRC Rule 66.3, however, the issuer can request the SEC's confidential treatment of trade secrets or other sensitive strategic business information (such as merger negotiation, etc.) to be withheld from disclosure although such request is subject to review by the SEC.

The SEC may reject or revoke registration statement and refuse registration after due notice and hearing if the issuer, among other things, made false or misleading representation of material facts (Section 13). It can review, approve and order amendments to registration statement (Section 14). The SEC can suspend the registration if the information filed is or become materially misleading, incorrect inadequate or incomplete or fraudulent (Section 15). It then requests relevant further information from the issuer and considers whether the registration should be revoked. Section 13.4 also provides that the SEC can issue an order to the issuer and/or broker dealers which are participating in the issue to suspend an offer pending any investigation. The SEC is required to state the grounds for such actions in the order. Such an order, however, is kept confidential (i.e., not to be published) while binding on the issuer and the broker dealers. Until the order is lifted or set aside by the SEC, any sale thereof shall be void. Hence, the grounds for rejection, revocation or suspension may be civil, administrative or criminal.

An investor is provided under Section 56 of the SRC with private rights of actions to bring a civil law suit against, among others, the underwriter, the auditor as well as the issuer and/or its directors in case the investor believes to have suffered from damages / losses due to inadequate and/or misleading disclosure (in prospectus, etc.). Section 57 holds civilly liable the issuer, the underwriter and the auditor, etc. to investors who suffered damages for such reasons. The PSE 


\begin{tabular}{|c|c|}
\hline & $\begin{array}{l}\text { Rules and Regulations (V. Rules on Listing) hold the lead underwriter which is a member of the } \\
\text { PSE responsible for conducting due diligence to ensure the issuer's compliance with the } \\
\text { contents and procedures of disclosure. More generally, duties of directors, officers to the } \\
\text { company and its shareholders are defined in Corporation Code (Title III of the Code). }\end{array}$ \\
\hline Assessment & Implemented \\
\hline Comments & $\begin{array}{l}\text { The legal and regulatory requirements are sound. The SEC needs to improve its enforcement of } \\
\text { the new requirements and standards and educate the regulated persons on those for more } \\
\text { effective implementation of the full disclosure regime. Staff skill also needs to be improved } \\
\text { particularly with regard to detection of financial fraud. While the SRC and its IRR include } \\
\text { disclosure requirements for exchange-listed companies, the PSE ensures that such requirements } \\
\text { are met by its listed companies. Thus, the SEC has authority to delay listing at the PSE when a } \\
\text { listed-issuer is not in compliance with the SRC or the IRR. In reality, however, the PSE as an } \\
\text { SRO directly exercise such control. } \\
\text { The SEC plans to develop brochures and guidelines on areas of disclosure which raise } \\
\text { compliance issues (e.g., beneficial ownership, timing of disclosure of material corporate } \\
\text { events). The SEC recently helped conduct the successful first seminar on full disclosure. It was } \\
\text { well attended and considered highly successful by the participants (issuers and underwriters) in } \\
\text { enhancing their understanding of new disclosure requirements and standards under the SRC and } \\
\text { the IRR. The SEC intends to conduct more such seminars to alert the issuers and underwriters } \\
\text { on their obligations. SRC Rules can also provide some clarification regarding circumstances } \\
\text { under which either the issuer or the underwriter or the auditor is not liable for damages incurred } \\
\text { by investors while the other(s) is/are. For example, if the issuer did not honestly disclose } \\
\text { material information which the underwriter could not reasonably find out about, only the issuer } \\
\text { may be held liable. Likewise, if some misleading information was included due to a fault by the } \\
\text { underwriter but not the issuer, only the underwriter may be held liable. }\end{array}$ \\
\hline Principle 15. & Holders of securities in a company should be treated in a fair and equitable manner. \\
\hline Description & 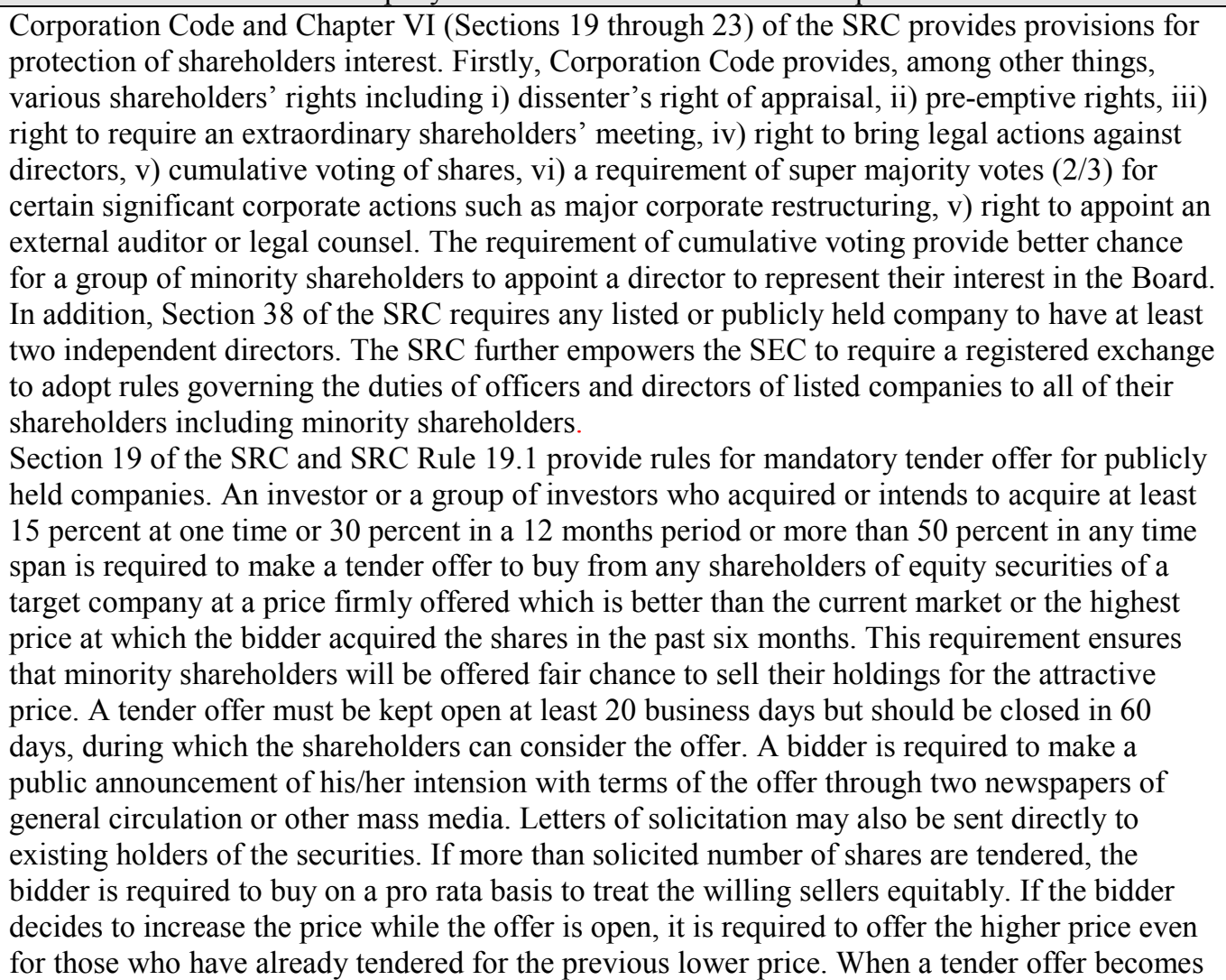 \\
\hline
\end{tabular}




\begin{tabular}{|c|c|}
\hline & 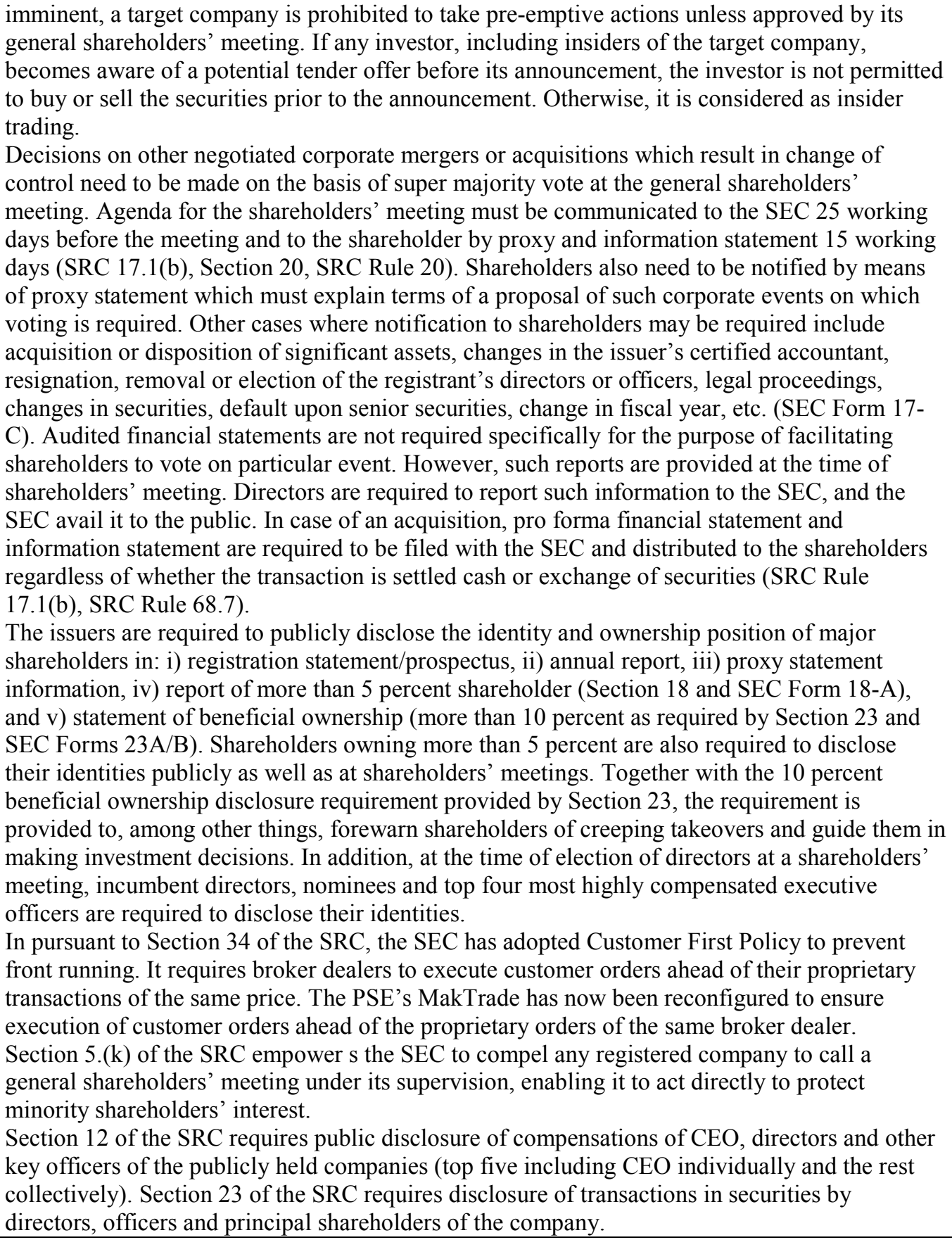 \\
\hline Assessment & Implemented \\
\hline Comments & $\begin{array}{l}\text { The SEC's power to compel any registered company t call a general shareholders' meeting } \\
\text { under its supervision is an extraordinarily strong power of the SEC of the Philippine not } \\
\text { commonly found in securities regulators of other jurisdictions. It gives a great responsibility as } \\
\text { well as power to protect interest of minority shareholders. The SEC actually can sue a } \\
\text { registered company, the directors, underwriter, auditor, etc. on behalf of its shareholders upon } \\
\text { receipt of an appropriate complaint(s). Based on Section } 63 \text { of the SRC, court can also award } \\
\text { attorney's fee when a small shareholder(s) wishes to sue the issuer, etc., which provides effect } \\
\text { similar to class action. Overall, the SRC and its Rules provide adequate protection to } \\
\text { shareholders. However, enforcement may be enhanced by the SEC and particularly the PSE. }\end{array}$ \\
\hline
\end{tabular}




\begin{tabular}{|c|c|}
\hline & $\begin{array}{l}\text { Recently, the SEC has approved Code of Corporate Governance which is mandatory for all } \\
\text { corporations whose securities are registered or listed. } \\
\text { In addition to the need to improve the enforcement effort, one of the main impediments to } \\
\text { improving minority shareholders rights is the limited public float of securities in the } \\
\text { Philippines. A majority of companies listed on the PSE are controlled by a small number of } \\
\text { shareholders, most of who comprise family members. Until the market has developed to a point } \\
\text { where there are tangible financial benefits to listing and to making publicly available a larger } \\
\text { percentage of outstanding securities, it will be difficult to change the share ownership structure. } \\
\text { Thus, minority shareholders have little chance of influencing decision making at these } \\
\text { companies. }\end{array}$ \\
\hline Principle 16. & Accounting and auditing standards should be of a high and internationally acceptable quality. \\
\hline Description & 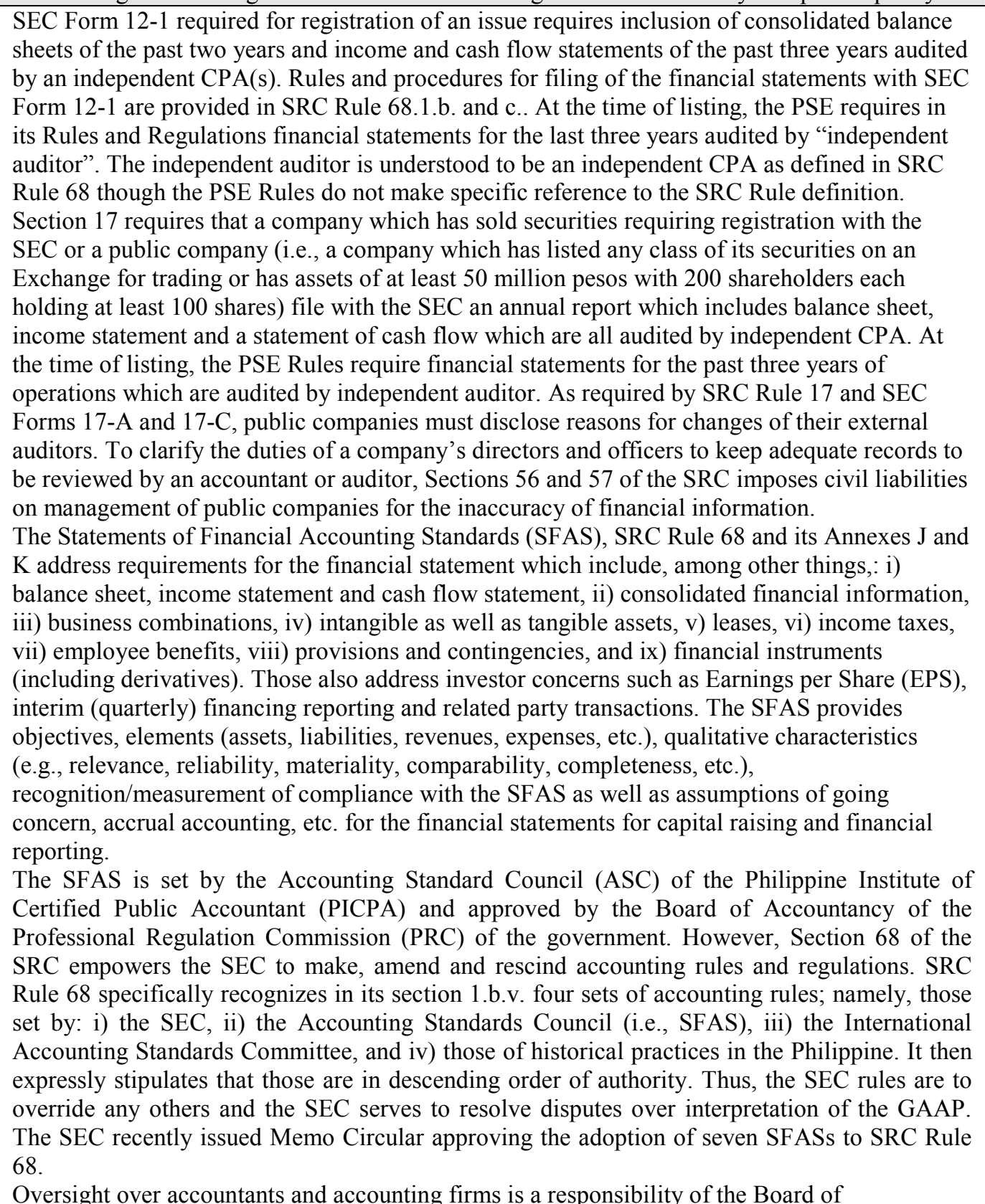 \\
\hline
\end{tabular}




\begin{tabular}{|c|c|}
\hline & $\begin{array}{l}\text { Accountancy of the PRC, and the SEC does not have authority to directly regulate or supervise } \\
\text { accountants. However, the SEC has authority to review financial statements filed by public } \\
\text { companies and challenge application of accounting standards. It can directly impose } \\
\text { administrative sanctions on accountants in case of misrepresentation of material facts or failing } \\
\text { to conduct proper due diligence of an issuer of securities (under Section } 54 \text { of the SRC). The } \\
\text { SEC can also refer such cases to the Board of Accountancy which can further penalize the } \\
\text { accountant with revocation of its license. In addition, affiliation of CPAs with PICPA in which } \\
\text { the SEC is represented also help ensure proper application of the SFAS. The ASC publishes } \\
\text { comments on pronouncements regarding application of accounting standards. Further more, the } \\
\text { recently promulgated Code of Corporate Governance, which is to be enforced by the SEC, } \\
\text { specifies responsibilities of external and internal auditors and stipulates specific manners in } \\
\text { which independence of external auditors is secured. The SEC is working with the Board of } \\
\text { Accountancy and the PICPA to improve compliance and discipline of auditors and accountants } \\
\text { who fail to adhere to these standards. } \\
\text { The SFAS includes the Code of Ethics for CPAs which addresses: a requirement and criteria of } \\
\text { independence of auditors, authorization of auditors (i.e., CPA), use of due professional care, } \\
\text { proper planning and supervision of the audit, understanding of the internal control system of the } \\
\text { audited, and a need to obtain evidence that financial statements are free of material } \\
\text { misstatements. The SFAS also requires that auditor's report to disclose in footnotes: i) } \\
\text { exceptions to application of accounting standards, ii) material uncertainties and iii) going } \\
\text { concern issues. A requirement of continuous auditing education has been eliminated this year. }\end{array}$ \\
\hline Assessment & Implemented \\
\hline Comments & $\begin{array}{l}\text { The SEC is in the process to implement the International Accounting Standards (IASs) and has } \\
\text { a specific plan to do so by year } 2005 \text {. The SEC is currently revising SRC Rule } 68 \text { to } \\
\text { incorporates seven revised SFASs which adopted six IASs. Improvements are also needed with } \\
\text { respect to enforcement of compliance with the standards and quality of audits and the need for } \\
\text { better coordination between the SEC and the Board of Accountancy in detecting and } \\
\text { disciplining accountants for violation of accounting and auditing standards. } \\
\text { The requirement of audited financial statements at the time of registration and issuance of } \\
\text { securities is hard to find in the SRC and the IRR. Prospectus is required to include only } \\
\text { abbreviated financial statements summarized from full hedged, audited financial statements. } \\
\text { SRC Rule } 12 \text { requires, at the time of issue, only "non-financial" statement portions of annual, } \\
\text { quarterly and current reports. SRC Rule } 12-2 \text { is not explicit about "requirement" of financial } \\
\text { statements while Part V of Annex C for SRC Rule } 12 \text { only "implicates" in its (B)(5) that Item } \\
12 \text { of SEC Form } 12-1 \text { requires detailed financial statements. The explicit requirement is } \\
\text { provided in SRC Rule } 68.2 \text {.b. and c.. However, the rule is supposed to be a place to substantiate } \\
\text { the generic power of the SEC to provide accounting rules as provided by Section } 68 \text { of the } \\
\text { SRC. The SRC and the IRR could be amended to make this important requirement clearer in } \\
\text { Section } 12 \text { of the SRC and corresponding Rules. }\end{array}$ \\
\hline Principle 17. & $\begin{array}{l}\text { The regulatory system should set standards for the eligibility and the regulation of those who } \\
\text { wish to market or operate a collective investment scheme. }\end{array}$ \\
\hline Description & $\begin{array}{l}\text { The Investment Company Act (ICA) adopted in } 1960 \text { sets out eligibility standards for } \\
\text { marketing and operation of a collective investment scheme (CIS). The Act addresses the } \\
\text { operator's: fitness and properness, honesty and integrity, human and technical competence, } \\
\text { adequacy of financial capacity, capacity to discharge powers and duties, and adequacy of } \\
\text { internal management and control. Employees of the operator or the marketer are required to } \\
\text { pass a qualifying examination given by the CMD in addition to satisfying the similar fitness and } \\
\text { properness standards before they operate or market CISs. The operator is required to publicly } \\
\text { disclose qualifications and eligibility of its employees and itself. Operation of a CIS by an } \\
\text { authorized operator is subject to fine and suspension of the operation. The operator is required } \\
\text { to report to the SEC periodically and currently on material changes in its management or } \\
\text { organization. } \\
\text { Provisions of the ICA regarding conduct of the operator are designed to address conflicts of }\end{array}$ \\
\hline
\end{tabular}




\begin{tabular}{|c|c|}
\hline & 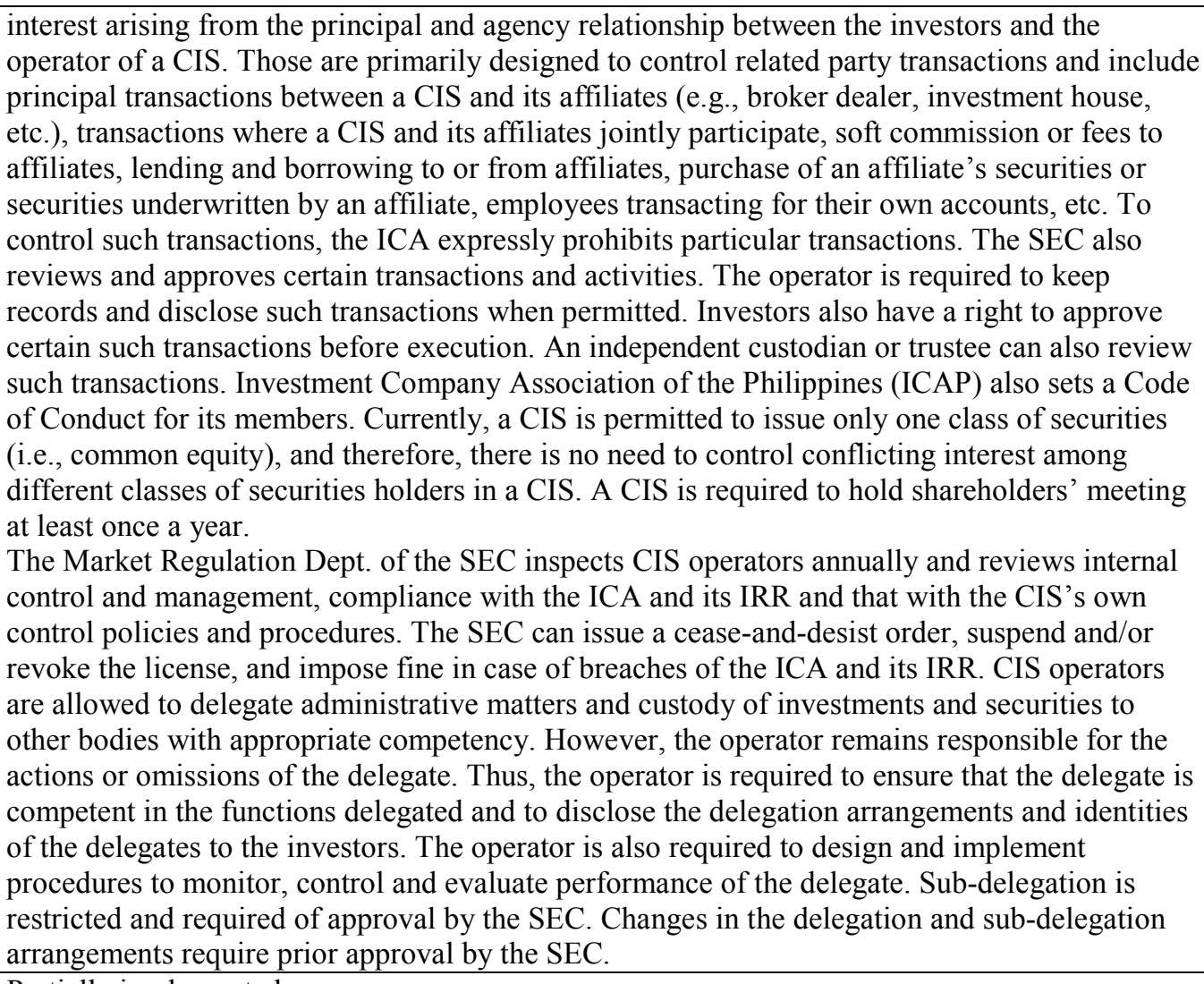 \\
\hline Assessment & Partially implemented \\
\hline Comments & $\begin{array}{l}\text { The existing ICA provides most of the necessary elements of investment company regulation. } \\
\text { However, it requires clarification and rationalization in its variety of parts in order to be brought } \\
\text { up to sound international practices. It also does not allow foreign investors in investment } \\
\text { companies to elect their representative(s) for the Board of Directors of the investment } \\
\text { companies. While this is not a criterion of this assessment, it discourages foreign participation } \\
\text { in this potentially important business for long-term savings mobilization. The proposed law } \\
\text { called the Revised Investment Company Act (RICA), which has been drafted and is being } \\
\text { considered by the Congress, is to address this issue. It is also to provide clarification and more } \\
\text { detailed provisions and rationalize the provisions of the existing ICA. For example, the new } \\
\text { RICA is to group all provisions related to affiliated party transactions (i.e., a core of CIS } \\
\text { regulation to control conflicts of interest and agency problems) under its Chapter IV and } \\
\text { strengthen those. It is also to bring Investment Advisor within the framework of related parties } \\
\text { regulation while the ICA does not capture investment advisors despite the fact that investment } \\
\text { advisors contract for management of assets of investment companies. Passage of RICA, when } \\
\text { materialized, will bring to the SEC authority to regulate investment advisor. } \\
\text { The SEC hopes that the new RICA will be passed by the Congress soon. The SEC received } \\
\text { assistance regarding regulation of investment companies from the Canadian International } \\
\text { Development Agency (CIDA) in mid-June of last year. This assistance included the help of a } \\
\text { consultant who reviewed the existing ICA and its IRR and helped the SEC address gaps } \\
\text { through the new legislation and/or rulemaking. Full implementation of this Principle is } \\
\text { dependent upon passage of the RICA and issuance of corresponding IRR by the SEC. }\end{array}$ \\
\hline Principle 18. & $\begin{array}{l}\text { The regulatory system should provide for rules governing the legal form and structure of } \\
\text { collective investment schemes and the segregation and protection of client assets. }\end{array}$ \\
\hline Description & $\begin{array}{l}\text { The existing ICA provides in its Section } 4 \text { definition of investment company and in Section } 5 \\
\text { classification of investment companies. Under the ICA, investment company is a corporation }\end{array}$ \\
\hline
\end{tabular}




\begin{tabular}{|c|c|}
\hline & 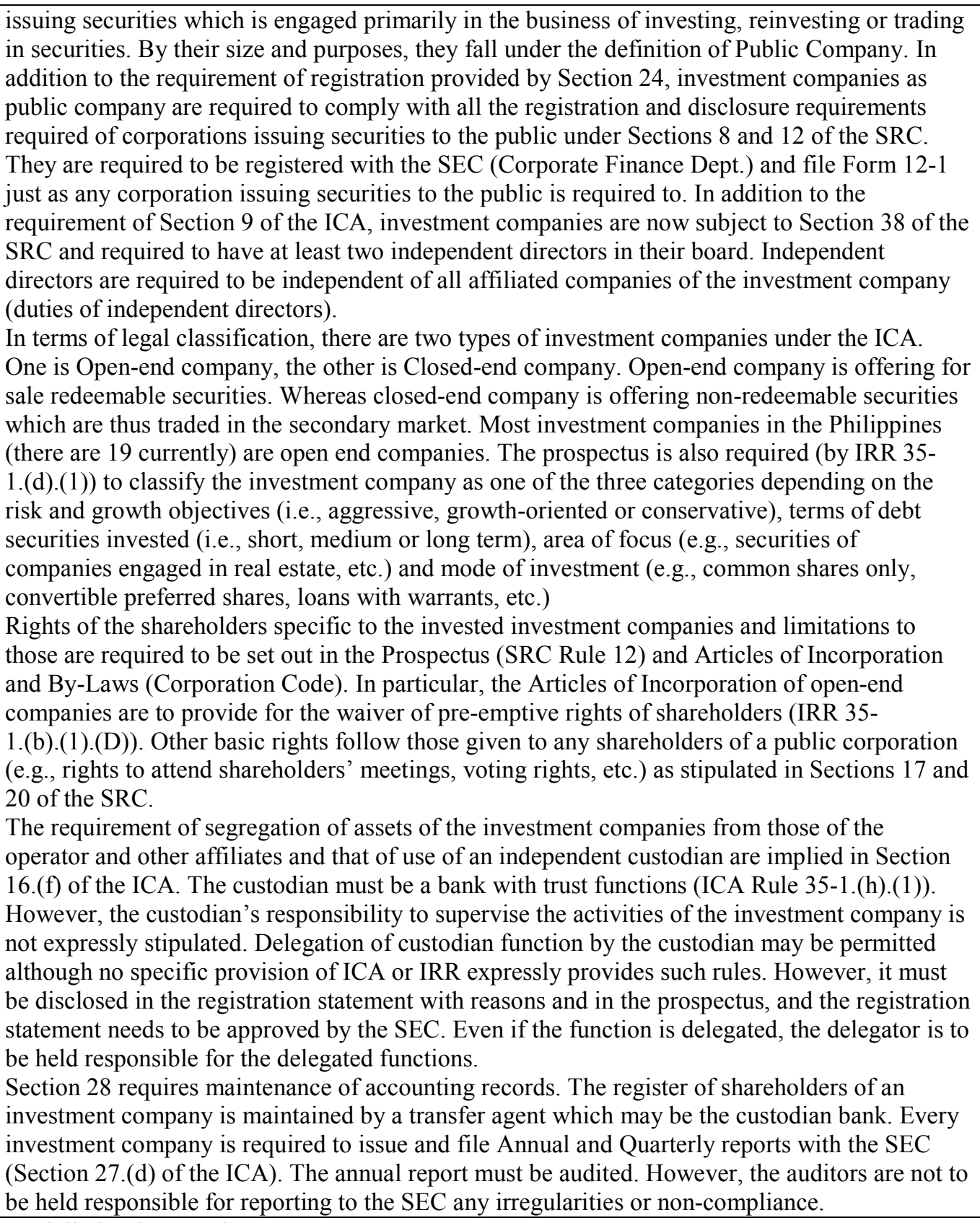 \\
\hline Assessment & Partially implemented \\
\hline Comments & $\begin{array}{l}\text { The ICA needs some tightening and fine tuning. For example, the requirement of segregation is } \\
\text { not entirely clear. Section 16.(f) reads as the SEC is to issue IRR or Order to provide a specific } \\
\text { segregation requirement. However, no such IRR or Order is found. Likewise, the requirement to } \\
\text { transfer agent to maintain a register of shareholders is not entirely clear. Rules for delegation of } \\
\text { functions are also not provided. RICA will address, among other things, segregation of client } \\
\text { assets, and its passage by the Congress is awaited. The SEC is encouraged to provide further } \\
\text { detailed provisions after the issuance of RICA. However, many detailed rules needed may be } \\
\text { provided by the SEC even based on the existing ICA. }\end{array}$ \\
\hline Principle 19. & $\begin{array}{l}\text { Regulation should require disclosure, as set forth under the principles for issuers, which is } \\
\text { necessary to evaluate the suitability of a collective investment scheme for a particular investor }\end{array}$ \\
\hline
\end{tabular}


and the value of the investor's interest in the scheme.

\begin{tabular}{|c|c|}
\hline Description & 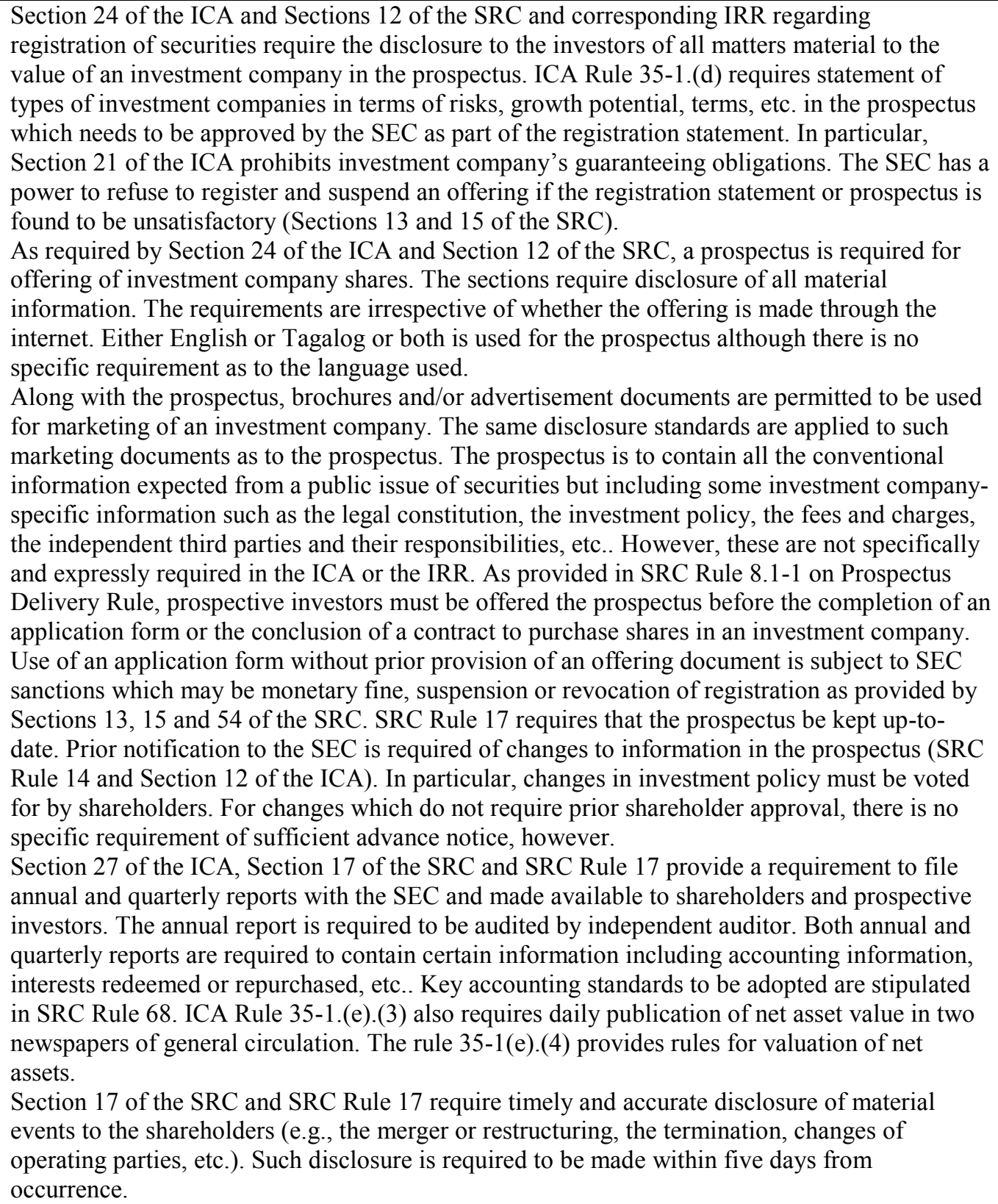 \\
\hline Assessment & Partially implemented \\
\hline Comments & $\begin{array}{l}\text { Improvements are needed for, among other things, requirements for disclosure of sufficient } \\
\text { information to evaluate investments and powers to enforce disclosure requirements, which are } \\
\text { expected to be addressed by the RICA. While items for disclosure are well specified in SRC } \\
\text { Rule 17, the ICA and the IRR do not expressly provide investment company-specific } \\
\text { information requirements. The proposed RICA will incorporate the concept of full disclosure to } \\
\text { complement the full disclosure requirements of the SRC. The SEC received TA in mid-June last } \\
\text { year to upgrade the law. }\end{array}$ \\
\hline mсіріе 20. & $\begin{array}{l}\text { Regulation should ensure that there is a proper and disclosed basis for asset valuation and the } \\
\text { pricing and the redemption of units in a collective investment scheme. }\end{array}$ \\
\hline Description & des basic rules for the net asset valuation. The rule $35-1 .(\mathrm{e}) .(3)$ \\
\hline
\end{tabular}




\begin{tabular}{|c|c|}
\hline & $\begin{array}{l}\text { requires daily publication of the net asset value in two newspapers of general circulation. } \\
\text { Prospectus must also specify redemption policy and fees. The CIS operator is responsible for } \\
\text { valuation of the assets and its publication. Independent external auditing is required only for the } \\
\text { annual report but not for the daily valuation. } \\
\text { ICA Rule } 35 \text {.(e).(5) requires that payments for redemption be made within seven business days. } \\
\text { Fees and charges are disclosed in the prospectus although there is no specific and explicit } \\
\text { regulatory requirement as such. } \\
\text { There is no specific rules or mechanisms of pricing control (e.g., regular reconciliation, periodic } \\
\text { audit) to identify and rectify error, omissions or misplacement of assets. Nor are there any rules } \\
\text { for addressing pricing errors such as: materiality benchmarks, benchmark triggering } \\
\text { compensation, circumstances calling for enforcement actions, dispute resolution mechanism. } \\
\text { ICA Rule 35-1.(e).(6) provides that the SEC may suspend or defer the redemption of open-end } \\
\text { companies whenever necessary or appropriate in the public interest or for the protection of } \\
\text { investors. This enables the SEC to intervene a possible run on an open-end fund and prevent a } \\
\text { market panic. Investment company can also apply for the suspension or deferral by the SEC } \\
\text { although there is no specific provision as such in the ICA or its IRR. There is no limit imposed } \\
\text { by regulation on the amount of redemption allowed to be deferred on a daily or periodic basis. } \\
\text { However, the SEC has a power to demand, delay or stop the deferral or suspension of } \\
\text { redemption rights. }\end{array}$ \\
\hline Assessment & Partially implemented \\
\hline Comments & $\begin{array}{l}\text { More detailed standards for asset valuation need to be developed. The existing Investment } \\
\text { Company Act addresses the issue. However, the accounting practices need to be standardized } \\
\text { (e.g., amortization). Improvements are needed for, among other things, requirements for } \\
\text { valuation and disclosure of the value of interests in a CIS, capacity to enforce disclosure } \\
\text { requirement, and requirements for pricing and redemption of units. The custodian bank may be } \\
\text { required to control pricing and valuation by providing its net asset valuation to check the } \\
\text { accuracy of the operator's valuation. Some rules may also be given to specify circumstances } \\
\text { under which closed end funds may repurchase its shares. The SEC is waiting for passage of the } \\
\text { RICA. In addition to the TA received in June } 2000 \text {. the SEC is also working with the } \\
\text { investment company industry to develop standards for net asset value calculation. While not a } \\
\text { criterion of IOSCO Principles assessment, exchange trading of open-end investment companies } \\
\text { may be considered. }\end{array}$ \\
\hline Pri & Regulation should provide for minimum entry standards for market intermediaries. \\
\hline Des & $\begin{array}{l}\text { The legal infrastructure for regulating market intermediaries has been enhanced in the SRC } \\
\text { which, among other things, raises capital requirements (initial and ongoing), provides a } \\
\text { disciplinary bar to registration, provides for indefinite registration, and clarifies that all } \\
\text { regulated intermediaries must register under the new law. } \\
\text { Investment Houses (Presidential Decree 129), Broker Dealers (SRC), Financing Companies } \\
\text { (Financing Company Act of 1998) are primary NBFIs authorized and regulated by the SEC. } \\
\text { Among them, the Investment Houses and Broker Dealers are the primary securities market } \\
\text { intermediaries while the Financing Companies are essentially credit institutions without deposit } \\
\text { taking. Among them, Investment Houses and Financing Companies are eligible for quasi- } \\
\text { banking and trust licenses which are to be given by the BSP. The quasi-banking function is } \\
\text { defined as borrowing from the public (i.e., more than } 19 \text { creditors). If they are licensed by the } \\
\text { BSP for quasi-banking functions, they are to be supervised also by the BSP. Such borrowing } \\
\text { from the public is considered as a "deposit substitute," and the borrowing intermediary is to be } \\
\text { made subject to, among other things, the reserve requirement. The NBFIs can also be owned by } \\
\text { or affiliated to Universal Banks or Commercial Banks, which can also be a ground on which the } \\
\text { BSP exercises supervisory authority over them. Universal Banks themselves have the power of } \\
\text { the Investment Houses (Section } 23 \text { of the General Banking Law) in themselves, and, therefore, } \\
\text { can conduct all the securities business under its own roof, in which case they have to be } \\
\text { registered as such with the SEC. So far, however, most Universal Banks have chosen to do the } \\
\text { business through subsidiaries Investment Houses or Broker Dealers. }\end{array}$ \\
\hline
\end{tabular}




\begin{tabular}{|c|c|}
\hline & 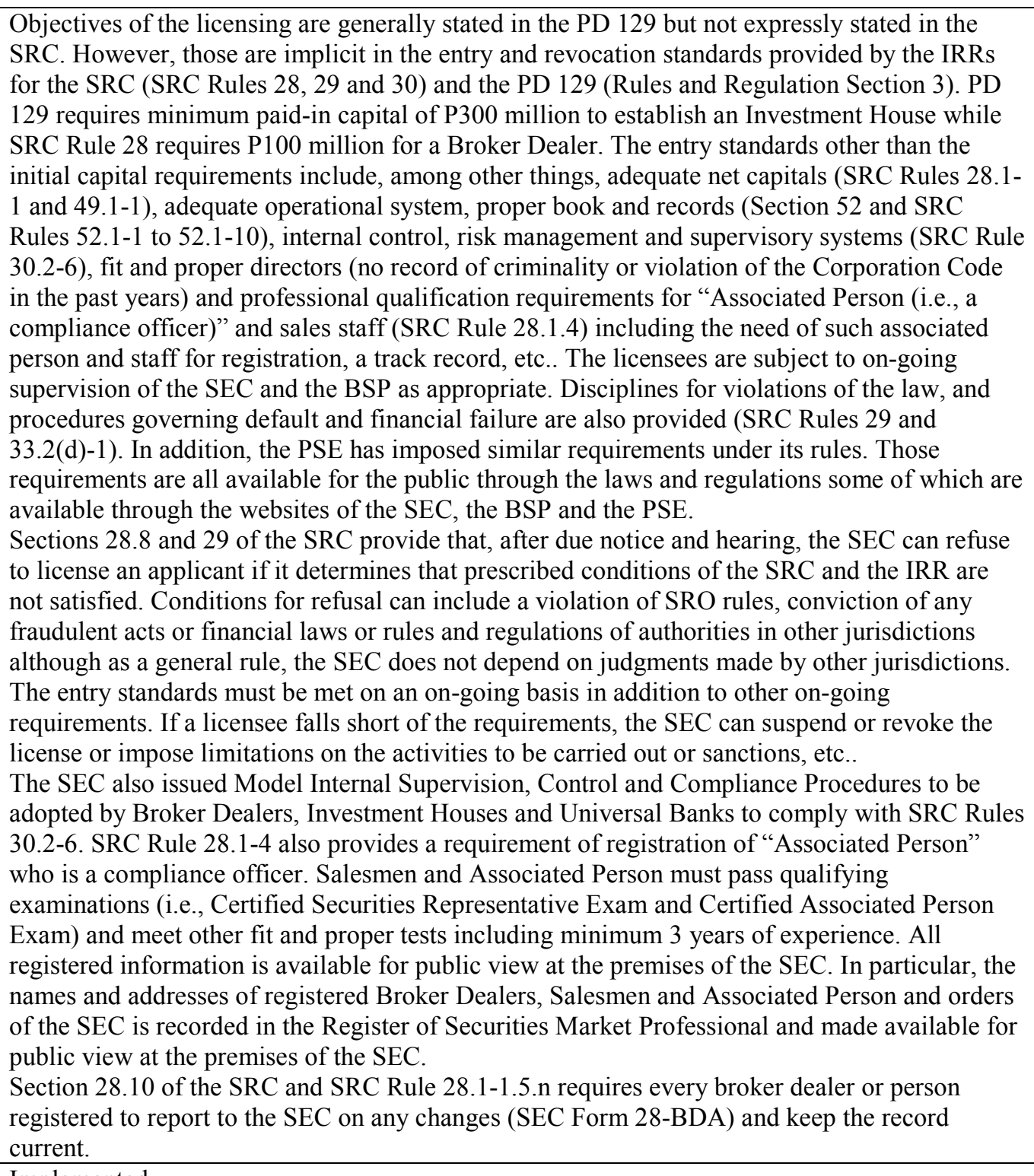 \\
\hline Assessment & Implemented \\
\hline Comments & $\begin{array}{l}\text { The scope of the SEC' regulatory responsibility with respect to the variety of financial } \\
\text { institutions is somewhat overly broad relative to its capacity and resources. Currently, the SEC } \\
\text { is also to regulate Pre-Need Plans while the SEC's regulatory authority over Lending Investors } \\
\text { and Money Changers is somewhat unclear. For example, most, if not all, Lending Investors are } \\
\text { single proprietorships and, therefore, not registered at the SEC as corporation or partnership. } \\
\text { Instead, they are registered at the Department of Trade and Industry (DTI). In addition, there is } \\
\text { no law to govern the business of Lending Investors. SEC's power to regulate Pre-Needs is } \\
\text { given by Section } 16 \text { of the SRC, and the SEC has issued the New Rules on the Registration and } \\
\text { Sale of Pre-Need Plans in addition to SRC Rule } 16.1-1 \text { Transition Rule for Pre-Need Plans. } \\
\text { However, the business of Pre-Need Plans is more similar by nature to that of insurance } \\
\text { companies. The authority to regulate Pre-Needs is now expected to be transferred to the } \\
\text { Insurance Commission. Even the Financing Companies are essentially credit institutions and } \\
\text { not important intermediaries of the securities market while the business of Money Changers and } \\
\text { Money Transmitters may be considered as "banking functions." Further rationalizations of the }\end{array}$ \\
\hline
\end{tabular}




\begin{tabular}{|c|c|}
\hline & $\begin{array}{l}\text { scope of the SEC's regulatory responsibility seems to be necessary in order to permit the SEC } \\
\text { to focus on its core responsibility as the securities market regulatory and supervisory authority } \\
\text { unless the Philippines should decide to create an integrated financial sector supervisor for the } \\
\text { increasingly conglomerating/universalizing financial sector as a whole. } \\
\text { The SEC is encouraged to make efforts to ensure the public's easy access to the information } \\
\text { regarding eligibility and qualification of intermediaries, their management and staff available } \\
\text { for public view. The SEC is encouraged to avail the Register of Securities Market professionals } \\
\text { through the internet to enhance accessibility to the information by the public (e.g., CDR or } \\
\text { other similar systems of the National Futures Association of the US and others). While a } \\
\text { licensed Broker Dealer is "required" to be a member of an SRO, it appears that SRC Rule } 28.1- \\
1.5 \text { is referring generally to industry associations as SRO since, otherwise, all licensed Broker } \\
\text { Dealers "must" be members of the PSE, which is not the case. The SEC may wish to clarify this } \\
\text { point in the rule. }\end{array}$ \\
\hline Principle 22. & $\begin{array}{l}\text { There should be initial and ongoing capital and other prudential requirements for market } \\
\text { intermediaries that reflect the risks that the intermediaries undertake. }\end{array}$ \\
\hline Description & 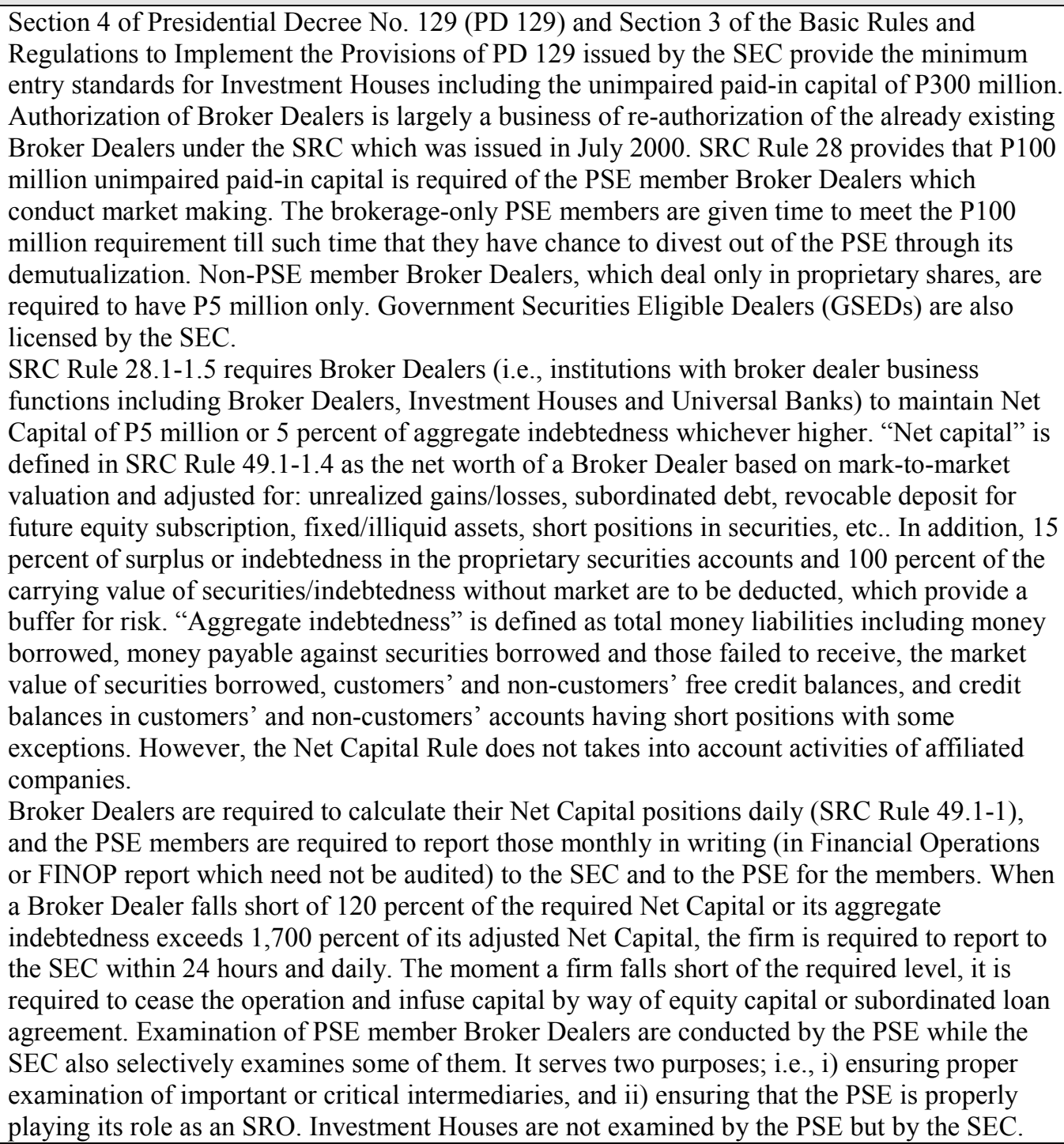 \\
\hline Assessment & Implemented \\
\hline Comments & e sheet items of both short-term and long- \\
\hline
\end{tabular}




\begin{tabular}{|c|c|}
\hline & $\begin{array}{l}\text { term nature reflecting concerns for both solvency and liquidity. Mark-to-market valuation is } \\
\text { applied for the calculation while liquidity of certain assets and liabilities and off-balance sheet } \\
\text { items are taken into account. Hair cuts are applied to illiquid assets to account for the risk } \\
\text { depending on marketability of assets in question. Those include shares and securities of } \\
\text { affiliates held for strategic purposes. } \\
\text { The SEC plans to improve the monitoring of the net capital positions by computerization to } \\
\text { achieve daily reporting/monitoring. It is also committed to taking enforcement actions. It is } \\
\text { reviewing rules and procedures of the Securities Investor Protection Fund (SIPF) to ensure that } \\
\text { in the event of insolvency of an brokerage firm, the SIPF is adequate and that customers are } \\
\text { timely compensated. In addition, the SEC mandated the Securities Clearing Corporation of the } \\
\text { Philippines (SCCP) to execute a "credit ring agreement (see Principle 24)" with its participants. } \\
\text { However, the Rule is formulated for broker dealer business functions only. It is recommendable } \\
\text { that the Net Capital Rule take into account not only the securities of affiliated companies but } \\
\text { also their activities. }\end{array}$ \\
\hline Principle 23. & $\begin{array}{l}\text { Market intermediaries should be required to comply with standards for internal organization } \\
\text { and operational conduct that aim to protect the interests of clients, ensure proper management } \\
\text { of risk, and under which management of the intermediary accepts primary responsibility for } \\
\text { these matters. }\end{array}$ \\
\hline Description & 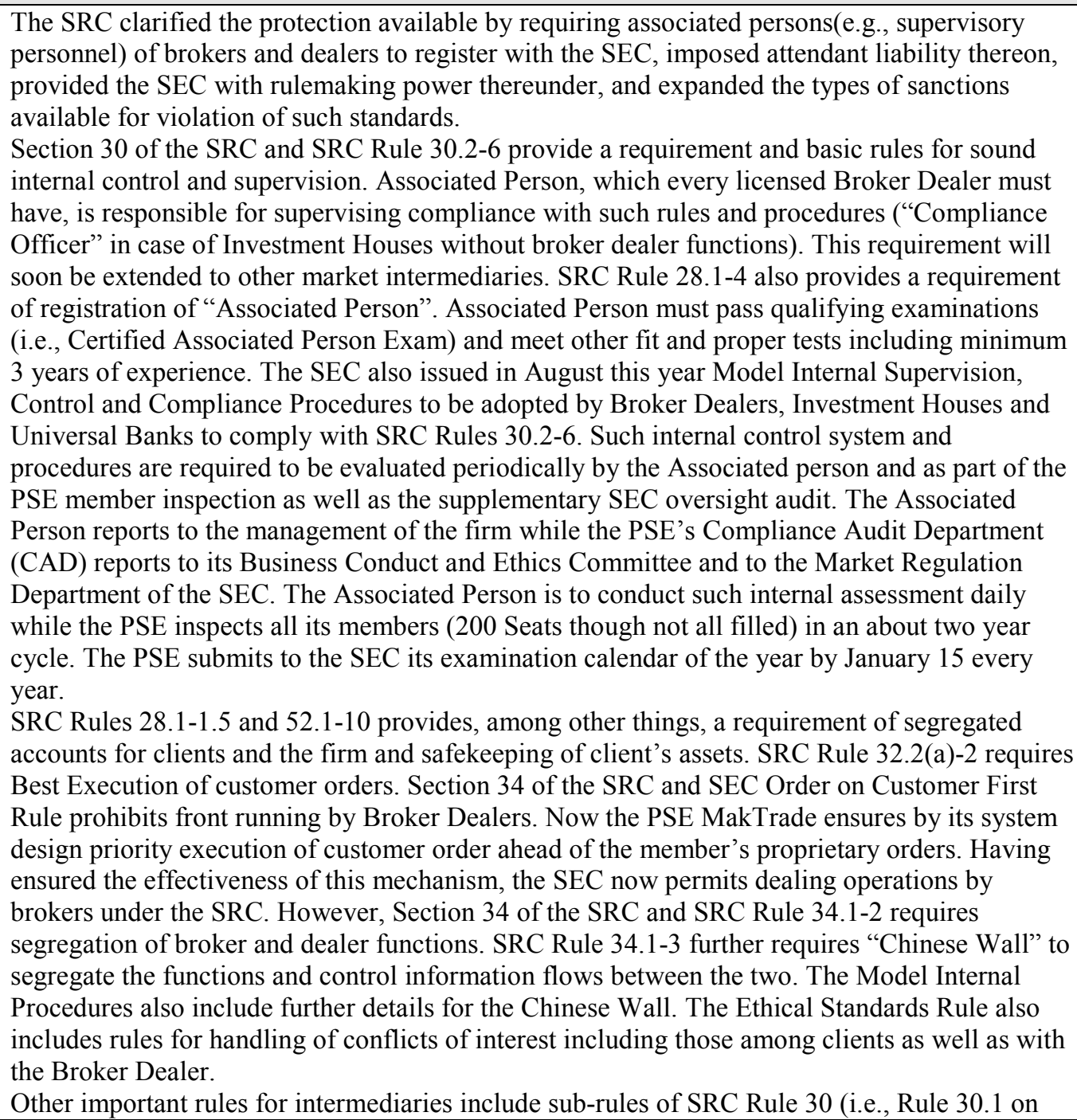 \\
\hline
\end{tabular}




\begin{tabular}{|c|c|}
\hline & $\begin{array}{l}\text { Monitoring of Affiliated Transactions by Broker Dealer, Rule 30.2-1 on Ethical Standards Rule, } \\
\text { Rule } 30.2-2 \text { on Confirmation of Customer Orders, Rule } 30.2-3 \text { on Client Agreement, Rule 30.2- } \\
4 \text { on Suitability Rule, i.e., (together with SRC Rule 30.2-1.2.d, Know-Your-Client rule), and } \\
\text { Rule } 30.2-5 \text { on Commissions and Charges for Services Performed by Broker Dealer). SRC Rule } \\
24 \text { also provide in its sub-rules } 24.1 \text { (b)-1 on Manipulative Practices, } 24.1(\mathrm{~d})-1 \text { on } \\
\text { Advertisements and Communications with the Public, and } 24.2-3 \text { on Prohibition of Guarantees } \\
\text { against Loss. SRC Rule } 52 \text { provides in } 52.1-8 \text { on Customer Account Statements and } 52.1-9 \text { on } \\
\text { Customer Complaint Rule. The rule } 30.2-3 \text { requires that a Client Agreement, which specifies in } \\
\text { details terms of the contract including identities of the client and the Broker Dealer, the nature } \\
\text { of the services, fees, etc. as well as risk disclosure, be signed before transacting or providing } \\
\text { any services. In case of subscription of a public offering, the prospectus must also be provided } \\
\text { for the client. The rule } 30.2-2 \text { provides executed transactions be reported immediately to the } \\
\text { clients and be followed by a Confirmation Advice the following day. The rule } 52.1-8 \text { requires } \\
\text { quarterly statements of accounts be sent to the clients. As part of the Ethical Standards Rule, } \\
\text { SRC Rule } 30.2-1 . d \text { together with SRC Rule } 30.2-4 \text { provides an obligation of an intermediary to } \\
\text { obtain information from its client including the financial circumstances and investment } \\
\text { objectives of the clients. Customer Account Information Form (CAIF) and Client Agreement } \\
\text { (CA) provided for clients also include additional information regarding the intermediary } \\
\text { including proprietary trading activities, businesses in which the firm is engaged, overall risk } \\
\text { profile (position limit), margin trading, principal trading with customer (counterparty exposure, } \\
\text { etc. }\end{array}$ \\
\hline Assessment & Implemented \\
\hline Comments & 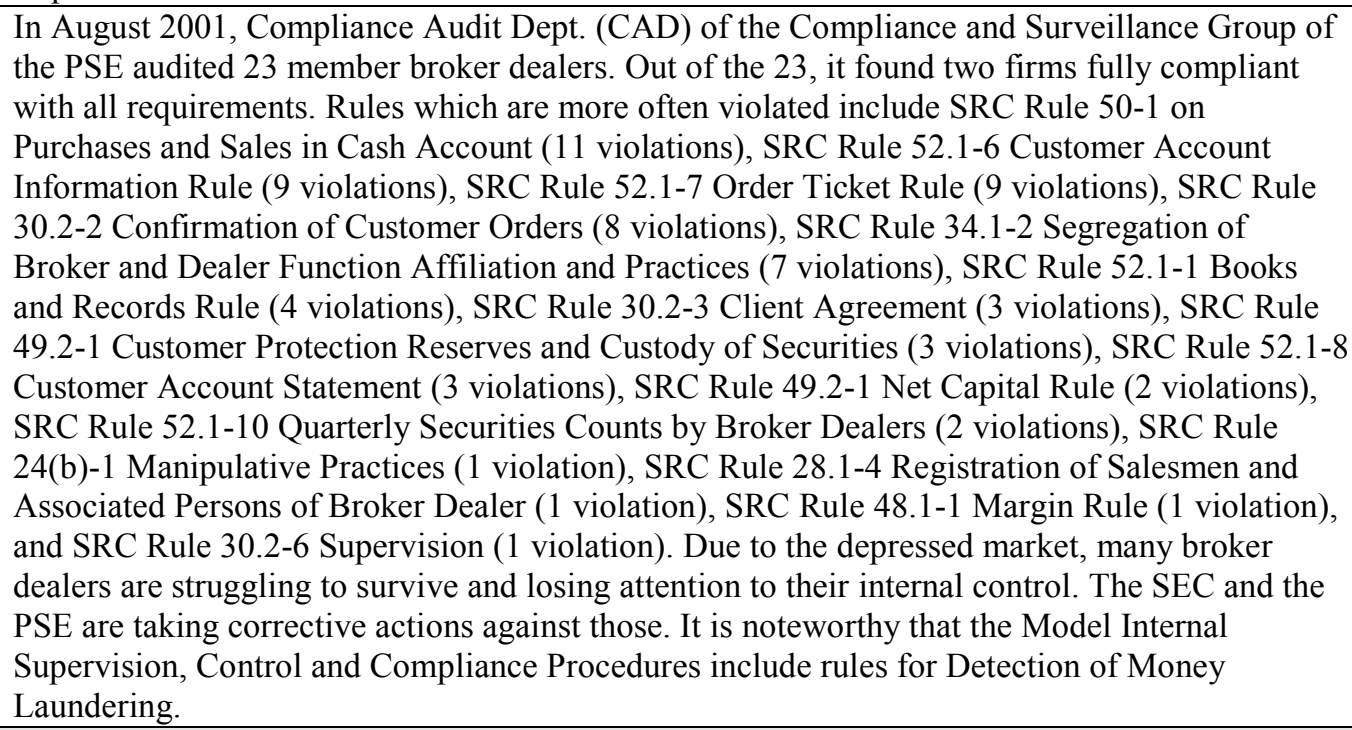 \\
\hline Principle 24. & $\begin{array}{l}\text { There should be a procedure for dealing with the failure of a market intermediary in order to } \\
\text { minimize damage and loss to investors and to contain systemic risk. }\end{array}$ \\
\hline Description & $\begin{array}{l}\text { On the basis of Section 33.1.(d) of the SRC, SRC Rule 33.2(d)-1 provides for Protection of } \\
\text { Customer Accounts in Case of Business Failure of an Exchange Member. Under the rule, an } \\
\text { Exchange is required, based on an order of the SEC, to suspend failed intermediary's } \\
\text { membership, immediately arrange for another member to take over the outstanding contracts } \\
\text { relating to securities and simultaneously notify the SEC of such suspension and take-over. The } \\
\text { Exchange is to notify customers of the failed member that their accounts have been transferred } \\
\text { to another member, and provide such customers with the opportunity to re-transfer their } \\
\text { accounts to another member of their choice. The Exchange is to settle the failed member's } \\
\text { liabilities to customers through the sale of the member's seat or trading rights, liquidation of the } \\
\text { paid up capital, etc. If there are still outstanding liabilities to the customers after such } \\
\text { settlement, the Exchange is to transfer those to the Securities Investor Protection Fund }\end{array}$ \\
\hline
\end{tabular}




\begin{tabular}{|c|c|}
\hline & $\begin{array}{l}\text { (established under Section } 36.5 \text { of the SRC), so inform the customers and advise on procedures } \\
\text { for claiming compensation for the uncovered losses. The Rules and Regulations for the } \\
\text { Implementation of the SIPF provides such procedures. } \\
\text { On the other hand, Section } 29 \text { of the SRC and SRC Rule } 29 \text { provide for Protection of Customer } \\
\text { Accounts where the SEC suspends or revokes registration of broker dealer. Under the } \\
\text { circumstance, the Exchange is to immediately arrange for another member to take over any } \\
\text { outstanding contracts relating to securities, simultaneously notify the SEC in writing of such } \\
\text { transfer and any affected customers of the fact, and provide such customers with the } \\
\text { opportunity to re-transfer their account to another broker dealer of their choice. If the } \\
\text { suspended/revoked broker dealer is not a member of an Exchange, the SEC is to notify affected } \\
\text { customers of the suspension/revocation and require that they transfer their account to another } \\
\text { broker dealer. The Net Capital Rule provides opportunities for the SEC and the Exchange to } \\
\text { monitor the solvency of intermediaries and intervene before any intermediary become fully } \\
\text { insolvent. The SRC provides full autonomy for an Exchange to act on member's insolvency } \\
\text { under the supervision of the SEC. }\end{array}$ \\
\hline Assessment & Implemented \\
\hline Comments & $\begin{array}{l}\text { The SIPF is funded with monthly member contributions of P10,000 plus one } 0.0002 \text { percent of } \\
\text { each member's gross trading volume. The SIPF is to cover up to P } 100,000 \text { per customer. The } \\
\text { SIPF has so far not been mobilized to act on a broker dealer insolvency. }\end{array}$ \\
\hline Principle 25. & $\begin{array}{l}\text { The establishment of trading systems including securities exchanges should be subject to } \\
\text { regulatory authorization and oversight. }\end{array}$ \\
\hline Description & 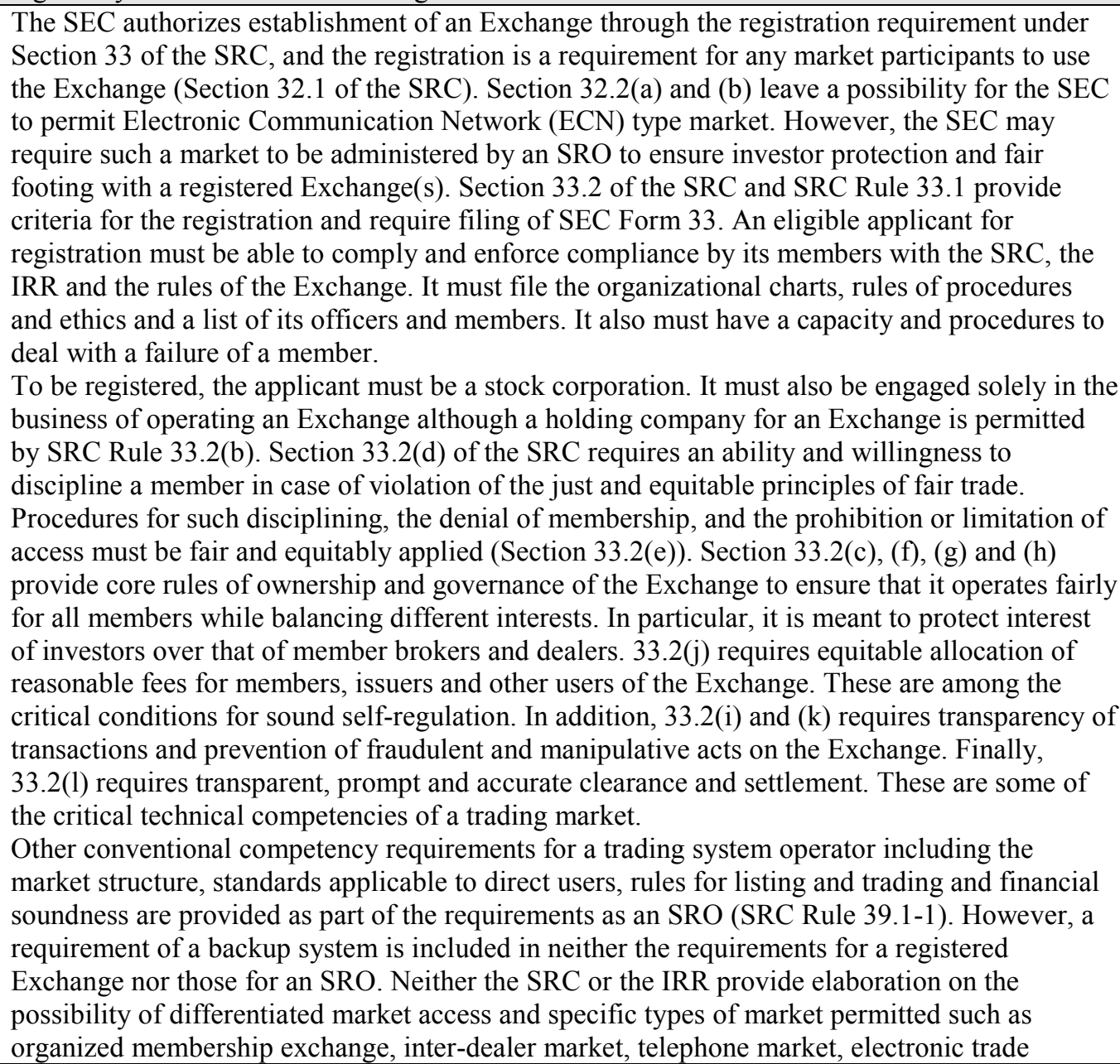 \\
\hline
\end{tabular}




\begin{tabular}{|c|c|}
\hline & 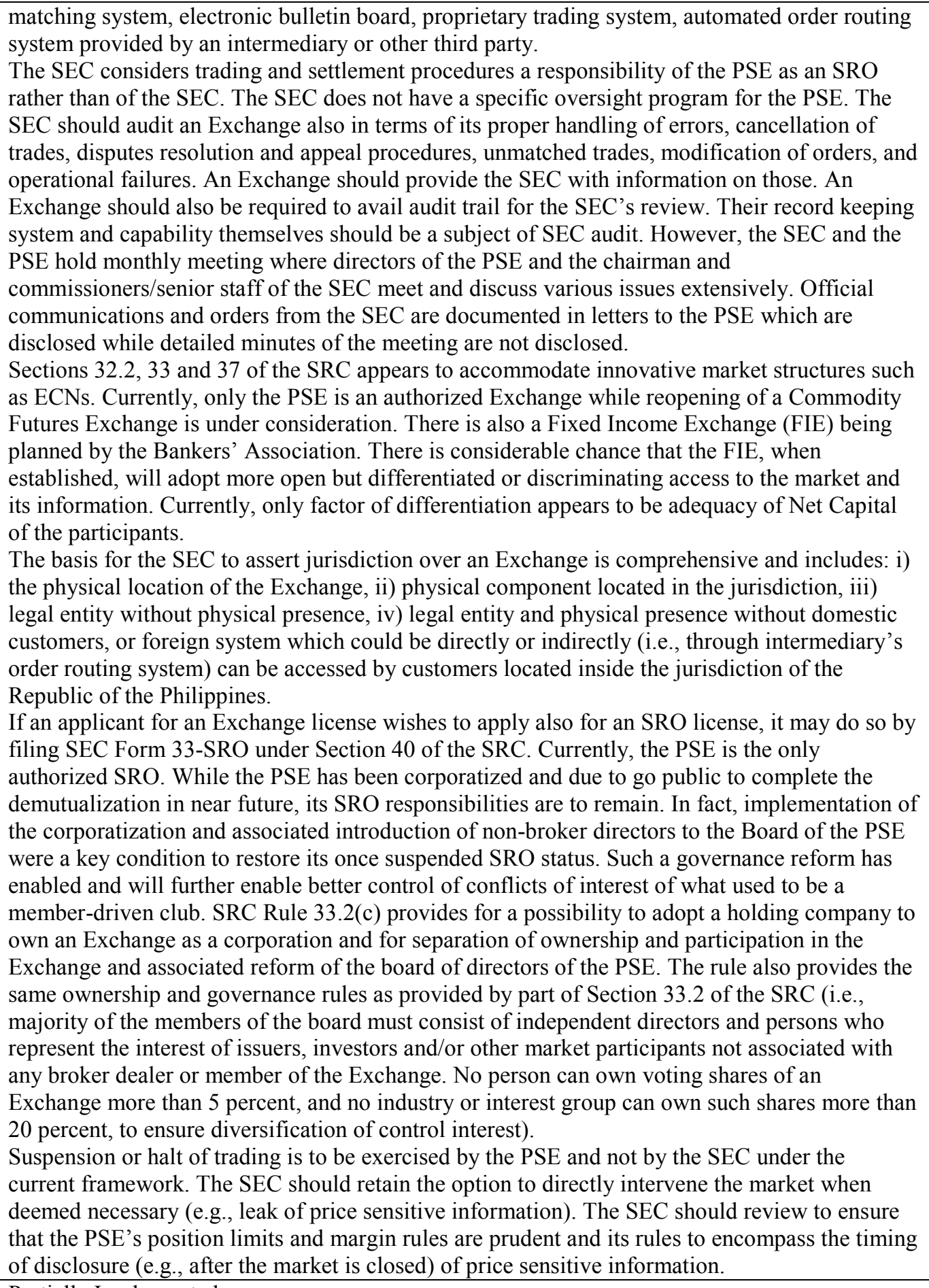 \\
\hline Assessment & Partially Implemented \\
\hline Comments & $\begin{array}{l}\text { Modern market regulation requires consideration of complex policy issues. It is not clear } \\
\text { whether the current regulatory framework for an Exchange is a result of such consideration; i.e., } \\
\text { there are some unconventional but sound measures and some other unconventional and unsound } \\
\text { measures, aside from conventional ones. Generally, the SEC's control over the PSE as a trading } \\
\text { market is somewhat loose while that over it as an SRO is tight. For example, the requirements }\end{array}$ \\
\hline
\end{tabular}




\begin{tabular}{|c|c|}
\hline & 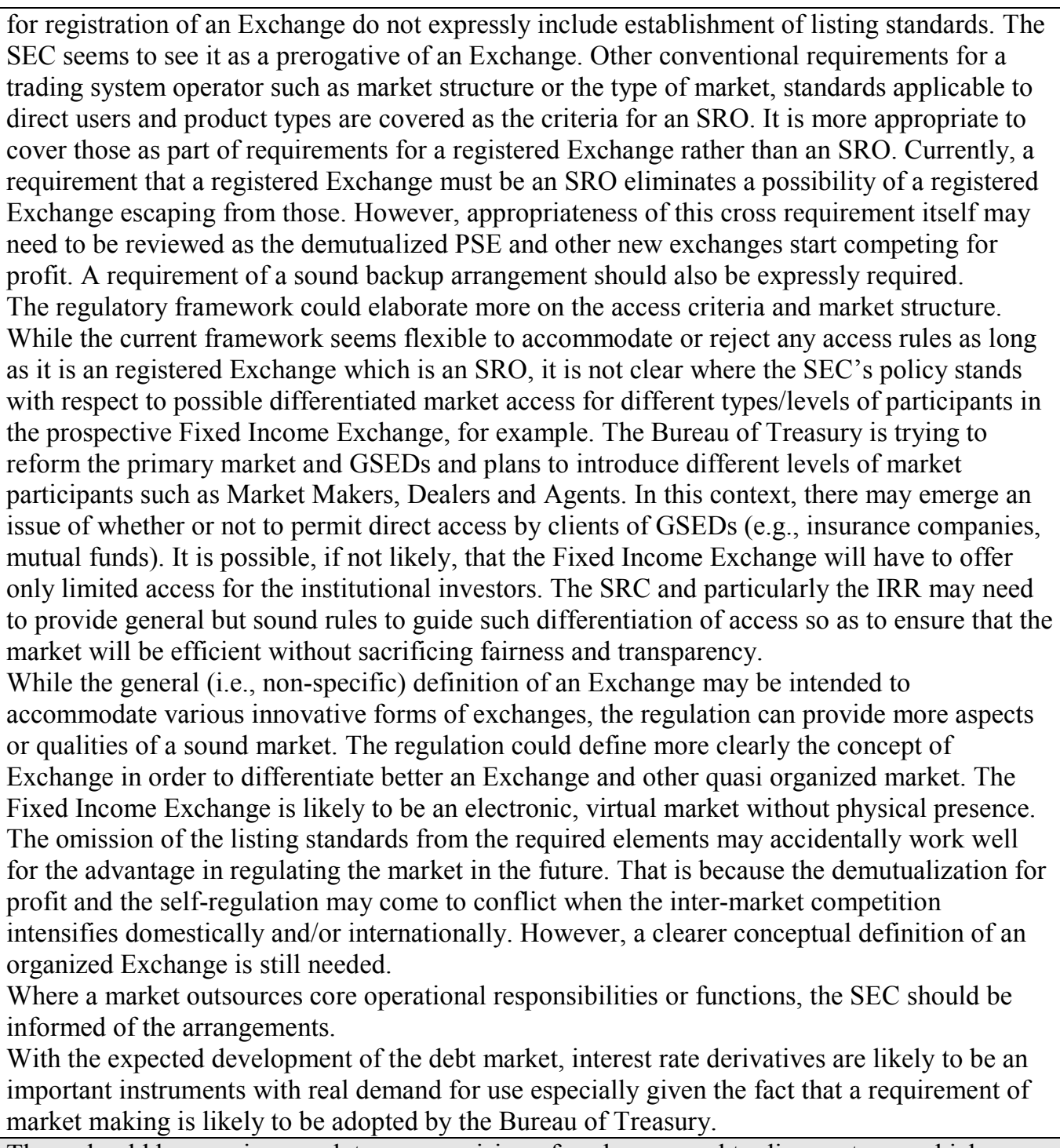 \\
\hline Principle 26. & $\begin{array}{l}\text { There should be ongoing regulatory supervision of exchanges and trading systems, which } \\
\text { should aim to ensure that the integrity of trading is maintained through fair and equitable rules } \\
\text { that strike an appropriate balance between the demands of different market participants. }\end{array}$ \\
\hline Description & $\begin{array}{l}\text { The SEC conducts continuous oversight over the PSE. All trading rules of the Exchange are } \\
\text { reviewed by the SEC for consistency with the SRC. The registration criterion (Section 33.2.(d) } \\
\text { and corresponding Rules) requires a registered Exchange to enforce its rules onto the members. } \\
\text { The PSE has reconfigured its MakTrade to ensure implementation of the Customer First Rule } \\
\text { for execution of trades, which is a commendable achievement. The SEC has reviewed the rules } \\
\text { and the system and approved it. The new system and rules allow more flexible and less } \\
\text { stringent internal control requirements for market participants without sacrificing investor } \\
\text { protection. } \\
\text { The SEC currently does not have monitoring access to the PSE's surveillance system. However, } \\
\text { the SEC has recently approved the Rules of the Exchange governing unusual trading conditions, } \\
\text { and the PSE is currently upgrading the surveillance system subject to approval by the SEC. The } \\
\text { existing system is arbitrary and inadequate (i.e., only price band and only one arbitrary price } \\
\text { band, i.e., } 50 \text { percent ceiling and } 40 \text { percent floor, for all securities to flag abnormal movements } \\
\text { in the market). The PSE is working on establishing a unique price band for each issuer/class of }\end{array}$ \\
\hline
\end{tabular}




\begin{tabular}{|c|c|}
\hline & $\begin{array}{l}\text { securities. The new system is also expected to be able to flag trade concentration among the } \\
\text { market participants, accumulation of positions, volume as well as price movements including } \\
\text { combined movements, etc. The new system and rules should provide the Exchange more } \\
\text { flexibility to respond to unusual situations. The SEC should be provided with a terminal to } \\
\text { monitor not only the market activities but also the PSE's surveillance activities. } \\
\text { The SEC does not have clear authority to re-examine or withdraw registration of an exchange. } \\
\text { Its authority to modify rules or order a registered Exchange to take particular actions is also not } \\
\text { clear once it has registered it. }\end{array}$ \\
\hline Assessment & Partially Implemented \\
\hline Comments & $\begin{array}{l}\text { The SEC's oversight authority over the PSE is limited and inadequate. More generally, the SEC } \\
\text { should gain more control in authorizing and supervising an Exchange when there will emerge } \\
\text { more than one exchange competing for profit. When new exchanges with different trading } \\
\text { algorism and market structure emerge, different surveillance procedures will have to be } \\
\text { developed for those markets. }\end{array}$ \\
\hline Principle 27. & Regulation should promote transparency of trading. \\
\hline Description & $\begin{array}{l}\text { Section 33.2(i) generally but expressly requires the transparency of transactions as part of the } \\
\text { registration requirements for an Exchange. The SRC and the IRR and most PSE rules promote } \\
\text { public disclosure of information about trading on a real time basis. Moreover, there have been a } \\
\text { number of information vendors which have officially interlinked with the PSE trading system } \\
\text { for the purpose of providing "pre, post and real time" trading information. Some of these could } \\
\text { even provide an integrated "front end" and "back room" services. The PSE is currently } \\
\text { developing an "automated disclosure" system which could be accessed on-line by interested } \\
\text { parties. Lack of funding has slowed its development. The system is expected in } 2002 \text {. }\end{array}$ \\
\hline Assessment & Implemented \\
\hline Comments & $\begin{array}{l}\text { While the price transparency of the current PSE system is adequate, there should be more } \\
\text { specific rules of transparency which differently structured markets can adopt. For example, pre- } \\
\text { trade price information should be accessed equally by all direct participants of an Exchange. } \\
\text { However, the market should provide pre-trade anonymity with regard to the identify of the } \\
\text { investors or intermediaries, while the market operator and the SEC should have access to the } \\
\text { pre-trade information on the identity of the market participants for the purpose of surveillance. } \\
\text { On the other hand, post trade price and volume information should be available widely for the } \\
\text { public. Etc. }\end{array}$ \\
\hline Principle 28. & $\begin{array}{l}\text { Regulation should be designed to detect and deter manipulation and other unfair trading } \\
\text { practices. }\end{array}$ \\
\hline Description & $\begin{array}{l}\text { Section } 24 \text { of the SRC provides prohibition of manipulative practices (market cornering, } \\
\text { misleading statements, etc.). SRC Rule } 24.1(\mathrm{~b})-1 \text { substantiates the prohibition with further } \\
\text { details. Section } 26 \text { of the SRC expressly prohibits fraudulent transactions. SRC } 32.2(\mathrm{a})-2 \\
\text { provides broker's duty of Best Execution for customers. The SEC issued Customer First Rule to } \\
\text { prevent front running. The PSE reconfigured its MakTrade to automatically ensure } \\
\text { implementation of the Customer First Rule. Section } 33.2(\mathrm{k}) \text { of the SRC generally but expressly } \\
\text { requires a registered Exchange to prevent fraudulent and manipulative acts and practices and } \\
\text { promote just and equitable principles of trade. } \\
\text { The SEC has administrative powers to obtain compliance with the SRC and other laws it } \\
\text { administer. Section } 54 \text { provides powers for the SEC to impose administrative sanctions against } \\
\text { manipulative and fraudulent practices. Such sanctions include disqualification of officers, fine, } \\
\text { etc. Sections } 58 \text { and } 59 \text { of the SRC provide Civil Liability for Fraud in Securities Transactions } \\
\text { and for Manipulation, respectively. Section } 61 \text { provides Civil Liability on Insider Trading. } \\
\text { Section } 64 \text { of the SRC provides the SEC with a power to issue Cease and Desist orders to halt } \\
\text { or suspend trading. The surveillance function of the PSE can be outsourced (i.e., no legal } \\
\text { restriction). However, the PSE directly surveys its market. The SEC currently uses Technistock, } \\
\text { a market-related database system operated by a private information vendor, to survey the } \\
\text { market movements, activities and conducts. The SEC has sufficient power to compel inspection } \\
\text { of systems within the limit of Constitutional Rights. In addition to the reporting requirements }\end{array}$ \\
\hline
\end{tabular}




\begin{tabular}{|c|c|}
\hline & $\begin{array}{l}\text { and listing criteria, the PSE also imposes market position limits and requires settlement price. } \\
\text { The SEC can also force broker deals to liquidate positions. .The SEC and the PSE as the SRO } \\
\text { have information sharing arrangements, arrangements to provide assistance in inspection, } \\
\text { investigation and surveillance. }\end{array}$ \\
\hline Assessment & Partially implemented \\
\hline Comments & $\begin{array}{l}\text { The legal and regulatory prohibitions, administrative powers and civil liabilities are sound. The } \\
\text { new market surveillance system of the PSE which is being tested currently and soon to be } \\
\text { introduced reflects significant improvements to the existing system. However, the SEC needs to } \\
\text { gain direct monitoring access to it. The SEC should have a clearly defined power to require the } \\
\text { PSE and any prospective trading market operators to provide it with monitoring access to the } \\
\text { surveillance systems and use the power. }\end{array}$ \\
\hline Principle 29. & $\begin{array}{l}\text { Regulation should aim to ensure the proper management of large exposures, default risk and } \\
\text { market disruption. }\end{array}$ \\
\hline Description & $\begin{array}{l}\text { The PSE (its Compliance and Surveillance Group) as an SRO is required to maintain fair and } \\
\text { orderly market (Section } 40.3(\mathrm{c}) \text { ), } 40.4(\mathrm{~b}) \text { ). The SEC also has a power to require the PSE as an } \\
\text { SRO to maintain order in the market. Section } 42.2 \text { (f) provides that a Clearing Agency must } \\
\text { establish and oversee a fund to guarantee the prompt and accurate clearance and settlement of } \\
\text { transactions executed on an Exchange with contributions from members, based on their trading } \\
\text { volume and a relevant percentage of the daily exposure of the four largest trading brokers. } \\
\text { The Securities Clearing Corporation of the Philippines (SCCP), to which all broker dealers are } \\
\text { members, has a "fails management system" wherein any undelivered shares will have to be } \\
\text { bought by making use of the Trade Clearing and Guarantee Fund (TCGF). In the same manner, } \\
\text { any unpaid shares be sold in the market to close out the exposure. Incidental cost incurred is } \\
\text { charged to the defaulting broker. } \\
\text { There is also a "credit ring agreement" between the SCCP and its participants wherein the latter } \\
\text { agree that they will contribute should the TCFG be insufficient to cover the deficiency incurred. } \\
\text { Likewise, the SCCP has also installed other risk management measures such as: a) early } \\
\text { settlement mechanism for volatile issues and/or brokers who are at risk, and b) brokers have the } \\
\text { option to pay their obligations or deliver their shares ahead of settlement date to cover their } \\
\text { negative market exposure. SCCP is required to report any breach or potential breach of its rules } \\
\text { and material financial difficulty of its member immediately to the SEC. All these rules and } \\
\text { arrangements of the SCCP are public information. } \\
\text { Registered market participants and PSE members are required to comply with Margin Rule } \\
\text { (SRC Rule } 48.1-1 \text { ) and Net Capital Rule (SRC Rule } 49.1-1 \text { ) which are set by the SEC on the } \\
\text { basis of Sections } 48 \text { and } 50 \text { and } 49 \text { of the SRC, respectively. If a market participant does not } \\
\text { make information on its exposure available, it can be imposed limitations on future trading, } \\
\text { required to liquidate the position, revoked of trading privilege, or suspended from trading. } \\
\text { Stock lending and borrowing is permitted based on the SB \& L Rules of the PSE. }\end{array}$ \\
\hline Assessment & Implemented \\
\hline Comments & $\begin{array}{l}\text { The SEC intends to soon amend requirements to increase the size of broker contributions to the } \\
\text { Trade Clearing and Guarantee Fund (TCGF) to adequately reflect risk exposure. Improvements } \\
\text { are needed also in short-selling, netting, securities borrowing, regulation and Securities Investor } \\
\text { Protection Fund (SIPF) }\end{array}$ \\
\hline Principle 30. & $\begin{array}{l}\text { Systems for clearing and settlement of securities transactions should be subject to regulatory } \\
\text { oversight, and designed to ensure that they are fair, effective and efficient and that they reduce } \\
\text { systemic risk. }\end{array}$ \\
\hline Description & $\begin{array}{l}\text { The legal infrastructure for effectively regulating the clearance and settlement of securities and } \\
\text { the reduction of systemic risk is provided for in rules adopted under the SRC, IRR and in } \\
\text { related SEC Orders. Section } 42 \text { of the SRC and SRC Rule } 42-1 \text { stipulates a requirement of } \\
\text { registration of Clearing Agencies (SEC Form } 42-C A \text { ). Rules and Operating Procedures of the } \\
\text { SCCP are approved by the SEC under the SRC and the IRR and available to the market } \\
\text { participants. SRC Rule } 40.5 .1 \text { provides the SEC's powers over Clearing Agencies as well as }\end{array}$ \\
\hline
\end{tabular}




\begin{tabular}{|c|c|}
\hline & 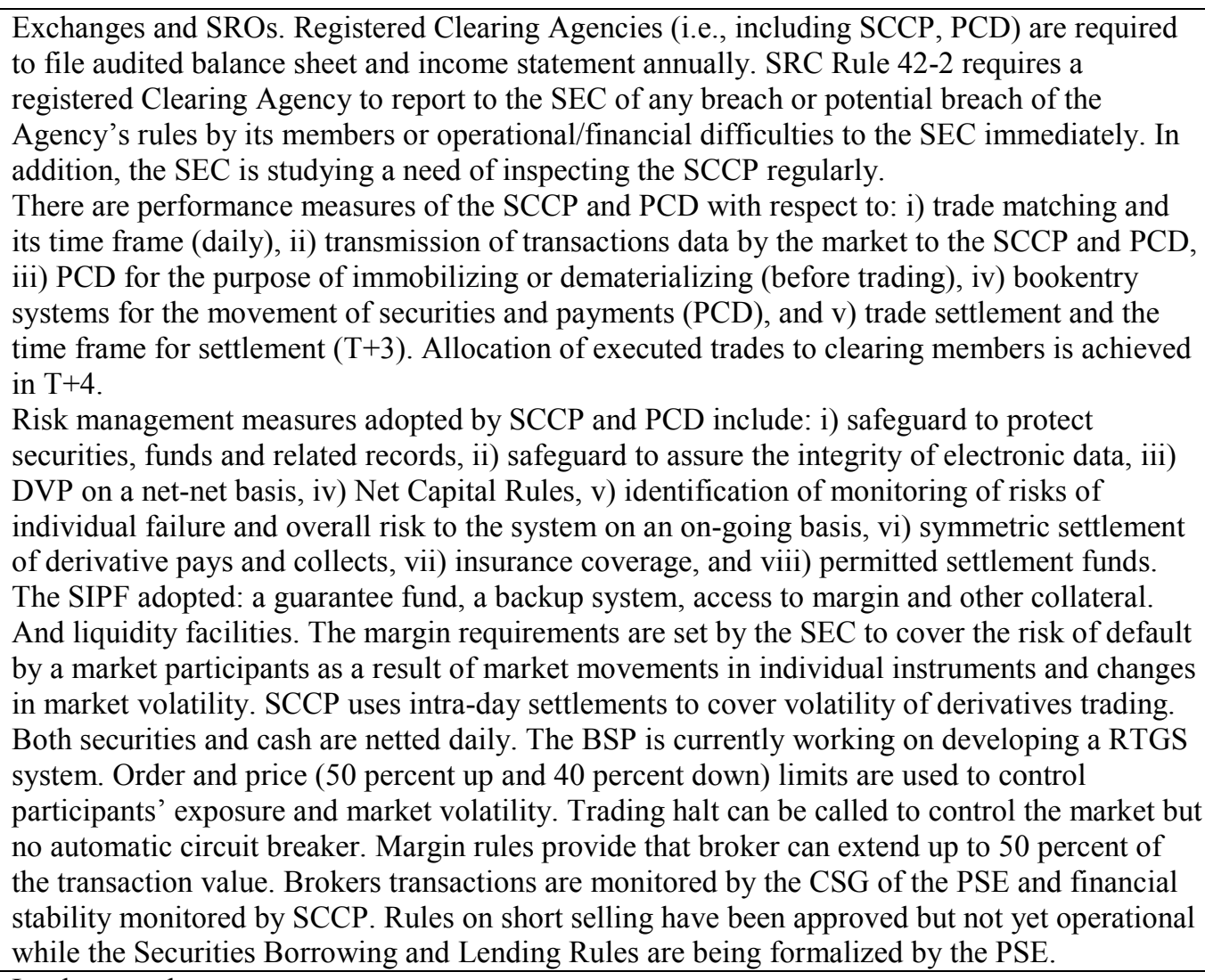 \\
\hline Assessment & Implemented \\
\hline Comments & $\begin{array}{l}\text { The SEC recently amended requirements to increase the size of broker contributions to the } \\
\text { Trade Clearing and Guarantee Fund (TCGF) to adequately reflect risk exposure. Improvements } \\
\text { are needed also in short-selling, netting, securities borrowing, regulation and the SIPF. } \\
\text { Impediments have been resistance of the brokers many of which are struggling to survive in the } \\
\text { current depressed market. The SEC is working with the brokers to educate them on the need to } \\
\text { incorporate international best practice standards and slowly convincing them to support the } \\
\text { SEC's efforts. The SEC is slowly but surely winning the broker dealers to its side. } \\
\text { The SEC is closely working with the PSE and the brokers to educate them on the need for } \\
\text { centralized clearing and settlement, the importance of the TCGF and the rule of the SCCP. In } \\
\text { addition, the SRC codified the rule and regulation of clearing agencies and the TCGF and } \\
\text { provided the SEC with additional oversight powers. Last } 17 \text { April } 2000 \text {, SCCP started imposing } \\
\text { sanctions and collecting fines and penalties for settlement violations while on } 01 \text { May } 2000 \text {, the } \\
\text { SCCP commenced a Mark to Market Collateralization System. The SEC hopes by the end of } \\
\text { September, the SCCP shall have executed a "credit ring agreement" with all its participants. }\end{array}$ \\
\hline
\end{tabular}




\section{Table of observance of individual principles}

Table 3. Compliance with the IOSCO Objectives and Principles of Securities Regulation

\begin{tabular}{|c|c|c|c|c|c|}
\hline \multirow{2}{*}{ Principle } & \multicolumn{4}{|c|}{ Gradings } & \multirow{2}{*}{ Comments and Corrective Actions } \\
\hline & $\mathrm{I}^{\underline{1}}$ & $\mathrm{PI}^{2 /}$ & $\mathrm{NI}^{3 /}$ & $\mathrm{NA}^{4-}$ & \\
\hline $\begin{array}{l}\text { 1. The responsibilities of the regulator should be } \\
\text { clear and objectively stated. }\end{array}$ & $\mathrm{X}$ & & & & $\begin{array}{l}\text { The MOA together with the SRC and the } \\
\text { New Central Bank Act filled loopholes, } \\
\text { rationalized the responsibility sharing } \\
\text { arrangements and made those clearer to } \\
\text { the regulated. The possible transfer of the } \\
\text { responsibility to regulate and supervise } \\
\text { Pre-Need Plans to the Insurance } \\
\text { Supervisory Commission, if and when } \\
\text { occurs, should further rationalize the } \\
\text { responsibilities of the SEC. }\end{array}$ \\
\hline $\begin{array}{l}\text { 2. The regulator should be operationally } \\
\text { independent and accountable in the exercise of } \\
\text { its functions and powers. }\end{array}$ & $\mathrm{X}$ & & & & $\begin{array}{l}\text { While the SEC operates independently } \\
\text { and accountably in practice, the practice } \\
\text { and the underlying laws could be made } \\
\text { more consistent with each other. }\end{array}$ \\
\hline $\begin{array}{l}\text { 3. The regulator should have adequate powers, } \\
\text { proper resources and the capacity to perform its } \\
\text { functions and exercise its powers. }\end{array}$ & $\mathrm{X}$ & & & & $\begin{array}{l}\text { Interpretation of the SRC to provide } \\
\text { adequate resources for the SEC has been } \\
\text { confirmed. }\end{array}$ \\
\hline $\begin{array}{l}\text { 4. The regulator should adopt clear and } \\
\text { consistent regulatory processes. }\end{array}$ & $X$ & & & & \\
\hline $\begin{array}{l}\text { 5. The staff of the regulator should observe the } \\
\text { highest professional standards including } \\
\text { appropriate standards of confidentiality. }\end{array}$ & $\mathrm{X}$ & & & & $\begin{array}{l}\text { Key elements to ensure highest } \\
\text { professional conducts of the staff have } \\
\text { been provided in both the SRC and the } \\
\text { IRR. The combination of the indemnity } \\
\text { and the enhanced salary also provide } \\
\text { strong incentives to comply. }\end{array}$ \\
\hline $\begin{array}{l}\text { 6. The regulatory regime should make } \\
\text { appropriate use of Self-Regulatory Organizations } \\
\text { (SROs) that exercise some direct oversight } \\
\text { responsibility for their respective areas of } \\
\text { competence, and to the extent appropriate to the } \\
\text { size and complexity of the markets. }\end{array}$ & & $\mathrm{X}$ & & & $\begin{array}{l}\text { The framework created by the SRC is } \\
\text { sound. Diversification of the ownership } \\
\text { of the PSE is awaited as the final step to } \\
\text { complete full implementation. } \\
\text { Establishment of the CFE and the FIE } \\
\text { may call for a review of the self- } \\
\text { regulatory policy, however. }\end{array}$ \\
\hline $\begin{array}{l}\text { 7. SROs should be subject to the oversight of the } \\
\text { regulator and should observe standards of } \\
\text { fairness and confidentiality when exercising } \\
\text { powers and delegated responsibilities. }\end{array}$ & $\mathrm{X}$ & & & & $\begin{array}{l}\text { The SEC is encouraged to develop a } \\
\text { specific supervisory program for the PSE } \\
\text { and forthcoming SROs. }\end{array}$ \\
\hline $\begin{array}{l}\text { 8. The regulator should have comprehensive } \\
\text { inspection, investigation and surveillance } \\
\text { powers. }\end{array}$ & $\mathrm{X}$ & & & & \\
\hline $\begin{array}{l}\text { 9. The regulator should have comprehensive } \\
\text { enforcement powers. }\end{array}$ & $\mathrm{X}$ & & & & \\
\hline
\end{tabular}




\begin{tabular}{|c|c|c|c|}
\hline $\begin{array}{l}\text { 10. The regulatory system should ensure an } \\
\text { effective and credible use of inspection, } \\
\text { investigation, surveillance and enforcement } \\
\text { powers and implementation of an effective } \\
\text { compliance program. }\end{array}$ & & $\mathrm{X}$ & $\begin{array}{l}\text { The SEC is in the process to complete the } \\
\text { staffing and MIS capacity building to } \\
\text { fully implement the SRC which } \\
\text { emphasizes enforcement. The assessment } \\
\text { is near "Implemented." }\end{array}$ \\
\hline $\begin{array}{l}\text { 11. The regulator should have authority to share } \\
\text { both public and non-public information with } \\
\text { domestic and foreign counterparts. }\end{array}$ & $\mathrm{X}$ & & \\
\hline $\begin{array}{l}\text { 12. Regulators should establish information } \\
\text { sharing mechanisms that set out when and how } \\
\text { they will share both public and non-public } \\
\text { information with their domestic and foreign } \\
\text { counterparts. }\end{array}$ & & $\mathrm{X}$ & $\begin{array}{l}\text { Finalization of the MOU with } \\
\text { BAPEPAM and working relationships } \\
\text { with the PSE is awaited. The assessment } \\
\text { is near "Implemented". }\end{array}$ \\
\hline $\begin{array}{l}\text { 13. The regulatory system should allow for } \\
\text { assistance to be provided to foreign regulators } \\
\text { who need to make inquiries in the discharge of } \\
\text { their functions and exercise of their powers. }\end{array}$ & $\mathrm{X}$ & & \\
\hline $\begin{array}{l}\text { 14. There should be full, accurate and timely } \\
\text { disclosure of financial results and other } \\
\text { information that is material to investors' } \\
\text { decisions. }\end{array}$ & $\mathrm{X}$ & & \\
\hline $\begin{array}{l}\text { 15. Holders of securities in a company should be } \\
\text { treated in a fair and equitable manner. }\end{array}$ & $\mathrm{X}$ & & $\begin{array}{l}\text { Code of Corporate Governance has } \\
\text { recently been issued and compliance with } \\
\text { it has been mandated. }\end{array}$ \\
\hline $\begin{array}{l}\text { 16. Accounting and auditing standards should be } \\
\text { of a high and internationally acceptable quality. }\end{array}$ & $\mathrm{X}$ & & \\
\hline $\begin{array}{l}\text { 17. The regulatory system should set standards } \\
\text { for the eligibility and the regulation of those who } \\
\text { wish to market or operate a collective investment } \\
\text { scheme. }\end{array}$ & & $\mathrm{X}$ & $\begin{array}{l}\text { Passage of RICA is awaited to bring } \\
\text { investment advisors under the SEC } \\
\text { regulation. }\end{array}$ \\
\hline $\begin{array}{l}\text { 18. The regulatory system should provide for } \\
\text { rules governing the legal form and structure of } \\
\text { collective investment schemes and the } \\
\text { segregation and protection of client assets. }\end{array}$ & & $X$ & $\begin{array}{l}\text { Passage of RICA is awaited to strengthen } \\
\text { regulation of related party transactions. } \\
\text { Passage of RICA is awaited to provide } \\
\text { rules for segregation of clients' assets and } \\
\text { delegation of functions. }\end{array}$ \\
\hline $\begin{array}{l}\text { 19. Regulation should require disclosure, as set } \\
\text { forth under the principles for issuers, which is } \\
\text { necessary to evaluate the suitability of a } \\
\text { collective investment scheme for a particular } \\
\text { investor and the value of the investor's interest } \\
\text { in the scheme. }\end{array}$ & & $\mathrm{X}$ & $\begin{array}{l}\text { Passage of RICA is awaited to provide } \\
\text { for requirements for disclosure of } \\
\text { investment company-specific information } \\
\text { and powers to enforce the disclosure } \\
\text { requirements. }\end{array}$ \\
\hline $\begin{array}{l}\text { 20. Regulation should ensure that there is a } \\
\text { proper and disclosed basis for asset valuation } \\
\text { and the pricing and the redemption of units in a } \\
\text { collective investment scheme. }\end{array}$ & & $\mathrm{X}$ & $\begin{array}{l}\text { Development of standards for net asset } \\
\text { value calculation and accounting for } \\
\text { amortization is awaited. Requirements } \\
\text { for disclosure of the value of interests in } \\
\text { a CIS, capacity to enforce disclosure } \\
\text { requirement, and pricing and redemption } \\
\text { of units need to be improved. Role of } \\
\text { custodians may be strengthened, and } \\
\text { circumstances under which closed end } \\
\text { funds may repurchase its shares may be } \\
\text { specified. }\end{array}$ \\
\hline
\end{tabular}




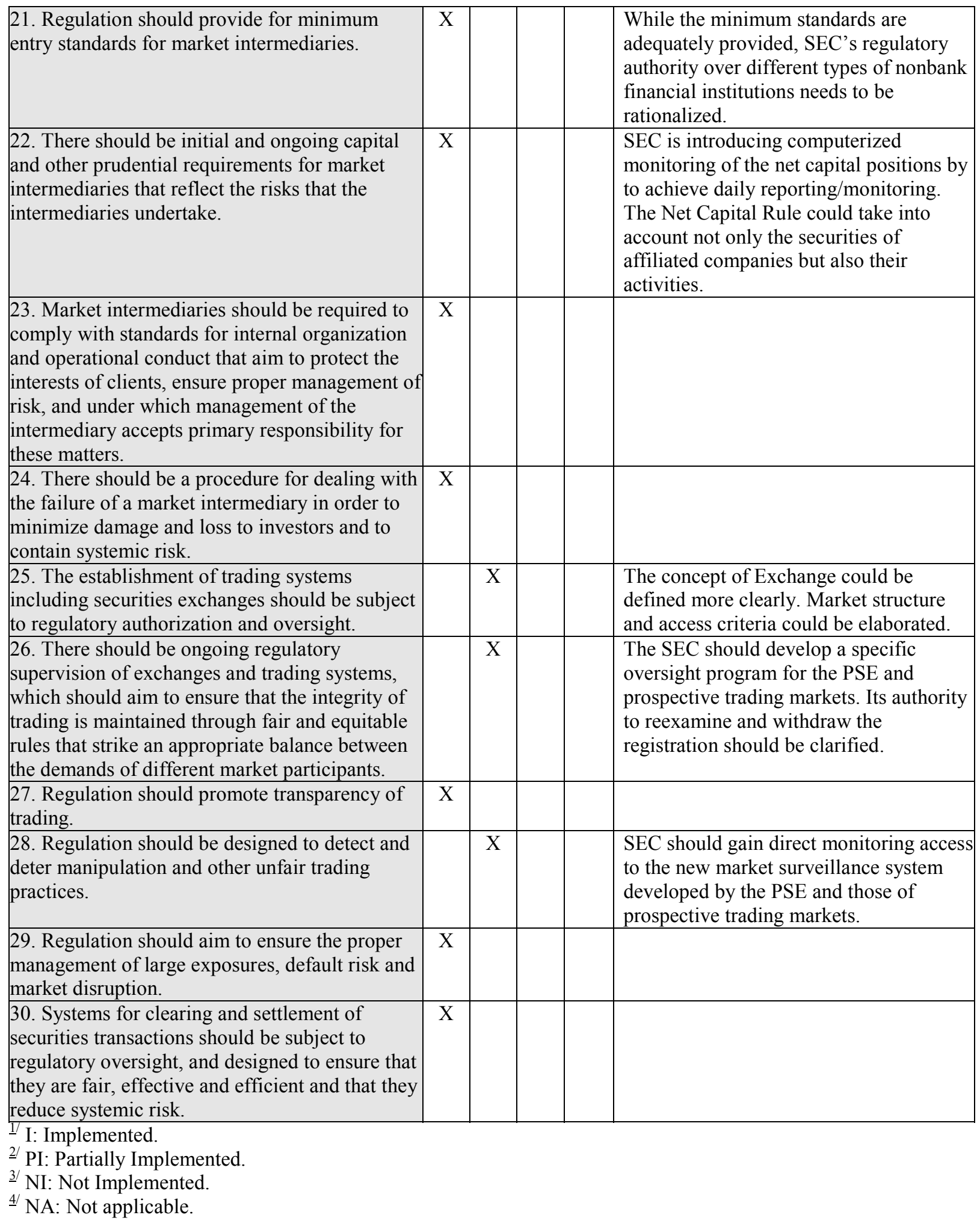




\section{RECOMmended Plan of ACtion ANd SuPERVisory Response to the AsSessment}

\section{A. Supervisory Response}

37. Principles relating to the regulators (CPs 1-5). The SEC shall intensify the inhouse training of its staff to enhance their skills on market surveillance, investigation and enforcement. The full computerization of our data is also going on. The Manual of Operations and Procedures for the staff is being reviewed and revised for simplicity and clarity.

38. Principles of self-regulation (CPs 6-7). The listing of the PSE is the second phase of demutualization. The Board is only waiting for the right time to go public. In the meantime, to implement the provisions of the SRC on the 20 percent ownership cap of broker dealers, the SEC has directed the PSE to offer its shares to institutional investors and has likewise suggested the ADB and the IFC to consider taking a stake in the Exchange. Discussions on ensuring the independence of the Compliance and Surveillance Group of the PSE (CSG-PSE) is being undertaken by the Market Regulation Department of the SEC. Although the PSE-CSG has already been incorporated as separate entity from that the of the PSE, the PSE President has requested for the delay of the operationalization of the CSG-PSE as an independent SRO as the PSE tries to study ways of achieving full independence of the CSG while remaining part of the PSE organizational structure.

39. Principles for the enforcement of securities regulations (CPs 8-10). On April 16, 2002, the SEC has operationalized its on-line filing for the registration of companies. Thereafter, reportorial requirements shall be filed electronically. Even the net-capital requirements from broker dealers shall be electronically fined and analyzed by our MRD.

40. Principles for cooperation in regulation (CPs 11-13). The SEC recently acquired a favorable endorsement from the Department of Foreign Affairs (DFA) to enter into MOU with its counterparts. It is currently finalizing an MOU with Indonesia's BAPEPAM. Similar agreements with other regulators are being considered.

41. Principles for issuers (CPs 14-16). The SEC has recently approved the Code of Corporate Governance which shall be "mandatory" for all corporations whose securities are registered or listed, corporations which are grantees of permits/licenses and secondary franchise from the SEC and public companies.

42. Principles for collective investment schemes (CPs 17-20). The SEC hopes that the Revised Investment Company Act will soon be passed into law by this year. While the SEC is ready to appear any time before Congressional hearings, it has no control of what the priority Bills and schedule of our lawmakers are.

43. Principles for market intermediaries (CPS 21-24). The system to monitor Net Capital of brokers dealers is now being prepared by our MIS in cooperation with our MRD. The SEC hopes before the end of the second quarter, a system for testing shall be ready. 
44. Principles for the secondary market (CPs 25-30). With the establishment and operationalization of the Fixed Income Exchange (FIE) and the revival of the Futures Exchange, the FSAP mission raised concerns that competition emerging among markets may raise doubts about credibility of their self-regulatory functions. The mission has thus suggested that the SEC provide key benchmarks through Rules and/or Orders to define what its concept of Philippine capital markets is in an environment where various exchanges compete as for-profit businesses. The SEC shall take note of this suggestion and will see to it that the mission's concerns will be properly addressed.

\section{B. Recommended Action}

45. Overall, the Philippines scores very well against the IOSCO Principles thanks to the conscious efforts having been made in the recent past. Some improvements are needed in the areas of collective investment schemes and secondary market regulation. Remaining issues in other areas are either currently being addressed or relatively minor.

Table 4. Recommended Actions to Improve Compliance with the IOSCO Objectives and Principles of Securities Regulation

\begin{tabular}{|l|l|}
\hline \multicolumn{1}{|c|}{ Subject } & \multicolumn{1}{c|}{ Recommended Action and Time-Frame } \\
\hline Principles relating to the regulator, (CPs 1-5) & $\begin{array}{l}\text { In-house training of the SEC staff to enhance their skills on } \\
\text { market surveillance, investigation and enforcement should be } \\
\text { strengthened. The Manual of Operations and Procedures for the } \\
\text { staff currently reviewed and revised may be used to develop the } \\
\text { training program. Computerization of electronic filing of } \\
\text { company registration has been introduced. Further progress with } \\
\text { computerization of the SEC's regulatory reporting and } \\
\text { monitoring is awaited. }\end{array}$ \\
\hline
\end{tabular}




\begin{tabular}{|c|c|}
\hline Principles of self-regulation (CPs 6-7) & $\begin{array}{l}\text { Diversification of the PSE's ownership away from dominance } \\
\text { by broker dealers is awaited to enhance credibility of the PSE as } \\
\text { an SRO. Measures could include private placement to } \\
\text { institutional investors of appropriate standing as well as going } \\
\text { public. Completion of a study is awaited on a possibility to } \\
\text { retain the Compliance and Surveillance Group of the PSE (CSG- } \\
\text { PSE) as part of the PSE while ensuring its independence. }\end{array}$ \\
\hline $\begin{array}{l}\text { Principles for the enforcement of securities } \\
\text { regulation (CPs } 8-10)\end{array}$ & $\begin{array}{l}\text { Completion of the on-going series of computerization of the data } \\
\text { failing, management and analysis at the SEC is awaited to avail } \\
\text { more human resources for enforcement activities and support } \\
\text { effective enforcement with accurate, updated information which } \\
\text { is readily retrievable and analyzable. }\end{array}$ \\
\hline $\begin{array}{l}\text { Principles for cooperation in regulation (CPs 11- } \\
\text { 13) }\end{array}$ & $\begin{array}{l}\text { Finalization of an MOU with Indonesia's BAPEPAM is } \\
\text { awaited. Similar agreements with other regulators are being } \\
\text { considered. }\end{array}$ \\
\hline Principles for issuers (CPs 14-16) & $\begin{array}{l}\text { Adoption of IASs should be implemented by } 2005 \text { as planned. } \\
\text { Investor education efforts should be continued. }\end{array}$ \\
\hline $\begin{array}{l}\text { Principles for collective investment schemes } \\
\text { (CPs 17-20) }\end{array}$ & $\begin{array}{l}\text { The RICA needs to be passed by the Congress as soon as } \\
\text { possible to correct the weaknesses in the existing ICA. } \\
\text { Investment advisors should be captured. Requirements for } \\
\text { segregation and valuation of assets and delegation of functions } \\
\text { should be clarified. }\end{array}$ \\
\hline $\begin{array}{l}\text { Principles for market intermediaries (CPs 21- } \\
\text { 24) }\end{array}$ & $\begin{array}{l}\text { Implementation of the electronic Net Capital reporting and } \\
\text { monitoring system for brokers dealers is awaited to enable daily } \\
\text { monitoring. }\end{array}$ \\
\hline Principles for the secondary market (CPs 25-30) & $\begin{array}{l}\text { The potentially emerging competition among the PSE, the FIE } \\
\text { and the Futures Exchange which will all be for-profit } \\
\text { corporations may undermine the credibility of self-regulation by } \\
\text { them. The SEC is encouraged to strengthen the regulation of the } \\
\text { trading market operators. It should establish a specific } \\
\text { supervision program for a trading market operator as well as an } \\
\text { SRO. SEC may wish to consider adopting a regulatory } \\
\text { framework which accommodates trading markets with or } \\
\text { without SRO functions. To do so, rationalization of } \\
\text { requirements for an Exchange or a trading system and those for } \\
\text { SRO may be necessary. }\end{array}$ \\
\hline
\end{tabular}

